$$
\text { UNIVERSIDADE DE SÃO PAULO }
$$

FACULDADE DE ZOOTECNIA E ENGENHARIA DE ALIMENTOS

\title{
GABRIELA STROZZI
}

Características produtivas, fisiológicas e bromatológicas do capim-marandu sob doses de nitrogênio e pastejo por ovinos. 
GABRIELA STROZZI

Características produtivas, fisiológicas e bromatológicas do capim-marandu sob doses de nitrogênio e pastejo por ovinos.

Versão corrigida

Dissertação apresentada à Faculdade de Zootecnia e Engenharia de Alimentos da Universidade de São Paulo, como parte dos requisitos para a obtenção do Título de Mestre em Ciências.

Área de Concentração: Qualidade e Produtividade Animal

Orientação: Prof. Dr. Valdo Rodrigues Herling 
Dados Internacionais de Catalogação na Publicação

Serviço de Biblioteca e Informação da Faculdade de Zootecnia e Engenharia de Alimentos da Universidade de São Paulo

Strozi, Gabriela
S926c Características produtivas, fisiológicas e

bromatológicas do campim-marandu sob doses de nitrogênio e pastejo por ovinos / Gabriela Strozzi.-- Pirassununga 2014 .

$71 \mathrm{f}$.

Dissertação (Mestrado) -- Faculdade de Zootecnia e Engenharia de Alimentos - Universidade de São Paulo. Departamento de Zootecnia.

Área de Concentração: Qualidade e Produtividade Animal.

Orientador: Prof. Dr. Valdo Rodrigues Herling.

1. Adubação 2. Pastagem 3. Perfilhamento. I.Título. 


\section{DEDICATÓRIA}

Á Deus por permitir em sua fé persistir em meio a tantos desafios a mim impostos.

Aos meus pais Marco e Janice por serem meus exemplos de vida me auxiliando incondicionalmente nessa caminhada.

Aos Meus Irmãos Gian e Isabella, por me ajudarem sempre, estando ao meu lado em cada momento, sendo meu esteio nas horas em que mais precisei. Mostrando o quanto a amor fraternal é importante para a o ser humano.

Ao meu companheiro Fernando, por ser mais do que companheiro, me apoiando com sua simplicidade e paciência. 


\section{AGRADECIMENTOS}

Ao meu orientador Prof. Dr. Valdo Rodrigues Herling, pela orientação, oportunidade, confiança depositada, ensinamentos, auxílio e por proporcionar todas as condições para que esse trabalho pudesse ser desenvolvido.

À FZEA/USP pela oportunidade.

A CAPES pela bolsa de Mestrado Concedida.

À FAPESP pelo auxílio à pesquisa ao processo 2010/6542 - 1.

Aos Professores do Setor de Ciências Agrárias Dr. Pedro Henrique de Cerqueira Luz e Dr. Fabricio Rossi, que auxiliaram nesse experimento.

Ao Pessoal do Laboratório de Solos, por cederem o local para a realização das análises químicas em especial ao Marcos, pela paciência, dedicação e ensinamentos nessa etapa. Aos estagiários: Natalia, Mariane e Rafael.

A eterna amiga Jessica (Angela), companheira de todos os dias, pela paciência, pelo ouvido, pelo convívio, e em especial pela amizade que chegou no momento em que eu mais precisava.

À minha amiga Vanessa, por ser literalmente minha irmã, por dividir trabalhos e conhecimentos.

Aos meus irmãos companheiros de Pós Graduação: Baiano, Damião, Fabio, João, Syeda, por ajudarem no meu enriquecimento intelectual e pessoal.

Aos Companheiros de Pós-Graduação: Celso, Fernandinha, Hugo, Liliane, Mariana, Thiago.

Aos Estagiários que tanto me ajudaram na realização do experimento: Jessica (Caramelo), Léo, Uanderson, Marina, Bob, Flávia, Barbara, entre outros.

A Todos os companheiros das Agrárias: Paulo, Manoel, Layane, que de alguma forma ajudaram na realização do experimento.

À minha cunhada Fabiana, pelo apoio moral e intelectual durante essa etapa.

A todos os meus amigos e familiares que de alguma forma torceram pelo meu sucesso. 
EPÍGRAFE

“Nunca se desespera nas mais profundas aflições de sua vida, pois das nuvens mais escuras caem águas límpidas e fecundas". 


\section{RESUMO}

STROZZI, G. Características produtivas, fisiológicas e bromatológicas do capim-marandu sob doses de nitrogênio e pastejo por ovinos. 2014. 71 fls. Dissertação (Mestrado) - Faculdade de Zootecnia e Engenharia de Alimentos, Universidade de São Paulo, Pirassununga, 2014.

Brachiaria brizantha (Hochst ex. A. Rich) Stapf apresenta boa adaptação às condições edafoclimáticas brasileiras e é muito utilizada como planta forrageira em pastagem na produção de bovinos. Apesar de seu potencial na produção de ovinos, ainda são necessárias novas investigações para aperfeiçoar o seu manejo. Objetivou-se com esta pesquisa avaliar as características produtivas, fisiológicas e bromatológicas de um pasto formado por Brachiaria brizantha cv. Marandu, fertilizada com doses de nitrogênio $(N)$ e sob pastejo ovino. O delineamento experimental foi em blocos completos casualizados com 04 repetições e 05 tratamentos experimentais: 0; 90; 180; 270; $360 \mathrm{~kg}$ de N.ha ${ }^{-1}$, totalizando 20 parcelas experimentais. O método de pastejo foi o rotativo, com ciclo de pastejo de 30 dias, sendo 25 dias de descanso e 5 dias de ocupação, como forma de rebaixar o pasto à altura de resíduo de $6 \mathrm{~cm}$. As medições no pasto foram feitas a cada 3 dias em 3 ciclos de pastejo, quando se avaliou: o fluxo de tecidos, a dinâmica de perfilhamento, a produção e a composição bromatológica da planta forrageira. Para massa seca de forragem verificou-se comportamento quadrático nas doses crescentes de $\mathrm{N}$, atingindo o platô em $246 \mathrm{~kg} \mathrm{ha}^{-1}$. As variáveis taxas de senescência foliar, peso médio e densidade populacional de perfilhos não foram influenciados $(P>0,05)$ pela adubação nitrogenada enquanto que a taxa de alongamento e de aparecimento de folhas, a taxa de alongamento de colmo, o número de folhas vivas, o comprimento final de folhas foram influenciados pela adubação nitrogenada $(P<0,05)$. $O$ filocrono e a duração de vida da folha foram mais curtos na presença do $\mathrm{N}$. Em relação às características bromatológicas, o $\mathrm{N}$ afetou positivamente nos teores de FDA, FDN, e PB. Pelo manejo imposto aos pastos, a utilização do $\mathrm{N}$ teve efeito positivo nas características fisiológicas, produtivas e nutritivas do capim-marandu.

Palavras-chave: Adubação, pastagem, perfilhamento 


\begin{abstract}
STROZZI, G. Productive, physiological and chemical characteristics of Marandugrass under nitrogen and grazing by sheep. 2014. Fls 71.Dissertação (Master) - Faculty of Animal Science and Food Engineering, University of São Paulo, Pirassununga, 2014.

Brachiaria Brizantha (Hochst ex. A. Rich) Stapf is well adapted to Brazilian climatic conditions, and is widely used as a forage grass on pasture production in cattle. Despite its potential for use in the present sheep production, further research studies are still needed to optimize their management. The objective of this research was evaluate yield, physiological and chemical characteristics of a pasture of Brachiaria brizantha cv. Marandu, fertilized with nitrogen and grazing sheep. The experimental design was a randomized complete block with 04 replications and 05 experimental

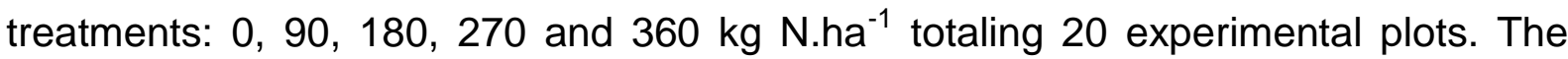
grazing method was rotating with cicle of grazing of 30 days, 25 days of rest and 5 days of occupancy to reach height of pasture residue of $6 \mathrm{~cm}$. Measurements were made in the pasture every 3 days, at,three grazing cycle evaluated. Thus analyzing the flow of plant tissue, the dynamics of tillering, yield and composition chemical of forage. For dry herbage mass there was a quadratic behavior in increasing doses. The increase of $\mathrm{N}$, there was a quadratic behavior, reaching a plateau where the best dose was $270 \mathrm{~kg} \cdot \mathrm{ha}^{-1}$. The variables leaf senescence rate, average weight and tiller density were not affected $(P>0.05)$ by use of $N$, while the variables leaf elongation rate and appearance, stem elongation rate, number of living leaves, final length of leaves were influenced by nitrogen fertilization $(\mathrm{P}<0.05)$, Phyllochron and lifetime leaves were shorter in the presence of $\mathrm{N}$. Regarding the chemical caracteristics, the presence of $\mathrm{N}$ affected positively the levels of the ADF, NDF and CP, The grazing management imposed, the use of $\mathrm{N}$ had a positive effect on the physiological, productive and chemical characteristics of Marandugrass.
\end{abstract}

Keywords: fertilization, grazing, tillering. 


\section{LISTA DE ILUSTRAÇÕES}

Figura 1- Temperatura máxima, mínima, media e pluviosidade total mensal durante o período experimental

Figura 2 - Croqui da área experimental

Figura 3 - Fotos do piquete, das parcelas experimentais, ferramentas, marcação de perfilho e medição de folhas

Figura 4 - Massa seca de forragem de Brachiaria brizantha cv. Marandu, adubada com doses de $\mathrm{N}$, considerando as médias dos ciclos de crescimento

Figura 5 - Taxa de alongamento foliar (mm.perfilho ${ }^{-1} \cdot$ dia $^{-1}$ ) de Brachiaria brizantha cv. Marandu adubada com doses de N, considerando as médias dos ciclos de crescimento

Figura 6 - Taxa de aparecimento de folha (folha.perfilho ${ }^{-1}$.dia ${ }^{-1}$ ) de Brachiaria brizantha cv. Marandu adubada com doses de N, considerando as médias dos ciclos de crescimento

Figura 7 - Filocrono (dias) de Brachiaria brizantha cv. Marandu adubada com doses de $\mathrm{N}$ considerando as médias dos ciclos de crescimento ......

Figura 8 - Número de folhas vivas de Brachiaria brizantha cv. Marandu, adubadas com doses de $\mathrm{N}$, considerando as médias dos ciclos de crescimento

Figura 9 - Duração de vida de folhas (Dias) de Brachiaria brizantha cv. Marandu, adubadas com doses de $\mathrm{N}$, considerando as médias dos ciclos de crescimentos

Figura 10 - Comprimento final de folhas $\left(\mathrm{mm}^{\text {p. perfilho }} \mathrm{H}^{-1}\right)$ de Brachiaria brizantha cv. Marandu, adubadas com doses de N, considerando as médias dos ciclos de crescimento

Figura 11 - Taxa de alongamento de colmo (mm.perfilho ${ }^{-1} \cdot$ dia $\left.^{-1}\right)$ de Brachiaria brizantha $\mathrm{cv}$. Marandu, adubadas com doses de $\mathrm{N}$, considerando as médias dos ciclos de crescimento

Figura 12 - Taxa de aparecimento de perfilhos de Brachiaria brizantha cv. Marandu, adubadas com doses de $\mathrm{N}$, considerando as médias dos ciclos de crescimento 
Figura 13 - Composição morfológica de Brachiaria brizantha cv. Marandu, adubadas com doses de $\mathrm{N}$, considerando as médias dos ciclos de crescimento

Figura 14 - Eficiência de uso do $\mathrm{N}$ por Brachiaria brizantha cv. Marandu, adubadas com doses de $\mathrm{N}$, considerando as médias dos ciclos de crescimento

Figura 15 - Teores de proteína bruta nas partes da planta de Brachiaria brizantha cv. Marandu, adubadas com doses de N considerando as médias dos ciclos de crescimento

Figura 16 - Teores de fibra em detergente neutro de planta inteira e de colmo bainha de Brachiaria brizantha cv. Marandu, adubadas com doses de $\mathrm{N}$ considerando as médias dos ciclos de crescimento

Figura 17 - Teores de fibra em detergente neutro de lâminas foliares em Brachiaria brizantha cv. Marandu adubadas com doses de N, considerando as médias dos ciclos de crescimento

Figura 18 - Teores de fibra em detergente ácido da planta, do colmo bainha e da lâmina foliar de Brachiaria brizantha cv. Marandu, adubadas com doses de $\mathrm{N}$, considerando as médias dos ciclos de crescimento 


\section{LISTA DE TABELAS}

Tabela 1 - Análise química preliminar de amostra de solo da área experimental

Tabela 2- Análise química de amostra de solo da área experimental

Tabela 3 - Médias da massa seca de forragem (kg MSF.ha-1 ${ }^{-1}$ da Brachiaria brizantha cv. Marandu, adubadas com doses de N, nos ciclos de crescimento

Tabela 4 - Médias de taxa de alongamento foliar (mm.perfilho ${ }^{-1} \cdot \mathrm{dia}^{-1}$ ), taxa de aparecimento foliar (folhas.perfilho $o^{-1} \cdot \mathrm{dia}^{-1}$ ) e filocrono (dias.folha $^{-1}$ ) de Brachiaria brizantha cv. Marandu, adubadas com doses de $\mathrm{N}$, considerando os ciclos de crescimento

Tabela 5 - Médias do número de folhas vivas, de duração de vida de folhas, de comprimento final de folhas e de taxa de alongamento de colmo de Brachiaria brizantha cv. Marandu, adubadas com doses de $\mathrm{N}$, considerando os ciclos de crescimento

Tabela 6 - Médias de densidade populacional de perfilhos, taxa de senescência foliar e taxa de aparecimento de perfilhos de Brachiaria brizantha cv. Marandu, adubadas com doses de $\mathrm{N}$, considerando os ciclos de crescimento

Tabela 7- Participação percentual média de lâmina foliar e material morto de Brachiaria brizantha cv. Marandu, adubadas com doses de N, considerando os ciclos de crescimento

Tabela 8- Médias de proteína bruta na lâmina foliar, planta inteira e colmo e bainha de Brachiaria brizantha cv. Marandu adubada com doses de $\mathrm{N}$, considerando os ciclos de crescimento

Tabela 9- Médias de fibra em detergente neutro na planta inteira e colmo e bainha de Brachiaria brizantha cv. Marandu adubada com doses de $\mathrm{N}$, considerando os ciclos de crescimento

Tabela 10- Médias de fibra em detergente ácido na lâmina foliar, planta inteira e colmo e bainha de Brachiaria brizantha cv. Marandu adubada com doses de $\mathrm{N}$, considerando os ciclos de crescimento 


\section{LISTA DE ABREVIATURA}

$\begin{array}{ll}\text { AP } & \text { Altura do pasto } \\ \text { CB } & \text { Colmo e bainha } \\ \text { CFF } & \text { Comprimento final de folha } \\ \text { DPP } & \text { Densidade populacional de perfilhos } \\ \text { DVF } & \text { Duração de vida da folha } \\ \text { EUN } & \text { Eficiência do uso do nitrogênio } \\ \text { FDA } & \text { Fibra em detergente ácido } \\ \text { FDACB\% } & \text { Porcentagem de fibra em detergente ácido no colmo e bainha } \\ \text { FDALF\% } & \text { Porcentagem de fibra em detergente ácido na lâmina foliar } \\ \text { FDAPI\% } & \text { Porcentagem de fibra em detergente ácido na planta inteira } \\ \text { FDN } & \text { Fibra em detergente neutro } \\ \text { FDNCB\% } & \text { Porcentagem de fibra em detergente neutro no colmo e bainha } \\ \text { FDNLF\% } & \text { Porcentagem de fibra em detergente neutro na lâmina foliar } \\ \text { FDNPI\% } & \text { Porcentagem de fibra em detergente neutro na planta inteira } \\ \text { Fil } & \text { Filocrono } \\ \text { IAF } & \text { Índice de área foliar } \\ \text { LF } & \text { Lâmina foliar } \\ \text { MM } & \text { Material morto } \\ \text { MS } & \text { Massa seca } \\ \text { MSF } & \text { Massa seca de forragem } \\ \text { N } & \text { Nitrogênio } \\ \text { NFV } & \text { Número de folhas vivas por perfilho } \\ \text { P } & \text { Fósforo } \\ \text { PB } & \text { Proteína bruta } \\ \text { PB\% } & \text { Porcentagem de proteína bruta } \\ \text { PBCB\% } & \text { Porcentagem de proteína bruta no colmo e bainha } \\ \text { PBLF\% } & \text { Porcentagem de proteína bruta na lâmina foliar } \\ \text { PBPI\% } & \text { Porcentagem de proteína bruta na planta inteira } \\ \text { PI } & \text { Planta inteira } \\ \text { PMP } & \text { Peso médio de perfilho } \\ \text { PMS } & \text { Produção de massa seca } \\ \text { S } & \text { Enxofre } \\ \text { TAIC } & \text { Taxa de alongamento de colmo } \\ \text { TAIF } & \text { Taxa de alongamento de folha } \\ \text { TApF } & \text { Taxa de aparecimento de folha } \\ \text { TApP } & \text { Taxa de aparecimento de perfilhos } \\ \text { TSF } & \text { Taxa de senescência foliar } \\ & \end{array}$




\section{SUMÁRIO}

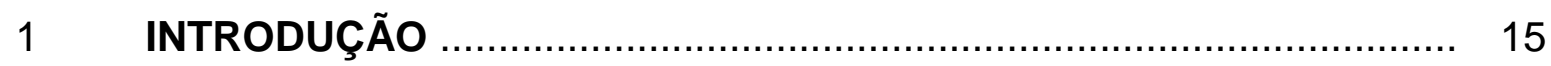

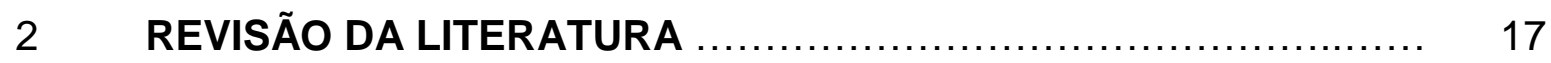

2.1 A ADUBAÇÃO NITROGENADA E A PRODUÇÃO DE FORRAGEM ... 17

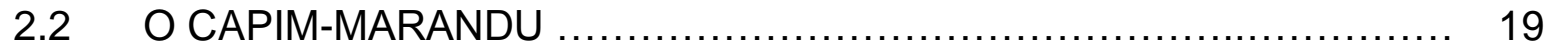

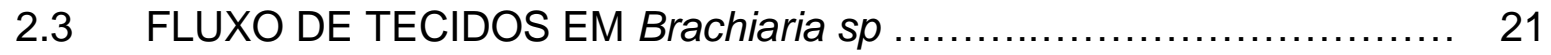

2.3.1 Taxa de aparecimento foliar $\left(\mathrm{TApF}^{-} \mathrm{n}^{\circ}\right.$ - folhas.perfilho $\left.{ }^{-1} \cdot \mathrm{dia}^{-1}\right) \ldots \ldots \ldots \ldots 23$

2.3.2 Taxa de alongamento foliar (TAIF - mm.perfilho ${ }^{-1} \cdot$ dia $^{-1}$ ) ................ 24

2.3.3 Duração de vida da folha (DVF - dias) e taxa de senescência foliar

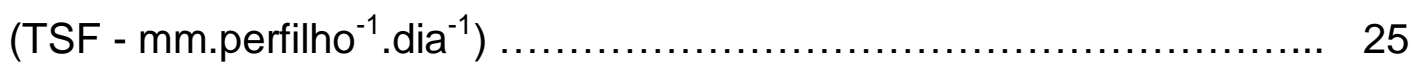

2.3.4 Taxa de alongamento de colmo (TAIC - mm.perfilho ${ }^{-1} \cdot$ dia $^{-1}$ ) ........... 26

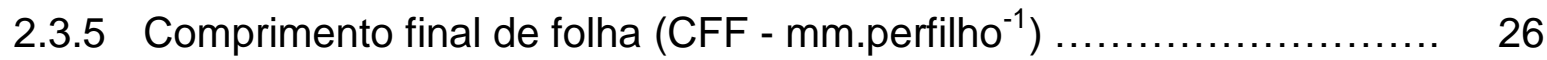

2.3.6 Número de folhas vivas (NFV - $\mathrm{n}^{-}$.perfilho ${ }^{-1}$ ) ........................ 27

2.3.7 Dinâmica de perfilhos ................................................................ 27

2.4 QUALIDADE NUTRITIVA DO PASTO ............................. 28

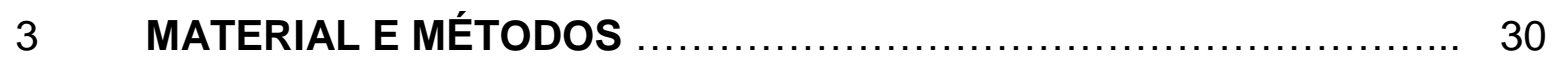

3.1 ADUBAÇÃO E CORREÇÃO DE SOLO .................................. 31

3.2 DELINEMANETO EXPERIMENTAL …….................................... 32

3.3 VARIÁVEIS ANALISADAS .............................................. 33

$3.4 \quad$ ANALISE ESTATÍSTICA ........................................... 36

$4 \quad$ RESULTADOS E DISCUSSÕES …................................ 37

$4.1 \quad$ MASSA SECA DE FORRAGEM ................................................ 37

4.2 CARACTERÍSTICAS MORFOGÊNICAS E ESTRUTURAIS ............. 39

4.2.1 Taxa de alongamento de folhas, taxa de aparecimentos de folhas e filocrono ................................................................ 39

4.2.2 Número de folhas vivas, duração de vida da folha e taxa de alongamento de colmos ................................................................. 43

4.2.3 Taxa de aparecimento de perfilhos ................................................ 48

4.2.4 Densidade populacional de perfilhos e taxa de senescência foliar ........ 49

4.2.5 Composição morfológica ................................................... 51

4.3 EFICIÊNCIA DO USO DO NITROGÊNIO ............................... 53 


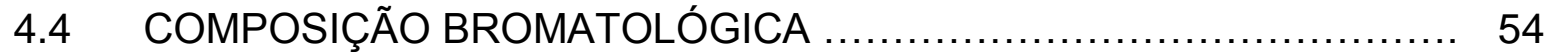

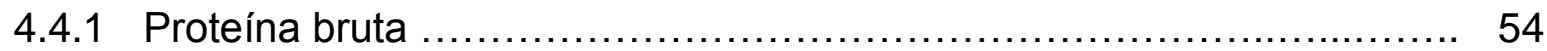

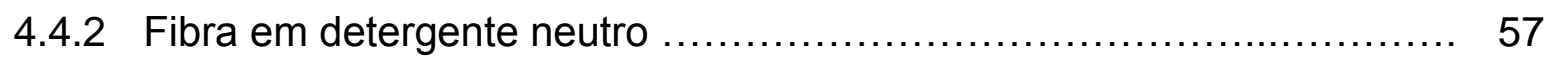

4.4.3 Fibra em detergente ácido..................................... 60

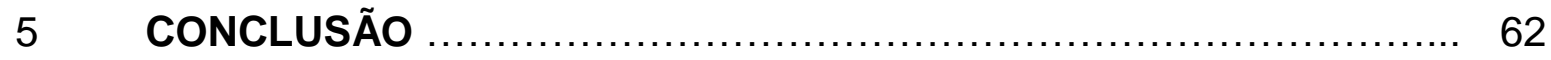

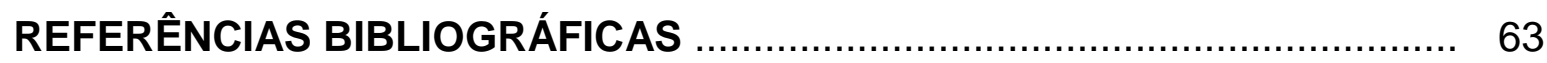




\section{INTRODUÇÃO}

No Brasil e em várias regiões do mundo, a pastagem é a principal fonte de volumoso para os herbívoros. Desde os primórdios da exploração pecuária, os solos reservados para implantação dos pastos eram os de baixa fertilidade natural, impróprios para a agricultura. Aqueles de melhor fertilidade somente eram explorados como pastos após sua utilização inicial com culturas anuais, estando, portanto, já desgastados e empobrecidos pelo uso intensivo e extrativo, sem o devido cuidado em conservá-lo.

As plantas forrageiras exploradas como cultura dependem de adequada nutrição mineral para externar seu potencial produtivo. Assim, torna-se imprescindível o estudo do fornecimento de nutrientes, em especial a combinação entre eles, associando as respostas morfofisiológicas das plantas forrageiras ao incremento na produção de massa seca (PMS).

Para superar os índices zootécnicos, novos estudos têm sido conduzidos para dar suporte à aplicação das técnicas, principalmente associados à fisiologia de plantas forrageiras, como dinâmica do crescimento e da senescência, nível de interceptação de luz e valor nutritivo da planta forrageira, que garantam a perenidade e a produtividade do pasto e consequentemente o ganho de peso animal.

A intensificação da produção de um pasto, utilizando-se do manejo racional independente do método de pastejo, pode garantir o meio propício para alta produção de massa e disponibilidade de nutrientes, e assim ser capaz de suprir as necessidades dos animais.

Neste contexto, a adubação passa e ser essencial se as condições climáticas forem favoráveis e o solo não oferecer impedimento físico que limitem o crescimento e desenvolvimento das plantas forrageiras, o uso de fertilizantes passa a ser de suma importância para equilibrar o fornecimento de nutrientes para que possa expressar seu potencial de produção de massa de forragem.

Em geral, as plantas forrageiras tropicais respondem positivamente à adubação nitrogenada. $\mathrm{O}$ suprimento de $\mathrm{N}$ interfere em todo o ciclo da forragem, inclusive na rebrotação após a desfolha, afetando por consequência as suas características morfofisiológicas (ALEXANDRINO, 2000). Esta é a ferramenta chave para aumentar a produção de forragem. 
No entanto, o excesso de $\mathrm{N}$ é prejudicial, devendo sua dose ser disponibilizada à planta forrageira para equilibrar a sua relação às demais fontes de nutrientes. $\mathrm{O}$ equilíbrio na utilização de fontes de $\mathrm{N}$ e a disponibilidade de luz na pastagem interferem no crescimento da planta forrageira.

Além da produção de massa seca, todo o cuidado deve ser dirigido ao valor nutritivo dessa massa. $O$ valor nutritivo da forragem é avaliado pela sua digestibilidade e composição bromatológica, principalmente, os teores de proteína bruta (PB) e de parede celular (GOMIDE et al., 2001). Burton (1998) concluiu que as adubações, principalmente a nitrogenada, além de aumentar a produção de MS, aumenta o teor de PB da forragem, mas, por outro lado, por efeito de diluição, diminui a porção de fibra em detergente neutro (FDN) e fibra em detergente ácido (FDA), o que contribui para melhorar a sua qualidade (CECATO; PEREIRA; JOBIM, 2004).

Segundo Lemaire e Chapman (1996), quando a planta forrageira é cortada ou pastejada, de forma intensa e severa, sua recuperação depende muito da disponibilidade de $\mathrm{N}$ no solo. Assim, para cada intensidade de pastejo, haveria a necessidade de se trabalhar melhor a fertilidade do solo.

Assim, conhecendo as necessidades da planta é possível adequar o melhor manejo do pasto, aumentar o ganho de peso animal e atingir o equilíbrio entre planta-animal. Hipotetiza-se que com o uso intensivo do pasto, associado às doses de $\mathrm{N}$ e melhor manejo, condicionariam à rápida rebrotação e melhor composição química do capim-marandu.

Deste modo, o presente trabalho teve por objetivo avaliar o comportamento do capim-marandu (Brachiaria brizantha cv. Marandu), utilizado por ovinos em lotação rotativa, mediante avaliação de suas características produtivas, morfogênicas e bromatológicas, quando adubado com doses de $\mathrm{N}$. 


\section{REVISÃO DA LITERATURA}

\subsection{A ADUBAÇÃO NITROGENADA E A PRODUÇÃO DE FORRAGEM}

O Nitrogênio é um macronutriente de grande importância para as diversas culturas vegetais, seja pelo uso de fertilizantes ou por ser constituinte químico das plantas (RAIJ, 1991). Ele tem função importante no desenvolvimento de perfilhos e, consequentemente, na PMS, porque faz parte das proteínas e ácidos nucléicos, que participam ativamente da síntese de compostos orgânicos, formadores da estrutura do vegetal (WHITEMAN, 1980; MALAVOLTA, 2006). Atua nos processos fotossintéticos, além de, segundo Werner (1986), dar porte à planta, influenciar no crescimento e tamanho das folhas e dos colmos, no aparecimento de perfilhos, garantir melhor vigor da rebrotação após o corte ou pastejo, o que resulta em maior produção e capacidade de suporte das pastagens (CECATO et al., 1996).

Sua fonte natural e principal no solo é a matéria orgânica, e sua disponibilidade às plantas é dependente do processo de mineralização pela ação de microrganismos, porém de forma lenta e contínua. Entretanto, em solos destinados ao pastejo, essa mineralização pode ocorrer de forma reduzida devido à compactação do solo, que resulta em déficit de oxigênio e redução na atividade microbiana (SOARES FILHO, 1993).

A absorção de $\mathrm{N}$ pelas plantas forrageiras varia de acordo com a espécie e as características edafoclimáticas. Em pastagens permanentes de sistemas naturais, o $\mathrm{N}$ disponível para absorção pode-se originar do processo de mineralização da matéria orgânica, dos resíduos vegetais, das excretas de animais em pastejo, da precipitação e da fixação biológica de $\mathrm{N}_{2}$. O N no solo, na forma de matéria orgânica e resíduo vegetal mineralizado, pode variar de 40 a $230 \mathrm{~kg} \mathrm{~N} \mathrm{ha}^{-1}$ ano-1, e está positivamente relacionado ao conteúdo da matéria orgânica do solo, e composição de resíduos em condições climáticas favoráveis (WOOD et al., 2012).

Sequndo Wood et al. (2012), comparativamente à mineralização dos resíduos vegetais, a deposição de excrementos de bovinos pode ser elevada, podendo atingir $1200 \mathrm{~kg} \cdot \mathrm{ha}^{-1} \mathrm{~N}$ depositados pela forma de fezes e urina animal durante épocas de pastejo intensivo, porém de forma concentrada em determinadas áreas. Esta deposição concentrada de $\mathrm{N}$ é considerada acima da capacidade de 
absorção pelas plantas forrageiras, o que, certamente, acarretará perdas por volatilização e lixiviação.

Embora autores como Vicent-Chandler et al. (1973); Lugão (2001); Queiroz Neto, Martha Jr. e Penati (2001); Aguiar, Bezerra Neto e Dantas (2002); Maya (2003) tenham observado resposta positiva para doses elevadas de N, o potencial de resposta das plantas forrageiras tropicais ao $\mathrm{N}$ tem sido linear para doses de 400 a $600 \mathrm{~kg} \mathrm{ha}^{-1}$. Devido a isto, esse macronutriente torna-se limitante na produção dessas plantas. Myers e Robbins (1991) reforçam a ideia da dependência de N pelas plantas forrageiras para produzirem e persistirem num determinado ambiente. A não observância de sua exigência tem levado a processo de degradação do solo e do pasto.

Fagundes et al. (2005), ao adubar Brachiaria decumbens com doses de N, encontraram efeito linear para produção de matéria seca. Dose de $300 \mathrm{~kg} \cdot \mathrm{ha}^{-1} \mathrm{de} \mathrm{N}$ proporcionou a PMS/ano de aproximadamente 10 t. MS. ha.ano ${ }^{-1}$, com aumento em relação à testemunha de 50\% de produtividade. Cabral et al. (2012), ao trabalhar em ensaios em Brachiaria brizantha cv. Xaraés encontraram PMS para a dose de 333 kg.ha ${ }^{-1} \mathrm{~N}$ de 6,2 t/ha/ano, sendo $87,5 \%$ superior ao encontrado para o controle $(3,32$ t.ha $^{-1}$ de MS). Também, trabalhando com Brachiaria brizantha cv. Xaraés, Rodrigues et al. (2008), em doses máximas de $176 \mathrm{mg} \cdot \mathrm{dm}^{3}$ de $\mathrm{N}$, obtiveram PMS de $40 \mathrm{~g} / \mathrm{vaso}$. Primavesi et al. (2006), trabalhando com doses crescente de $\mathrm{N}$ em Brachiaria brizantha cv. Marandu observaram PMS/ha/ano de 12,3 t, quando adubada com a dose de $800 \mathrm{~kg} \cdot \mathrm{ha}^{-1} \mathrm{~N}$ na forma ureia.

Após a desfolhação, o suprimento de $\mathrm{N}$ é importante para a recuperação da planta forrageira por alterar as características e adaptações morfofisiológicas apresentadas pelas plantas, quando cortada ou pastejada (ALVES et al., 2008). Segundo Vilela e Alvim (1998), o fornecimento de $\mathrm{N}$ altera a velocidade de crescimento das plantas forrageiras e isso proporciona maior frequência de cortes ou pastejos.

Para Blaser (1966), a adubação nitrogenada tem forte relação com as características estruturais das plantas forrageiras. Segundo Corsi e Silva (1994), a adubação nitrogenada aumenta a longevidade, a taxa de alongamento e o número de folhas, que resulta em acréscimo na densidade populacional de perfilhos (DPP). Não se deve esquecer que cada folha possui uma gema que poderá se desenvolver e originar novos perfilhos. O processo de formação e desenvolvimento de folhas é 
fundamental para o crescimento vegetal, dado o papel das folhas na fotossíntese, que representa o ponto de partida para a formação de novos tecidos (GOMIDE; GOMIDE, 2000).

O perfilhamento em gramíneas forrageiras é uma característica estrutural determinante da plasticidade morfogênica, influenciada por combinações de fatores nutricionais, ambientais e de manejo. (NABINGER, 1997).

A adubação nitrogenada propicia o desenvolvimento de novo tecido rico em proteína bruta (PB) e pobre em parede celular e lignina (WHITNEY, 1974).

Para Corsi et al. (2004), o uso de fertilizantes em pasto para a exploração animal, principalmente a nitrogenada, deverá ser cada vez mais adotada pelos produtores, visando a melhoria na eficiência econômica da atividade pecuária para atender a demanda de carne do mercado mundial.

\subsection{O CAPIM-MARANDU}

O capim-marandu pertence ao gênero Brachiaria, é classificado como Brachiaria brizantha (Hochst ex A. Rich) Stapf cv. Marandu. Origina-se de uma região vulcânica da África, onde os solos geralmente apresentam bons níveis nutrientes, com precipitação anual ao redor de $700 \mathrm{~mm}$ e cerca de 8 meses de seca no inverno (RAYMAN, 1983). Este cultivar é proveniente da Estação Experimental de Forrageiras de Marandellas, no Zimbabwe, na África. Foi introduzido no Brasil por volta de 1967, por iniciativa do produtor de sementes Paul Rankin Rayman e Dr. John Clatworthy, pesquisador da referida Estação Experimental (NUNES et al., 1984).

O capim-marandu, nome proveniente do guarani "novidade" é um ecotipo de Brachiaria brizantha que foi estudado pelo Centro Nacional de Pesquisa de Gado de Corte em Campo Grande - MS, em 1977 e pelo Centro de Pesquisa Agropecuária dos Cerrados em Planaltina - DF, em 1979. Mostrou-se, inicialmente, resistente às cigarrinhas das pastagens, bom valor forrageiro, alta produção de massa verde e de sementes viáveis, comparado à Brachiaria decumbens. Apresenta hábito de crescimento cespitoso, muito robusto, de 1,5 a 2,5 m de altura, com colmos iniciais prostrados, e afilhos predominantemente eretos (EMBRAPA, 1984). A qualidade como planta forrageira, segundo Nunes et al. (1984), significava excelente 
alternativa para o pecuarista, o que levou ao lançamento do cultivar pelos dois centros de pesquisa, recomendando-o para os cerrados de média à boa fertilidade.

As características de adaptação à temperatura (SKERMAN; RIVEIROS, 1992) e de produção de MS (GHISI; PEDREIRA, 1987) são importantes no sistema produtivo. Os primeiros autores relataram que a temperatura ideal para seu desenvolvimento encontra-se entre 30 a $35^{\circ} \mathrm{C}$, e a mínima em $15^{\circ} \mathrm{C}$, embora possa ter boa tolerância à geada. Em relação ao manejo de alturas adotado, quando em lotação contínua, deve ser pastejada de 20 a $40 \mathrm{~cm}$, se utilizado em lotação rotativa o manejo adequado é de $35 \mathrm{~cm}$ na entrada e $15 \mathrm{~cm}$ na saída dos animais para melhor aproveitamento do material verde em detrimento ao material senescente (HOGDSON; DA SILVA, 2002).

Quanto às exigências nutricionais, alguns experimentos foram conduzidos em condições controladas, como o de Monteiro (1994), utilizando o cultivar Marandu cultivado em solução nutritiva num experimento do tipo subtração de nutrientes. Constatou-se que a omissão de $\mathrm{N}$ e fósforo $(\mathrm{P})$ foi a mais restritiva à $P M S$ e à densidade populacional de perfilhos, sendo também a que primeiro manifestou sintomas de deficiência. Quanto ao perfilhamento, Morikawa (1993) também verificou efeitos limitantes, em ordem decrescente, do $\mathrm{P}, \mathrm{N}$ e enxofre (S). Carvalho et al. (1999) consideravam que adequado suprimento de $P$ no solo era essencial para o rápido e eficiente estabelecimento das pastagens, diante do importante papel que este nutriente desempenha no desenvolvimento do sistema radicular e no perfilhamento das gramíneas.

Quanto à produção de massa de forragem, o capim-marandu pode ter variação de 2 a 30 t. ha $a_{n o}^{-1}$. Paula et al. (2012) observaram produção anual de 20 t. com adubação nitrogenada. Nunes et al. (1984), encontraram produção de MS anual de 6, 2 toneladas. Gimenes et al. (2011), com o capim em condições mínimas de adubação obtiveram produtividade de $11 \mathrm{t}$. MS.ha.ano ${ }^{-1}$.

Quanto à sua composição bromatológica, o capim-marundu apresentou teores de PB na planta inteira de 5,8\% (NUNES et al. 1984), em condições mínimas de adubação. Costa et al. (2013) obteve valore de PB de 16\% quando adubadas com doses de nitrogênio de 400 kg.ha.ano ${ }^{-1}$ (COSTA et al., 2013). Para os teores de FDA e FDN, Maranhão et al. (2009) encontraram, respectivamente, 34 e 64\% sem o emprego da adubação nitrogenada, enquanto que para Costa et al. (2013) os teores de FDA e FDN, em condições adubadas, foram de $33 \%$ e $62 \%$, respectivamente. 


\subsection{FLUXO DE TECIDOS EM Brachiaria sp.}

As espécies e cultivares do gênero Brachiaria, atualmente, ocupam grandes áreas de pastagens cultivadas brasileiras, constituindo importantes opções para a alimentação dos herbívoros. Entre as diversas espécies deste gênero, Brachiaria decumbens Stapf e a Brachiaria brizantha (Hochst ex. A. Rich) Stapf apresentam ocupação de destaque nas áreas de pastagens cultivadas (ALMEIDA, 1998). Possuem metabolismo $\mathrm{C}_{4}$ e elevado potencial de produção de forragem (RODRIGUES; SANTOS, 2002).

O conhecimento da morfogênese das plantas forrageiras, que compõem as pastagens, é de extrema importância para tomada de decisão do manejo, desde a adubação até o controle da taxa de lotação (NABINGER; PONTES, 2001). Desta forma, abordagens sobre ecologia do pastejo, fluxo de tecidos e ecofisiologia de plantas forrageiras têm recebido mais atenção por parte de pesquisadores e técnicos. (NASCIMENTO JR., 2002).

A morfogênese pode ser definida como um processo dinâmico de geração e expansão da planta no espaço, sendo resultado de taxas de surgimentos de órgãos e do balanço entre crescimento, senescência e desfolha (CHAPMAN; LEMAIRE, 1993).

As plantas possuem padrão morfogênico programado geneticamente, porém pode ser modificado de acordo com as condições ambientais, como pluviosidade, temperatura, entre outras, alterando as características estruturais como taxas de expansão de meristemas, emissão de folhas e a dinâmica de órgãos em geral (GILLET; LEMAIRE; GOSSE, 1984).

As taxas de aparecimento e alongamento de folha e a duração de vida das folhas (DVF) constituem os fatores morfogênicos do perfilho que, sob a ação do ambiente, como luz, temperatura, água e nutrientes determinam as características estruturais do dossel, como o número de folhas por perfilho, tamanho das folhas e densidade de perfilhos, responsáveis pelo índice de área foliar (IAF) do pasto (GOMIDE, 1997). Por isto, suas respectivas taxas são importantes parâmetros no estabelecimento de modelos alternativos de manejo da pastagem, visando o aumento de produtividade e eficiência de utilização da forragem produzida (GRANT et al., 1988; PARSONS; PENNING, 1988). 
O conhecimento das taxas de aparecimento, alongamento e senescência foliares e de perfilhamento se reveste de fundamental importância para a interpretação do acúmulo de forragem em sistema de manejo específico e do efeito do clima na produção de forragem (GOMIDE, 1997).

No início do desenvolvimento de um perfilho, os recursos são utilizados de forma a alongar a área foliar para o crescimento da planta. A produção de tecidos foliares é um processo contínuo, regulado por variáveis ambientais e características do dossel (CHAPMAN; LEMAIRE, 1993).

Como a prioridade na alimentação animal é produzir folhas, o bom manejo do pasto passa necessariamente em conhecer e compreender não apenas o processo de transformação do pasto (forragem) em produto animal, mas, sobretudo entender e controlar os processos de crescimento e desenvolvimento que resultam na produção da forragem a ser consumida. Desta forma, quando se entende a dinâmica de crescimento e desenvolvimento das plantas que compõem um pasto e suas respostas morfofisiológicas aos fatores que as influenciam, torna-se mais fácil adequar o manejo deste visando à sustentabilidade do sistema de produção com alta produtividade dos componentes: planta e animal (NASCIMENTO JR., 2002).

Assim, a produção de forragem em pastagens, após o corte ou pastejo, é garantida pelos processos de aparecimento e crescimento de folhas e perfilhos. Por isto, as variáveis morfogênicas, taxas de aparecimento e alongamento de folhas e tempo de vida das folhas são importantes no estabelecimento de modelos de manejo da pastagem (PARSONS; PENNING, 1988).

A importância desses processos para o entendimento do fluxo de tecidos em plantas reside no fato de que a taxa de alongamento foliar (TAIF) em gramíneas é função do suprimento celular (número total de células produzidas) e da taxa e duração do processo de alongamento celular (MAcADAM; VOLENEC; NELSON, 1989; SCHNYDER et al., 2000). Schnyder et al., (2000) definiram a TAIF como sendo o produto de dois componentes principais: o tamanho da zona de desenvolvimento foliar e a taxa média de crescimento relativo dos tecidos na zona de desenvolvimento.

O crescimento foliar em gramíneas é predominantemente unidirecional (MAcADAM; VOLENEC;NELSON, 1989), resultado do fluxo de células entre as distintas zonas que compõem o crescimento foliar: zona de divisão, zona de alongamento e zona de maturação celular. Esta organização cria gradiente de 
desenvolvimento em que as células, dispostas em feixes paralelos, passam sucessivamente pelas fases de divisão, alongamento celular e deposição de tecidos estruturais da folha (GASTAL; NELSON, 1994; FRICKE; MCDONALD; MATTSONDJOS, 1997). Assim, busca-se avaliar a planta forrageira, utilizando variáveis morfogênicas capazes de fornecer informações para esclarecer e demonstrar métodos para sua melhor produção e manejo. Utilizam-se como variáveis as características morfogênicas e estruturais (CHAPMAN; LEMAIRE, 1993).

As características morfogênicas são:

- Taxa de aparecimento foliar (TApF);

- Taxa de alongamento foliar (TAIF);

- Taxa de senescência foliar (TSF);

- Duração de vida da folha (DVF); e

- Taxa de alongamento de colmo (TAIC).

A partir das características morfogênicas torna-se possível avaliar as características estruturais do pasto.

Características estruturais:

- Comprimento final de folha (CFF);

- Número de folhas vivas por perfilho (NFV); e

Densidade populacional de perfilhos (DPP).

Com a associação destas variáveis determina-se o relvado, e juntas, contribuem para a geração de estratégias refinadas de manejo e produção de forragem. Nesse sentido, torna-se importante o conhecimento da interdependência entre as características morfogênicas e estruturais da planta forrageira (SBRISSIA; da SILVA, 2001).

\subsubsection{Taxa de aparecimento foliar (TApF - $\mathrm{n}^{\circ}$ folhas. perfilho $\left.^{-1} \cdot \mathrm{dia}^{-1}\right)$}

A medida da TApF expressa o número médio de folhas surgidas por perfilho em um determinado período de tempo (NASCIMENTO JR., 2002). É um processo contínuo, uma vez que cada folha tem para seus tecidos, estádio de crescimento, maturação e senescência.

A TApF desempenha papel central na morfogênese, pois influencia diretamente todos os outros componentes da estrutura do pasto (SBRISSIA; DA 
SILVA, 2001). Após a desfolha da planta forrageira, a recuperação da produção é dependente da contínua emissão de folhas e perfilhos, e isso garante sua perenidade e produtividade (GOMIDE; GOMIDE, 1999).

O inverso da TApF é o intervalo de aparecimento de folhas ou filocrono (Fil), ou seja, estima-se o número de dias entre o aparecimento de duas folhas sucessivas (WILHELM; MAcMASTER, 1995). Além destes, o padrão de desfolha, também, influencia a TApF, principalmente quando relacionado às alterações na altura de corte ou pastejo e oferta de forragem (GRANT et al., 1988). Como o perfilhamento representa a capacidade de produção de massa da planta forrageira, a determinação da TApF pode refletir na capacidade da planta em perfilhar.

$O$ equilíbrio entre a TApF e a senescência de perfilhos é altamente dependente do regime de desfolhação do pasto, e determina a evolução do Índice de Área Foliar, considerado fator mais importante na determinação do aparecimento e senescência de perfilhos (LEMAIRE; CHAPMAN, 1996).

Alexandrino et al. (2004) e Silva et al. (2009) observaram para o capimmarandu maior TApF, quando houve aplicação de $\mathrm{N}$ comparada ao controle. $\mathrm{O}$ efeito de $\mathrm{N}$ na TApF tem relação direta com a espécie vegetal, com o nível de adubação nitrogenada e com o próprio manejo (ALEXANDRINO et al., 2005).

Os resultados relatados na literatura evidenciam a importância do $\mathrm{N}$ na redução do tempo para o aparecimento de duas folhas sucessivas, uma vez que aumenta a produção de novas células, que tem reflexo positivo no número de folhas por planta. Esse fato tem relevância, pois além de influenciar na produção de massa de forragem, as folhas representam o órgão das plantas forrageiras com melhor valor nutritivo (SILVA et al., 2009).

\subsubsection{Taxa de alongamento foliar (TAIF - mm.perfilho ${ }^{-1} \cdot \mathrm{dia}^{-1}$ )}

A medida da TAIF expressa o comprimento médio das folhas em expansão por perfilho em um determinado período de tempo. O alongamento foliar em gramíneas fica restrito à área da base da folha em expansão que está protegida pela bainha das folhas mais velhas e pelo pseudocolmo, e é ativa devido à demanda de nutrientes, principalmente N (SKINNER; NELSON, 1995). 
Lemaire e Chapman (1996) elencam a TAIF como a mais importante característica na morfogênese, pois é a partir dela que se dá a estrutura do pasto, Densidade Populacional de Perfilhos, entre outros.

A TAIF correlaciona-se positivamente com a massa de forragem e massa por perfilho (NELSON; ASAY; SLEPER, 1977; HORST; NELSON; ASAY, 1978), mas negativamente com o número de perfilhos por planta (JONES; NELSON; SLEPER, 1979). Há também relação com a taxa de desfolha e as folhas verdes remanescentes. A relação do tamanho do perfilho com a TAIF pode ser responsável pela longa duração das taxas de alongamento por perfilho para populações de perfilhos de diferentes tamanhos (GRANT; BERTHARM; LYNNETORVELL, 1981).

Gastal, Bélanger e Lemaire (1992) relataram, também, que o incremento da adubação nitrogenada para gramíneas forrageiras estimulou em três vezes o aumento na TAIF, se comparado com locais onde o nutriente foi baixo ou limitante. Alexandrino et al. (2004) e Santos et al. (2009) observaram o mesmo comportamento com Brachiaria brizantha cv. Marandu e Brachiaria decumbens.

2.3.3 Duração de vida da folha (DVF - dias) e taxa de senescência foliar (TSF mm.perfilho ${ }^{-1} \cdot$ dia $^{-1}$ )

A DVF e a TSF são influenciadas pela TAIF (NABINGER; PONTES, 2001). Assim, quando um perfilho atinge seu número máximo de folhas, deve haver equilíbrio entre o surgimento e a senescência das folhas e por consequência a duração de vida das mesmas (NABINGER; PONTES, 2001). Para Nabinger (1997), são essas variáveis que determinam o fluxo entre crescimento e senescência das plantas.

Para realizar o manejo da pastagem, é fundamental conhecer a DVF, uma vez que é indicativo do potencial de rendimento máximo da espécie (máxima quantidade de material vivo por área). Constitui variável importante para determinar a intensidade de pastejo na lotação contínua ou a frequência do pastejo na lotação rotativa, podendo permitir índices de área foliar próximos da maior eficiência de intercepção e máximas taxas de crescimento (NABINGER,1997).

Em pastagens de Brachiaria brizantha cv. Xaraes, Martuscello et al. (2005) verificaram que a DVF foi negativamente afetada pela adubação nitrogenada e que o 
decréscimo na DVF com as doses de $\mathrm{N}$ foi explicado pela maior renovação de tecidos em plantas adubadas com $\mathrm{N}$.

2.3.4 Taxa de alongamento de colmo (TAIC - mm.perfilho ${ }^{-1} \cdot$ dia $^{-1}$ )

A TAIC é uma característica morfogênica que auxilia na compreensão da estrutura do pasto, concomitantemente na relação lâmina/colmo.

O desenvolvimento do colmo também influencia a produção de forragem porque, dependendo do estádio de desenvolvimento do perfilho, o colmo tem prioridade na partição de fotoassimilados. Em decorrência da redução da luz pelo sombreamento, o colmo alonga para favorecer a fotossíntese do dossel (FAGUNDES et al., 2005).

Em plantas forrageiras tropicais, a fração colmo, importante para 0 crescimento, interfere na estrutura do dossel e nos processos de competição por luz (FAGUNDES et al., 2005). Pinto et al. (2001) observaram que, em plantas do gênero Cynodon sob lotação contínua, aproximadamente 60 a 75\% do crescimento era proveniente do alongamento de colmo, e não apenas da expansão de folhas.

Assim, alterar de forma positiva a taxa de lotação e o retorno dos animais ao pasto, no momento correto, evita perdas de matéria seca.

\subsubsection{Comprimento final de folha (CFF - mm.perfilho-1)}

O CFF é uma característica plástica, isto é pode ser modificada com a desfolha e estratégias de manejo pasto, e está diretamente relacionado com TApF e a TAIF (LEMAIRE; CHAPMAN, 1996).

A capacidade da planta em expandir suas folhas é dependente da taxa de alongamento do meristema intercalar (zonas de divisão celular). Essa zona de alongamento é um local ativo e tem grande demanda por nutrientes (SKINNER; NELSON, 1995).

Segundo Nabinger e Pontes (2001), em temperaturas similares, as folhas são maiores na fase reprodutiva do que na fase vegetativa, e que devido à relação com a TApF e a TAIF, o CFF é influenciado pela temperatura ambiente.

Alexandrino et al. (2005) observaram para o capim-marandu, que o CFF é uma característica importante, devido sua relação direta com o aparecimento e o 
alongamento foliar do perfilho. Por conseguinte, o menor tamanho de folha nas plantas que receberam baixo suprimento de $\mathrm{N}$ deveu-se à menor TAlF e por consequência menor CFF.

\subsubsection{Número de folhas vivas (NFV $-n^{\circ}-$ perfilho ${ }^{-1}$ )}

O NVF é uma característica genotípica bastante estável na ausência de deficiências hídricas ou nutricionais (NABINGER; PONTES, 2001).

Existe um sincronismo entre o aparecimento e a morte das folhas, onde geralmente o número de folhas verdes é constante, isto porque o fluxo é contínuo. Desta forma, o manejo das plantas forrageiras pode ser programado, e sempre que possível maximizado para aumentar a eficiência de uso do capim e diminuir as perdas de material vegetal (NABINGER; PONTES, 2001).

Ribeiro (2010) observou para o capim-tanzânia relação diretamente proporcional e linear entre doses de N e NFV para inclusão de 225 kg.N.ha ${ }^{-1}$.

Segundo Gomide, Gomide e Paciullo (2006), o uso de NFV, a equivalência entre a TAIF e senescência foliar por perfilho, bem como a redução do alongamento do colmo, constitui critério que se apresenta como orientador do manejo de gramíneas tropicais cespitosas.

\subsubsection{Dinâmica de perfilhamento}

O perfilho é a unidade básica de desenvolvimento das plantas forrageiras (NABINGER; MEDEIROS, 1995). Espécies de gramíneas perenes contêm dois grupos de perfilhos: os basilares, que se originam da base da planta e, mais tarde, possuem seu próprio sistema radicular, e os aéreos, que surgem a partir de gemas superiores dos colmos em florescimento ou com meristema decapitado, e que não desenvolveram sistema radicular independente (CHAPMAN; LEMAIRE, 1993).

O perfilhamento da planta forrageira é uma resposta à fertilidade do solo, associada à época, à frequência e ao intervalo entre cortes (CORSI; NASCIMENTO Jr., 1994).

Uma das formas de maximizar o perfilhamento e assim, aumentar a produção de massa, está em utilizar o $\mathrm{N}$, que estimula o perfilhamento da gramínea (FAGUNDES et al., 2006). 
A adubação nitrogenada interfere intensamente na ativação dos tecidos meristemáticos (ALEXANDRINO et al., 2004). Nabinger (1997) comentou que a deficiência de $\mathrm{N}$ aumenta o número de gemas dormentes, enquanto o suprimento permite o máximo perfilhamento.

Garcez Neto et al. (2002) destacaram o efeito do N no perfilhamento. Essa resposta varia, contudo, em função da espécie. Pinto et al. (1994) observaram incremento na densidade de perfilhos em resposta ao aumento da dose de 15 para $90 \mathrm{mg} \cdot \mathrm{dm}^{-3}$ de $\mathrm{N}$ apenas para o capim-setária em um estudo que possui ainda capim-guiné e capim-andropógon.

\subsection{QUALIDADE NUTRITIVA DO PASTO}

O valor nutritivo de uma forragem refere-se às características inerentes da forragem consumida, que determinam a concentração de energia digestível e sua eficiência de utilização. $O$ valor nutritivo é determinado pela concentração e digestibilidade de nutrientes e pela natureza dos produtos finais da digestão. Existem muitos fatores que afetam o desempenho animal, alguns são inerentes à forragem, como os químicos, físicos e estruturais; outros, à quantidade de forragem disponível por animal, ao potencial animal (idade, sexo, raça, estado fisiológico), às doenças, aos parasitas, ao clima (temperatura, precipitação pluvial, radiação solar) e à suplementação alimentar. Em resumo, qualidade de forragem é igual a desempenho animal, isto é, depende do consumo, da digestibilidade, do suprimento de nutrientes e da utilização (FONTANELI; FONTANELI, 2012).

Já a eficiência de utilização de plantas forrageiras pelos animais depende de

vários fatores, como o valor nutritivo e quantidade de forragem disponível na pastagem e o potencial genético do animal. Assim, quando a disponibilidade de forragem e o potencial do animal não são limitantes, a qualidade do pasto é expressa pela produção por animal, sendo diretamente relacionada ao consumo voluntário e à disponibilidade de nutrientes (REIS; RODRIGUES, 1993).

De acordo com VAN SOEST (1994), a parede celular é composta por carboidratos estruturais de baixa solubilidade (celulose, hemicelulose e lignina) além de sílica e cutina, os quais correspondem à fração fibra bruta (FB) da forragem, cuja digestão ocorre na sua totalidade pela ação enzimática dos microrganismos do trato gastrointestinal. Já o conteúdo celular é composto por amido e carboidratos solúveis, 
PB, lipídios, vitaminas e minerais, correspondendo à fração solúvel ou parcialmente solúvel e de alta digestibilidade da célula da planta, os quais são digeridos tanto por enzimas dos microrganismos como por aquelas secretadas pelo aparelho digestivo dos animais.

A parede celular pode ser separada em FDN que determina a sua concentração na planta e expressa a fibra digestível (celulose e hemicelulose) e FDA que determina a qualidade da parede celular (lignina, celulose, sílica e cutina). Estes dois componentes, FDN e FDA, determinam respectivamente o potencial de consumo e digestibilidade da matéria seca da planta e, por sua vez, o valor nutritivo da forragem quando associados com o teor de proteína, minerais, vitaminas e concentração energética (VAN SOEST, 1994).

A FDN de uma forragem é considerada importante não só para a avaliação de sua composição química, mas também pelo fato de a mesma estar relacionada com o consumo máximo de MS (MERTENS, 1994). Desta forma, plantas forrageiras com teores maiores de FDN teriam menor potencial de consumo.

Geralmente, a maior concentração da PB verificada em pastagens adubadas com N, deve-se ao aumento da participação da MS de folhas na massa seca total e da formação de tecidos jovens da planta. 


\section{MATERIAL E MÉTODOS}

O experimento foi conduzido na estação de verão de dezembro de 2011 a março de 2012 na Faculdade de Zootecnia e Engenharia de Alimentos - FZEA/USP, no Campus Pirassununga, localizada à latitude 21 59' S e 47 26' W, e altitude de $634 \mathrm{~m}$. O clima é classificado como subtropical do tipo Cwa de Köppen (KÖPPEN; GEIGER, 1928). Os dados meteorológicos (Figura 1) foram coletados na estação meteorológica localizada no Campus, próxima à área experimental, no setor das agrárias.

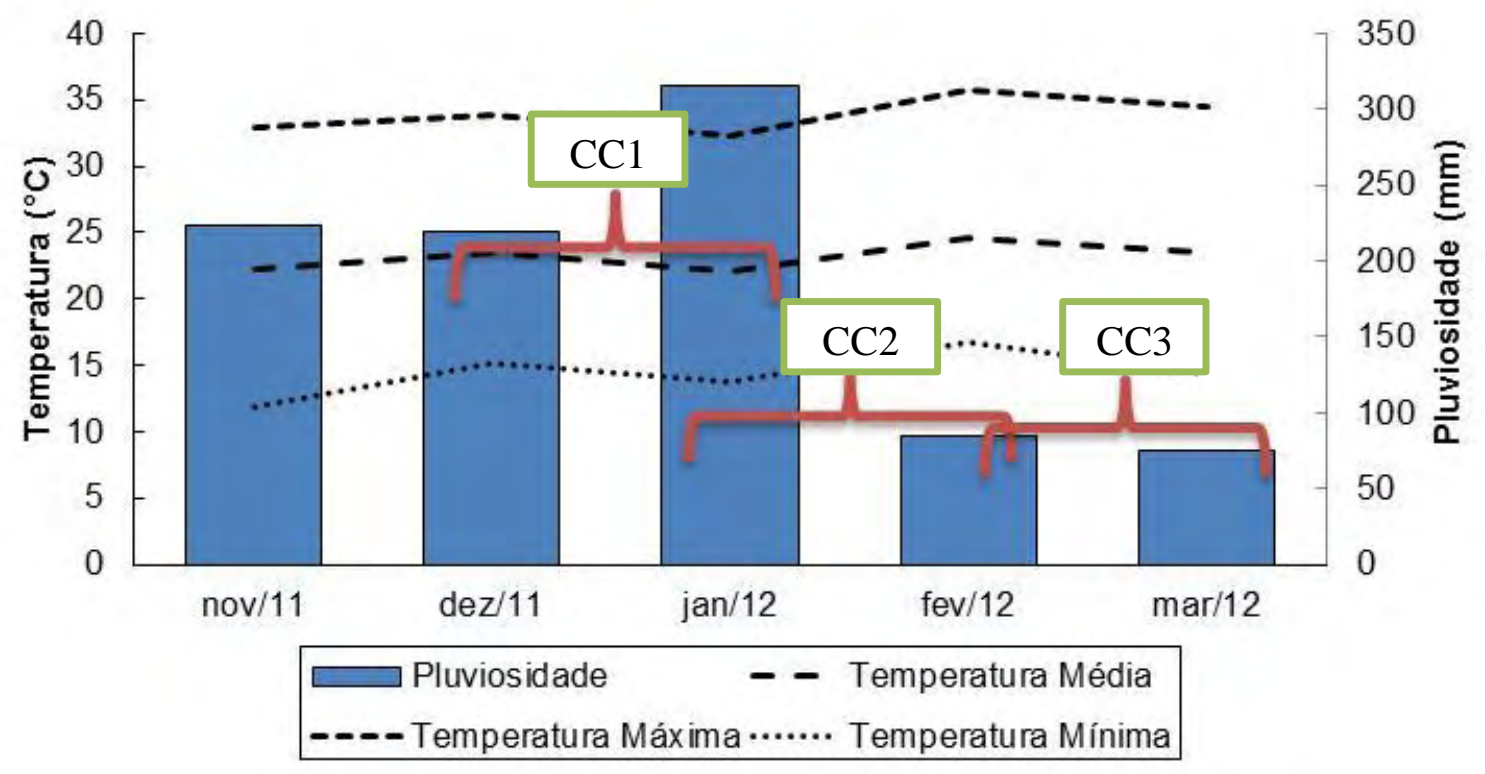

Figura 1. Temperatura máxima, mínima e média e pluviosidade total mensal durante o período experimental.

A área experimental consistiu de 04 unidades de pastejo (blocos) delimitada na figura a seguir na cor laranja (Figura 2), composta de 6 piquetes de $40 \times 20$ metros cada contornados na figura com as linhas pretas (Figura 2), nos quais cordeiros mestiços (Dorper $x$ Santa Inês) desmamados, de 2 a 3 meses, eram manejados em lotação rotativa, sendo 5 dias de ocupação e 25 dias de descanso, com ciclo de pastejo de 30 dias. A espécie forrageira estabelecida na área era Brachiaria brizantha cv. Marandu. 


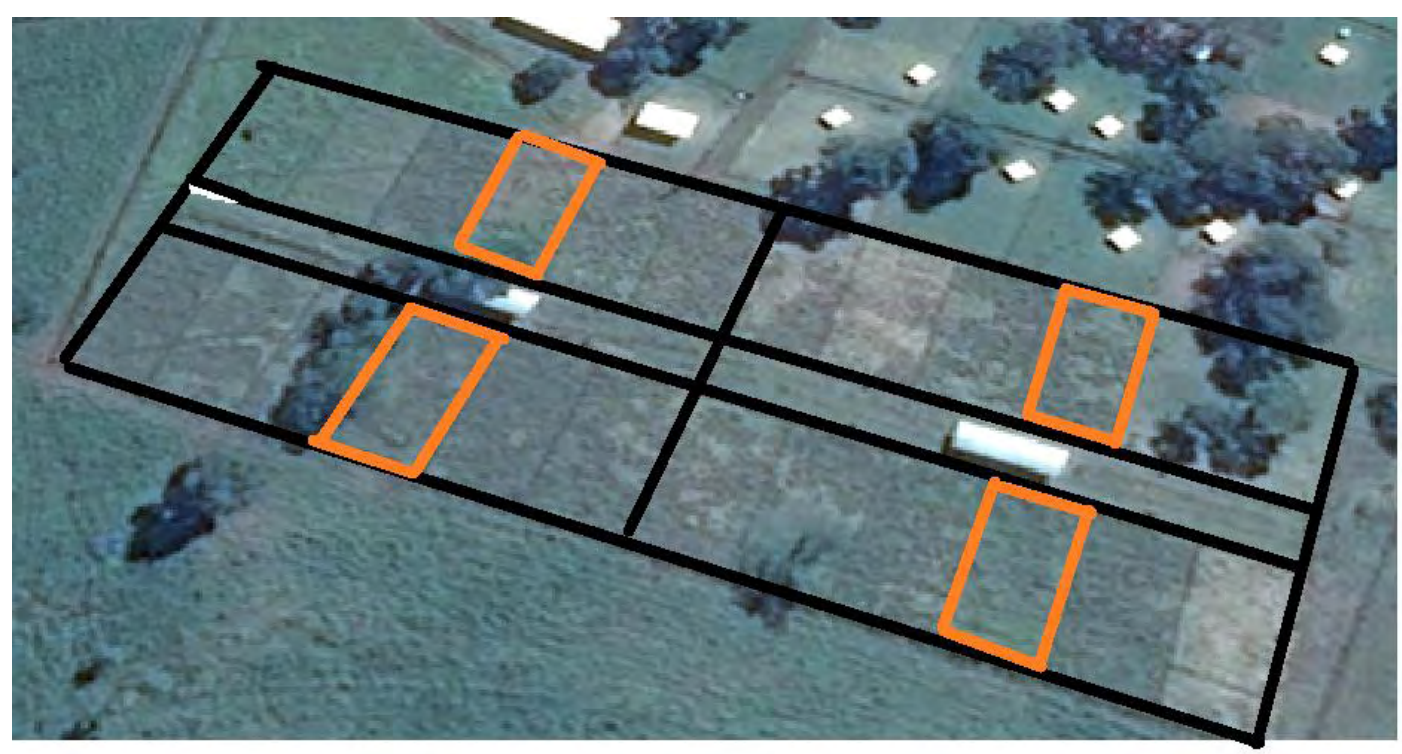

Figura 2. Vista aerea da área experimental.

\subsection{ADUBAÇÃO E CORREÇÃO DO SOLO}

Em junho de 2010, amostras do solo a $20 \mathrm{~cm}$ de profundidade foram retiradas para análise química, os resultados são apresentados, conforme tabela 1.

Tabela 1 . Análise química preliminar da amostra de solo da área experimental.

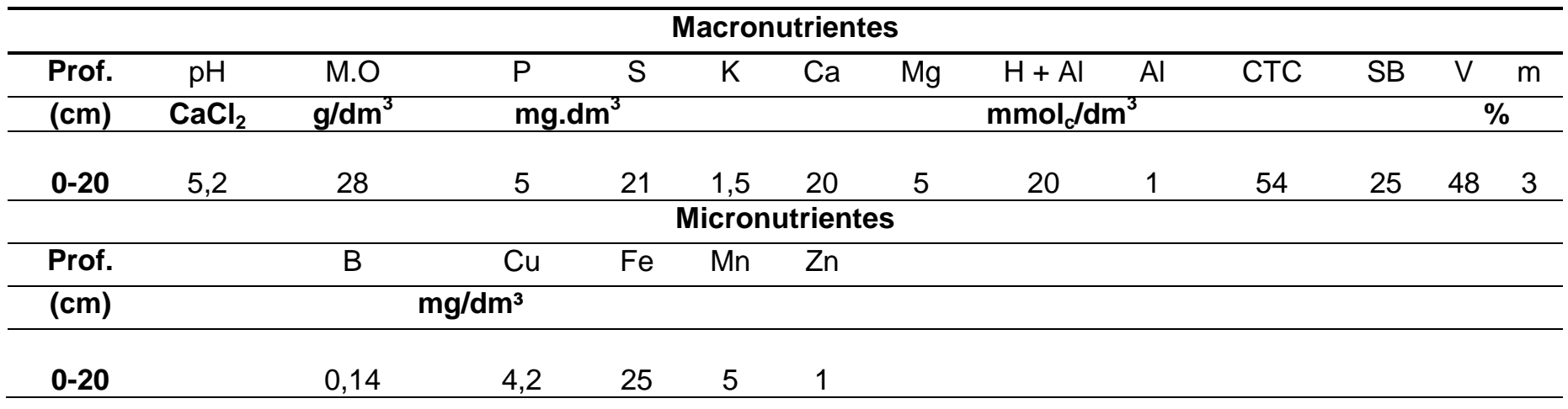

A correção do solo pela calagem foi realizada em julho de 2010 para elevação do índice de saturação de bases para $70 \%$ com a aplicação em área total de calcário dolomítico (90\% PRNT), na dosagem de 1,32 t/ha.

A adubação fosfatada em dose total foi realizada em março de 2011 para elevar os teores de fósforo no solo de $6 \mathrm{mg} / \mathrm{dm}^{3}$ para $20 \mathrm{mg} / \mathrm{dm}^{3}$. A fonte foi o superfosfato simples $\left(18 \% \mathrm{P}_{2} \mathrm{O}_{5}\right)$ na dose de $777 \mathrm{~kg} / \mathrm{ha}\left(140 \mathrm{~kg}\right.$ de $\left.\mathrm{P}_{2} \mathrm{O}_{5} / \mathrm{ha}\right)$. Optou- 
se também pela aplicação de $50 \mathrm{~kg} / \mathrm{ha}$ de nitrogênio $(\mathrm{N})$ e potássio $\left(\mathrm{K}_{2} \mathrm{O}\right)$, utilizandose da fórmula 20 - 00 - 20 (250 kg/ha). De março a outubro de 2011, a área experimental não teve a presença de animais, permanecendo em descanso.

Em setembro de 2011, foi realizado outra coleta de solo para verificar as condições químicas anteriores à implantação do experimento. Foram coletados solos na profundidade de $0-20 \mathrm{~cm}$ e $20-40 \mathrm{~cm}$, sendo os resultados apresentados na tabela 2.

Nessa mesma época os pastos foram roçados a $15 \mathrm{~cm}$ de altura. Da roçada ao início do período experimental, no final de outubro de 2011, os animais começaram o pastejo para uniformizar os piquetes à altura média de $15 \mathrm{~cm}$. . Após esse $1^{\circ}$ ciclo de pastejo de uniformização, fez-se a escolha do $3^{\circ}$ piquete em cada bloco para alocar as parcelas experimentais, considerado a mais homogêneo, e também livre de sombra.

Tabela 2 . Análise química de amostra de solo da área experimental

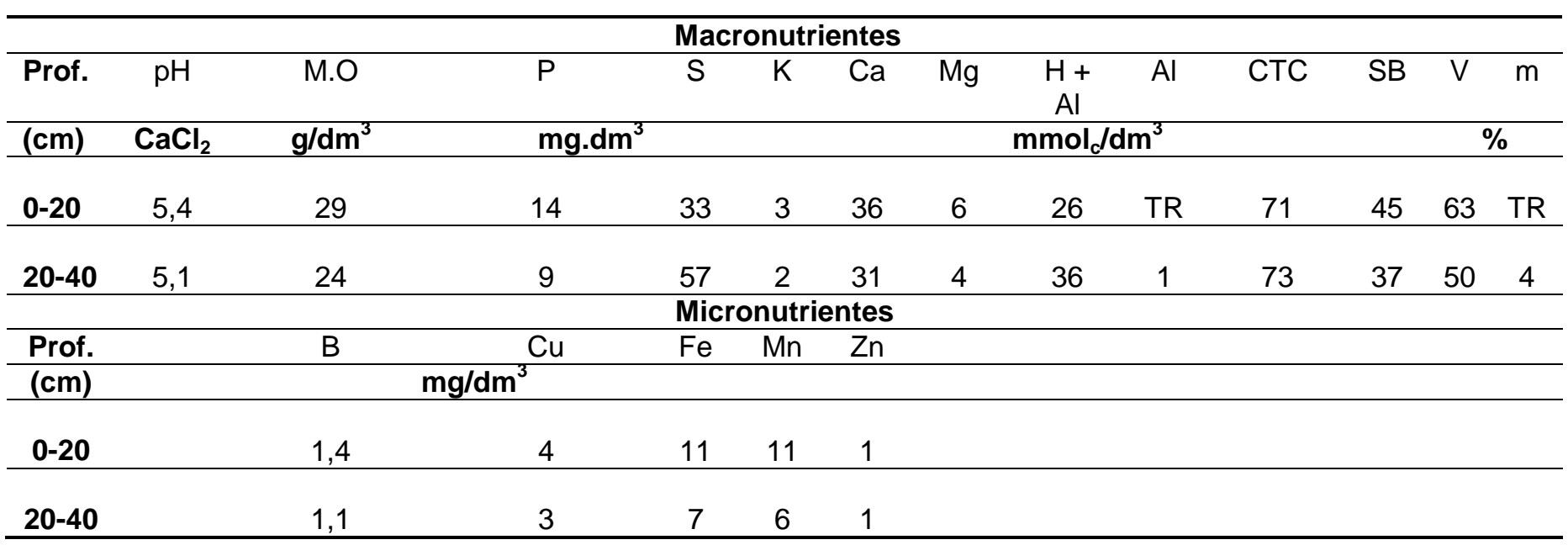

\subsection{DELINEAMENTO EXPERIMENTAL}

Dentro desses piquetes, em todos os blocos, foram alocadas 5 parcelas de 9 $\mathrm{m}^{2}$. O tratamento experimental consistia de 5 doses de nitrogênio: 0, 90, 180, 270 e $360 \mathrm{~kg}$ de N.ha ${ }^{-1}$. Aplicadas na forma de ureia. O delineamento experimental foi em blocos completos casualizados com quatro repetições (bloco), totalizando vinte parcelas experimentais. 
As avaliações das parcelas experimentais foram realizadas em três ciclos de crescimento, de dezembro de 2011 a março de 2012. O 1ำ ciclo de crescimento ocorreu de 11 de dezembro a 10 de janeiro; o $2^{\circ}$ ciclo foi de 10 de janeiro a 9 de fevereiro, e o $3^{\circ}$ ciclo de 9 de fevereiro a 11 de março.

As adubações nitrogenadas foram parceladas em três aplicações, sendo realizadas na saída dos animais do piquete , caracterizando, assim, final de um ciclo e início do período de avaliação.

As condições de alturas de entrada e saída dos animais nos piquetes foram abaixo do que se preconiza em literatura, sendo a entrada dos animais nos piquetes com a altura de $15 \mathrm{~cm}$ e a saída deixando um resíduo de aproximadamente $6 \mathrm{~cm}$.

\subsection{VARIÁVEIS ANALISADAS}

As características morfogênicas foram avaliadas após a saída dos animais dos piquetes e durante todo período de descanso. Em cada parcela experimental foram marcados, com anel plástico colorido, cinco perfilhos para avaliar o fluxo de tecidos (Figura 3), durante três ciclos de pastejo, e a cada ciclo novos perfilhos eram marcados para avaliação.

As medições foram realizadas a cada três dias, utilizando-se de uma régua graduada em milímetros. O comprimento das folhas expandidas foi medido desde a ponta da folha até sua lígula. No caso de folhas emergentes e em expansão, o mesmo procedimento foi adotado, porém era considerada a lígula da última folha expandida como referencial de mensuração. Para folhas em senescência, o comprimento correspondente ao tecido senescido era medido. $\mathrm{O}$ tamanho do colmo foi mensurado como a distância desde a superfície do solo até a lígula da folha mais jovem completamente expandida. 


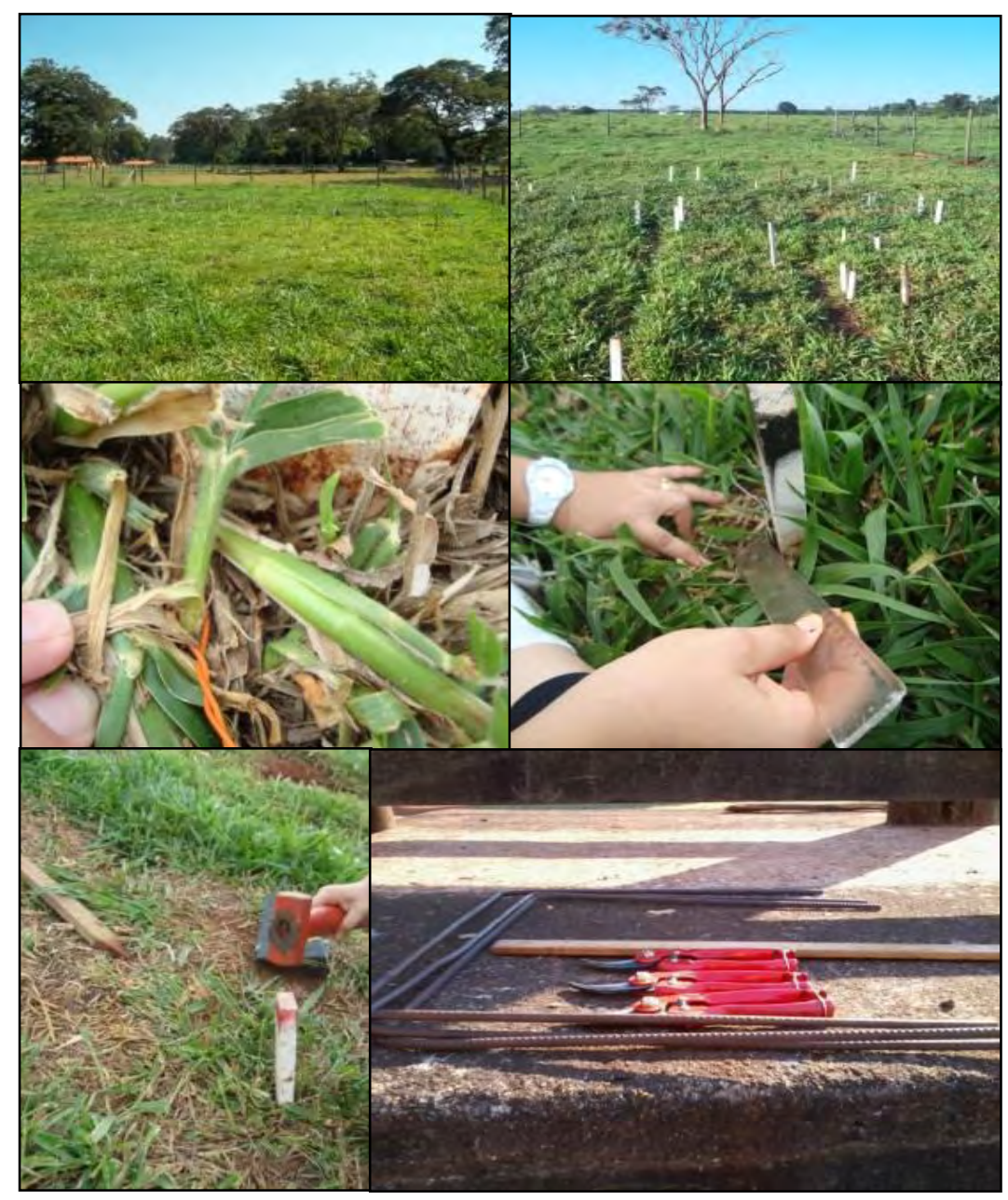

Figura 3. Fotos do piquete, das parcelas experimentais, ferramentas, marcação de perfilho e medição de folhas.

A partir dessas medidas foram calculadas as variáveis:

- Taxa de aparecimento de folhas (TApF - folhas.perfilho ${ }^{-1}$.dia ${ }^{-1}$ ): número de folhas surgidas por perfilho, dividido pelo número de dias do período de avaliação;

- Filocrono (Fil-dias.folha ${ }^{-1}$ ): número de dias para o aparecimento de duas folhas sucessivas. Também pode ser obtido pelo inverso da taxa de aparecimento foliar (1/TApF);

- Taxa de alongamento de folhas (TAIF - mm.perfilho ${ }^{-1} \cdot \mathrm{dia}^{-1}$ ): somatório de todo alongamento da lâmina foliar por perfilho dividido pelo número de dias do período de avaliação;

- Taxa de alongamento de colmo (TAIC - mm.perfilho ${ }^{-1} \cdot$ dia $^{-1}$ ): somatório de todo alongamento de colmo e, ou, pseudocolmo, por perfilho dividido pelo número de dias do período de avaliação; 
- Número de folha viva por perfilho (NFV - no): número médio de folhas por perfilho completamente expandidas;

- Duração de vida da folha (DVF - dias): estimada pela equação DVF = NFV x Filocrono (LEMAIRE; CHAPMAN, 1996);

- Taxa de senescência de folhas (TSF - mm.perfilho ${ }^{-1}$. dia $^{-1}$ ): variação média e negativa no comprimento da lâmina foliar, resultado da diminuição da porção verde da lâmina foliar, dividido pelo número de dias do período de avaliação;

- Comprimento final da lâmina foliar (CFF - mm): comprimento médio de todas as folhas presentes no perfilho multiplicado pelo número de folhas vivas.

Para estimativa da DPP e da taxa de aparecimento de perfilhos (TApP) foi usado uma área retangular de $50 \times 25 \mathrm{~cm}$ de lado, ajustado em um ponto fixo por parcela experimental na saída dos animais dos piquetes. Os perfilhos existentes no interior da área foram contados no início e final do período de descanso, e cortados ao nível do solo no final do período de descanso e armazenados em sacos de papel. Em seguida, as amostras foram levadas ao laboratório, secadas em estufa de circulação forçada de ar para a determinação do peso médio dos perfilhos (PMP) por área para cada tratamento.

A variável eficiência do uso do nitrogênio (EUN) pela planta forrageira foi determinada subtraindo-se da produção total de $\mathrm{MS}\left(\mathrm{kg}\right.$ de $\left.\mathrm{MS} \cdot \mathrm{ha}^{-1}\right)$, para cada tratamento com $\mathrm{N}$, a produção obtida do tratamento sem adubação nitrogenada. A diferença de produção foi dividida pela dose total de $\mathrm{N}$ empregada no respectivo período e tratamento. A relação $\mathrm{kg}$ de $\mathrm{MS} . \mathrm{kg}$ de $\mathrm{N}^{-1}$ representou quantos $\mathrm{kg}$ de $\mathrm{MS}$ foram produzidos para cada $1 \mathrm{~kg}$ de $\mathrm{N}$ aplicado na pastagem, demonstrando a eficiência de utilização do nutriente (CASTAGNARA et al., 2011).

Para a determinação da produção total de MS por hectare foram utilizados dois quadrados de $50 \times 50 \mathrm{~cm}$ de lado. Em cada parcela experimental, cortou-se ao nível de solo toda planta forrageira contida dentro dele, com o auxílio de uma tesoura de poda. Estas amostras, também, foram encaminhadas ao laboratório e secas em estufa de secagem forçada a $60^{\circ} \mathrm{C}$ por aproximadamente 72 horas ou até atingir um peso constante. A massa de forragem natural colhida nos dois quadrados foi multiplicada pelo teor de MS para a obtenção da massa seca de forragem. 
Este material, posteriormente a secagem, foi dividido em partes para a realização da separação morfológica, onde se obteve: material da planta inteira (PI), da lâmina foliar (LF), do colmo e bainha (CB), e do material morto (MM). A proporção de cada componente morfológico foi expressa como percentagem do peso total.

As amostras, após estufa, foram moídas em moinho do tipo Willey dotado com peneira de malha de 1 milimetro e acondicionadas em sacos plásticos, previamente identificados, para posteriores análises dos teores de MS e PB de acordo com AOAC (1980), e FDN e FDA (VAN SOEST, 1994).

\subsection{ANÁLISE ESTATIISTICA}

O experimento envolveu medidas repetidas no tempo, 3 ciclos de crescimento. $O$ fator tratamento foi dose de nitrogênio com 5 níveis. $O$ efeito do aumento das doses de nitrogênio nos três ciclos nas diversas variáveis respostas foi avaliado em uma análise de variância, baseada em um modelo linear misto. Um posterior estudo de regressão foi feito visando o ajuste de curvas polinomiais para explicar o comportamento das respostas médias em função do aumento das doses de $\mathrm{N}$ e dos ciclos.

Utilizou-se o PROC MIXED do SAS (2003) e a escolha da melhor estrutura de covariâncias entre as medidas repetidas no tempo foi baseada no menor valor dos critérios de informação de Akaike (AIC) e bayesiano de Schwarz (BIC). 


\section{RESULTADOS E DISCUSSÕES}

\subsection{MASSA SECA DE FORRAGEM (MSF)}

Para MSF (Figura 4) houve efeitos significativos de doses de $\mathrm{N}$ e ciclos de crescimento $(P<0,05)$, porém sem interação entre estes $(P>0,05)$.

$E m$ relação às doses de $\mathrm{N}$ aplicadas e o aumento da MSF, houve efeito quadrático, ou seja, a produção máxima de MSF ocorreu, quando se adubou com o equivalente a $246 \mathrm{~kg} \cdot \mathrm{ha}^{-1}$ de $\mathrm{N}$, após esta dose, o incremento de $\mathrm{N}$ não elevou a produção de MSF, provavelmente devido à limitação da planta de metabolizar o $\mathrm{N}$ na forma de amônio ou nitrato na ausência de alguns íons como sulfato (CRAWFORD et al., 2000; OLIVEIRA et al., 2005).

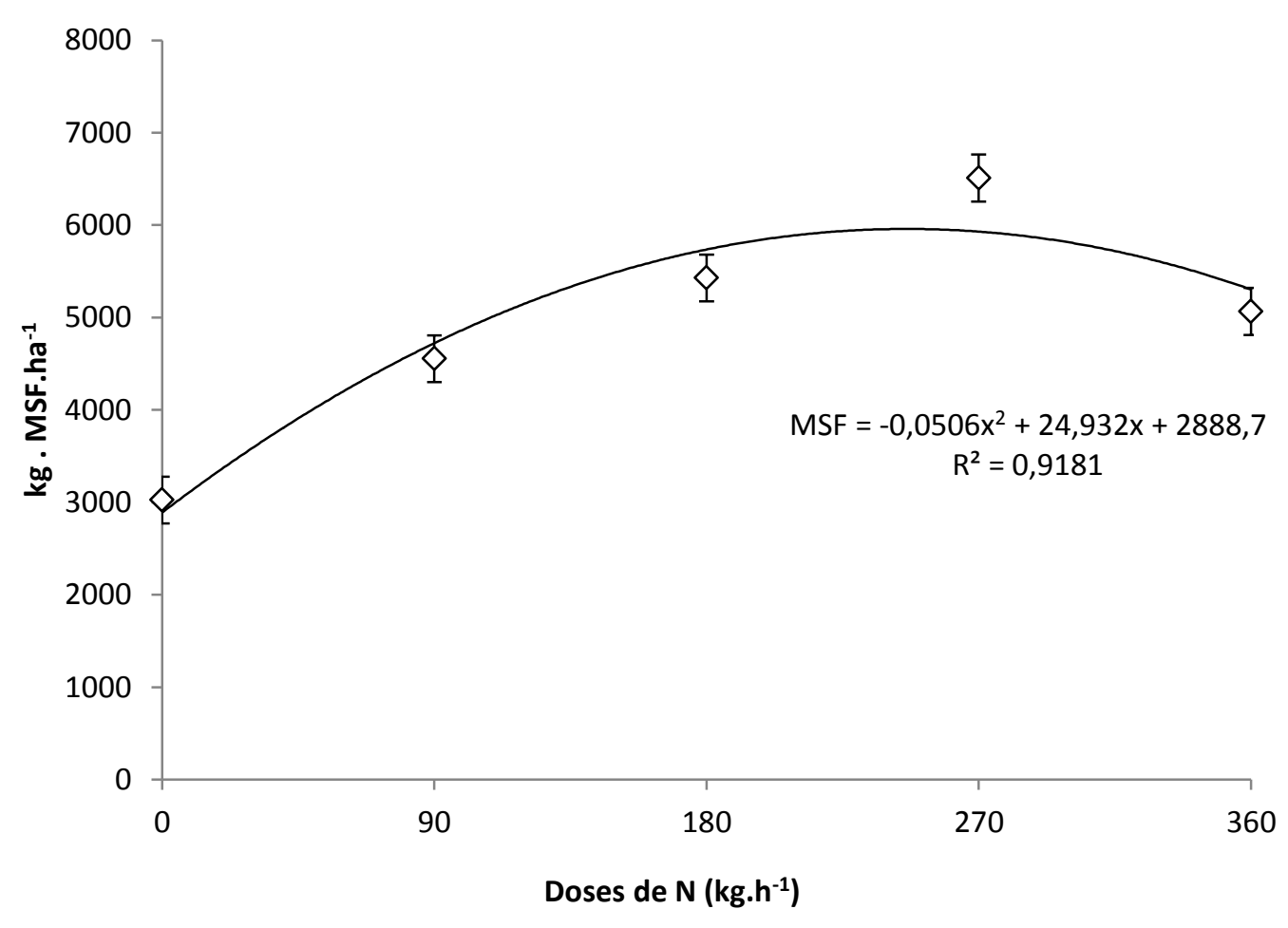

Figura 4. Massa seca de forragem de Brachiaria brizantha cv. Marandu, adubada com doses de $\mathrm{N}$, considerando as médias dos ciclos de crescimento.

Em relação aos ciclos de crescimento, as médias para os $\mathrm{CC}_{1}$ (dezembro 2011/janeiro 2012), $\mathrm{CC}_{2}$ (janeiro/fevereiro 2012) e $\mathrm{CC}_{3}$ (fevereiro/março 2012) foram respectivamente, 4126, 5263 e $5359 \mathrm{~kg} \cdot \mathrm{ha}^{-1}$ de MS (Tabela 3). 
Tabela 3. Médias da massa seca de forragem (kg MSF.ha ${ }^{-1}$ ) da Brachiaria brizantha cv. Marandu adubada com doses de N, nos ciclos de crescimento.

\begin{tabular}{|c|c|c|c|}
\hline \multicolumn{4}{|c|}{ Ciclo de Crescimento } \\
\hline & $1^{\circ}$ & $2^{\circ}$ & $3^{\circ}$ \\
\hline & Dez/11 a Jan/12 & Jan a Fev/12 & Fev a Mar/12 \\
\hline \multicolumn{4}{|c|}{ Massa seca de Forragem (kg MSF.ha ${ }^{-1}$ ) } \\
\hline Médias & $4125,62 \mathrm{~b}$ & $5263,45 a$ & $5359,45 a$ \\
\hline EPM & 278,82 & 278,82 & 278,82 \\
\hline
\end{tabular}

Essa variação esteve relacionada às condições climáticas durante os ciclos de crescimento (Figura 1), quando a temperatura mínima média esteve acima de $15^{\circ} \mathrm{C}$ e a menor precipitação foi de $80 \mathrm{~mm}$ no decorrer do $3^{\circ}$ ciclo de crescimento.

Estes resultados corroboram com os encontrados por Malavolta (2006), em que $\mathrm{o} N$ exerce papel importante no desenvolvimento de perfilhos e, consequentemente, na produção de MS, pois ele faz parte das proteínas e ácidos nucléicos, os quais participam ativamente na síntese de compostos orgânicos, que formam a estrutura do vegetal.

Silva et al. (2013), em estudos de recuperação de pasto formado por capimmarundú, constataram aumento na MS das lâminas foliares, em relação ao controle, de 212 e $151 \%$, para a dose de $300 \mathrm{~kg} \cdot \mathrm{ha}^{-1} \mathrm{ano}^{1} \mathrm{~N}$, considerando as fontes sulfato de amônio e uréia, respectivamente.

$\mathrm{O} \mathrm{N}$ é fator controlador dos diferentes processos de crescimento $\mathrm{e}$ desenvolvimento das plantas e proporciona aumento de biomassa devido ao incremento na fixação de carbono, assim maior área para captação de energia pode promover maior acúmulo de biomassa (NABINGER, 2001).

Fagundes et al. (2005), em estudo realizado com Brachiaria decumbens adubada com doses de $\mathrm{N}$, obtiveram resposta linear com o acréscimo de até 300 kg. ha ${ }^{-1} a^{-1}$ de $\mathrm{N}$ na PMS, sendo a máxima MSF, do presente estudo, atingida com a dose de $270 \mathrm{~kg} \cdot$ ha $^{-1}$.ano ${ }^{-1}$ de N. O comportamento quadrático ocorrido devido ao aumento da dose de $\mathrm{N}$ da ordem de $360 \mathrm{~kg} \mathrm{~N}$ ha.ano-1, mostrando comportamento similar ao encontrado pelos autores acima.

Cabral et al. (2012), em estudos com Brachiaria brizantha cv. Xaraés, encontraramcomportamento similiar ao do presente estudo. Assim, na avaliação da disponibilidade de massa seca total, no período das águas, em função da adubação 
nitrogenada, verificaram efeito quadrático, com a máxima produção obtida na dose de $385 \mathrm{~kg} \mathrm{ha}^{-1}$ de N, sendo $89 \%$ superior ao controle.

Bonfim da Silva e Monteiro (2006), trabalhando com recuperação de pastagens degradadas do capim-braquiaria, e avaliando efeitos de doses de $\mathrm{N}$ e $\mathrm{S}$ verificaram que $\mathrm{o}$ aumento das doses de $\mathrm{N}$ contribuiu efetivamente para $\mathrm{o}$ acréscimo na massa seca de lâminas foliares e na recuperação da planta forrageira.

\subsection{CARACTERÍSTICAS MORFOGÊNICAS E ESTRUTURAIS}

4.2.1 Taxa de alongamento foliar, taxa de aparecimento foliar e filocrono

Pelos resultados obtidos para TAIF, TApF e Fil (Figura 5, 6 e 7), constataramse efeitos significativos para as doses de $\mathrm{N}$ e ciclos de crescimento (Tabela 4) $(P<0.001)$, porém não houve interação entre estes $(P>0,05)$.

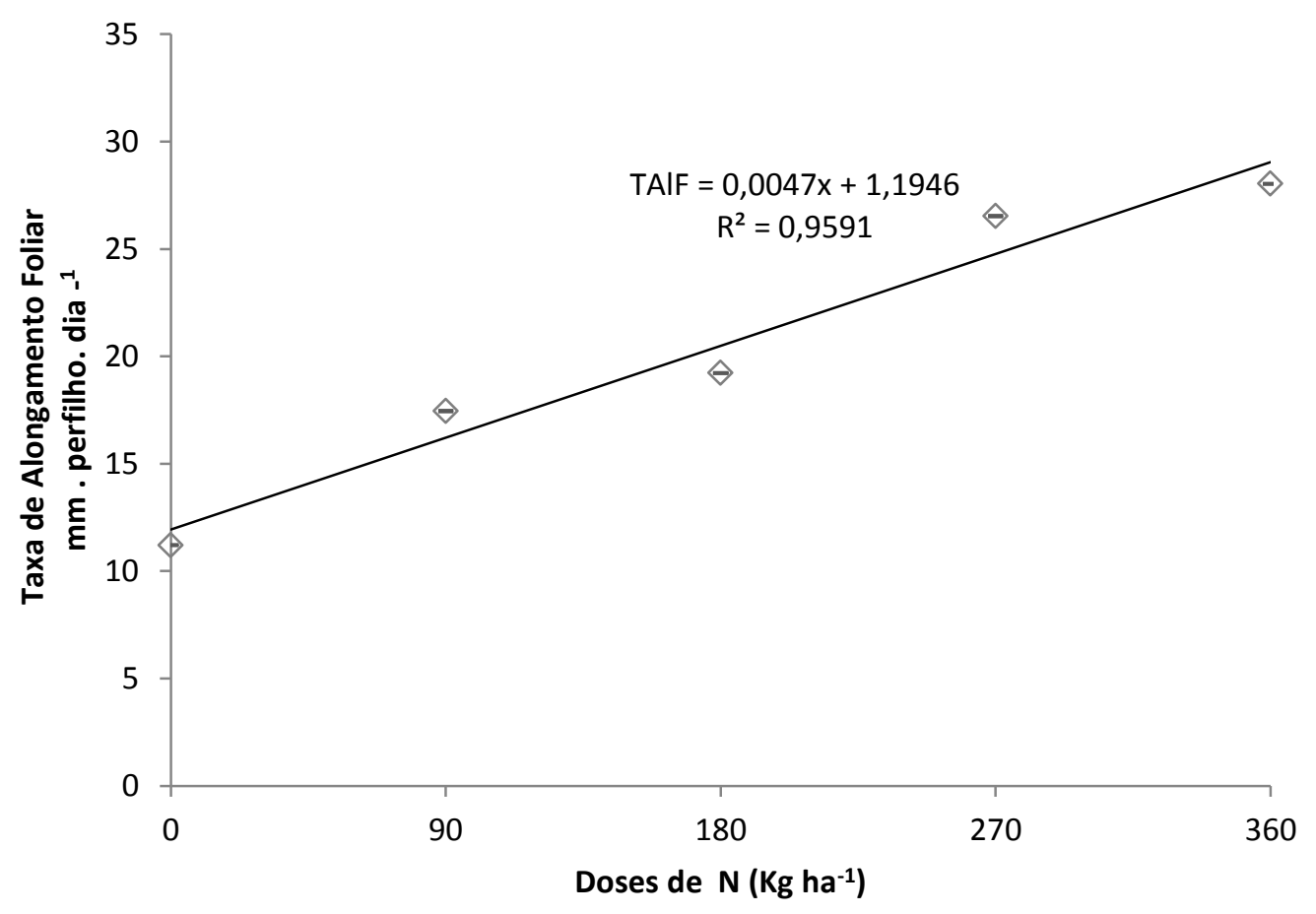

Figura 5. Taxa de alongamento foliar (mm.perfilho ${ }^{-1} \cdot \mathrm{dia}^{-1}$ ) de Brachiaria brizantha cv. Marandu adubada com doses de $\mathrm{N}$, considerando as médias dos ciclos de crescimento. 
Houve efeito linear $(P<0,05)$ de doses de $N$ na TAIF. $O$ efeito da adubação nitrogenada naTAIF é atribuído à grande influência de $\mathrm{N}$ nos processos fisiológicos da planta. Entre os benefícios da aplicação de $\mathrm{N}$, destacam-se o estímulo ao desenvolvimento dos primórdios foliares, o aumento do NFV, a diminuição do intervalo de tempo para aparecimento de folhas, a redução da senescência foliar e o estímulo ao perfilhamento (PACIULLO; GOMIDE; RIBEIRO, 1998).

A capacidade da planta em expandir suas folhas é dependente da taxa de alongamento do meristema intercalar. Trata-se da zona de divisão celular, local ativo de grande demanda por nutrientes (SKINNER; NELSON, 1995).

Fagundes et al. (2006), ao trabalharem com Brachiaria decumbens sob pastejo e adubada com $300 \mathrm{~kg} \mathrm{ha}^{-1}$ de $\mathrm{N}$, encontraram crescimento de 1,6 mm.perfilho.dia ${ }^{-1}$ para a TAIF, considerado inferior ao encontrado no presente estudo.

A TAIF é uma medida de grande importância na análise de fluxo de tecidos das plantas e correlaciona-se positivamente com o rendimento forrageiro (HORST; NELSON; ASAY, 1978). Casagrande et al.(2010), estudando Brachiaria brizantha cv. Marandu em condições de ofertas de forragem, não identificaram diferenças entre seus tratamentos, porém obtiveram TAIF de $17,5 \mathrm{~mm}$ dia $^{-1}$ perfilho ${ }^{-1}$. Alexandrino et al. (2005) observaram para Brachiaria brizantha cv. Marandu, crescendo em vasos, TAIF da ordem de $26 \mathrm{~mm}$ dia $^{-1}$. perfilho ${ }^{-1}$, quando adicionaram $360 \mathrm{Kg}$ de N ha ${ }^{-1}$.

Orrico Jr. et al. (2013), num estudo referente a utilização de efluente de avicultura em Brachiaria brizantha cv. Piatã, observaram incremento de $201 \%$ na TAIF, quando comparadas as doses de 50 e $250 \mathrm{~kg} \cdot \mathrm{ha}^{-1}$ de N. Resultado esse que corrobora com os encontrados neste estudo que foi $28 \mathrm{~mm} \cdot$ dia $^{-1}$.perfilho ${ }^{-1}$ com a dose de $360 \mathrm{~kg}$ de $\mathrm{N}$. 


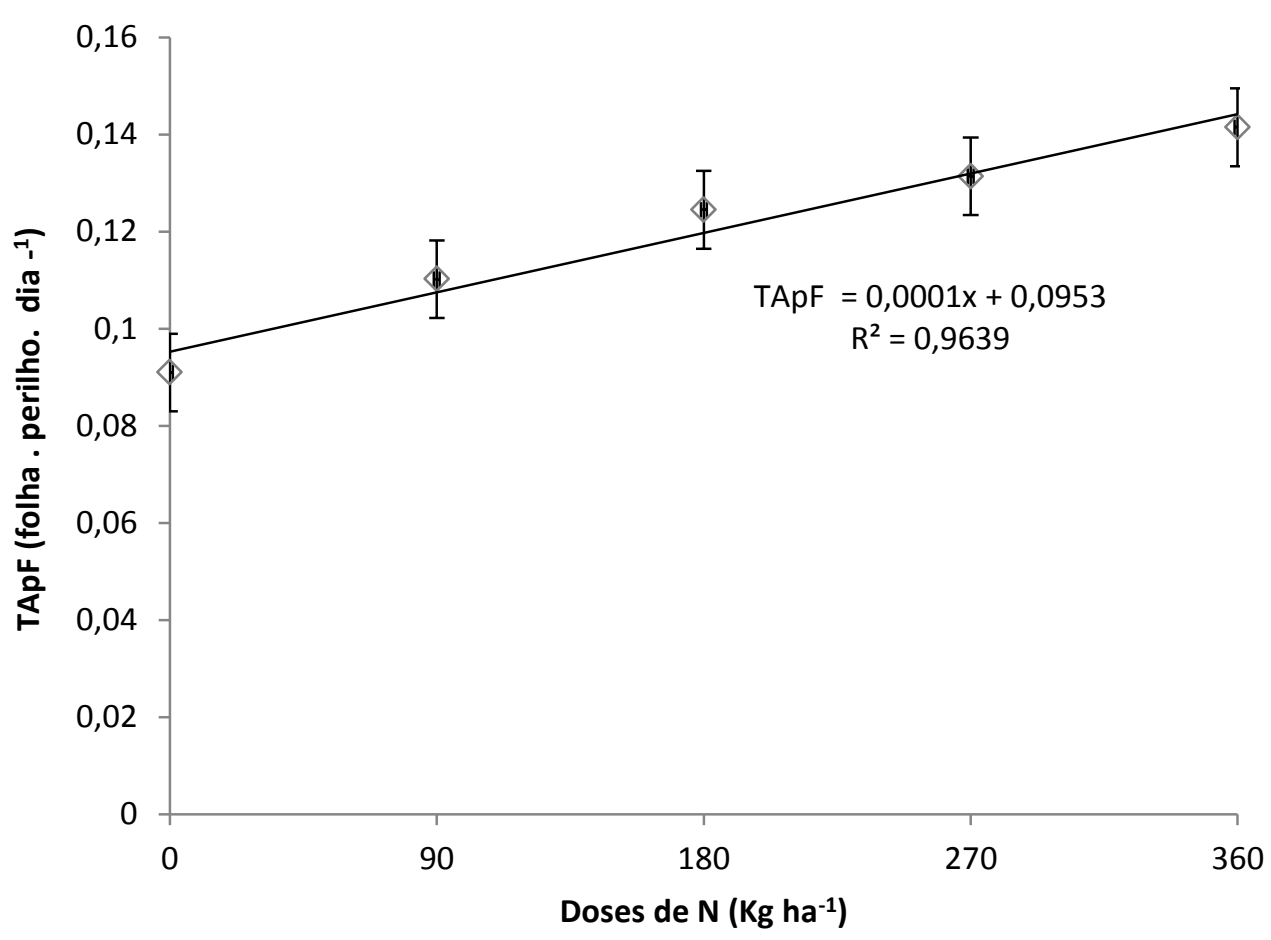

Figura 6. Taxa de aparecimento de folha (folha.perfilho ${ }^{-1} \cdot \mathrm{dia}^{-1}$ ) de Brachiaria brizantha cv. Marandu adubada com doses de N, considerando as médias dos ciclos de crescimento.

Para TApF verificou-se efeito linear ascendente da dose $0 \mathrm{~kg}$ de $\mathrm{N} \mathrm{ha}^{-1}$ para $360 \mathrm{~kg}$ de $\mathrm{N} \mathrm{ha}^{-1}$ da ordem de $65 \%$. Onde se registrou aparecimentos foliares de 0,14 folha.dia ${ }^{-1}$.perfilho ${ }^{-1}$. Esses valores vão de encontro ao que foi encontrado por Martuscello et al.(2005), que ao estudar Brachiaria brizantha cv. Xaraés, submetida a doses de $\mathrm{N}$, cultivada em casa de vegetação, obtiveram para a dose de 120 mg.dm ${ }^{-3}$ TApF de 0,121 folhas.dia ${ }^{-1}$. perfilho ${ }^{-1}$.

O Fil é o inverso da TApF, portanto teve comportamento linear descendente em relação as doses de $\mathrm{N}$ aplicadas. O Fil variou de 12,1 a 7,9 dias, quando a dose de $\mathrm{N}$ foi acrescida do controle em $360 \mathrm{~kg} \cdot \mathrm{ha}^{-1}$. Esse resultado é corroborado por pesquisa feito por Martuscello et al. (2005), que encontraram para o capim-xaraés resposta linear negativa com o acréscimo de nitrogênio, tanto para os dados expressos em dias como em graus-dia, variando de 11,5 e 8,8 dias, respectivamente entre o controle e $240 \mathrm{~kg}$ de N. ha ${ }^{-1}$.

Orrico Jr. et al. (2013), num experimento utilizando efluente de avicultura em Brachiaria brizantha cv. Piatã observaram Fil variando de 16,1 a 8,5 dias com 0 acréscimo de 250 kg.N.ha ${ }^{-1}$ a partir do controle. A ação do $\mathrm{N}$ foi relevante, uma vez 
que é considerado elemento para a recuperação do aparelho fotossintético, o que faz reduzir o tempo para o aparecimento de duas folhas consecutivas. Isso evidencia a importância do $\mathrm{N}$ em uma série de processos fisiológicos (NABINGER, 2001), inclusive no aparecimento foliar.

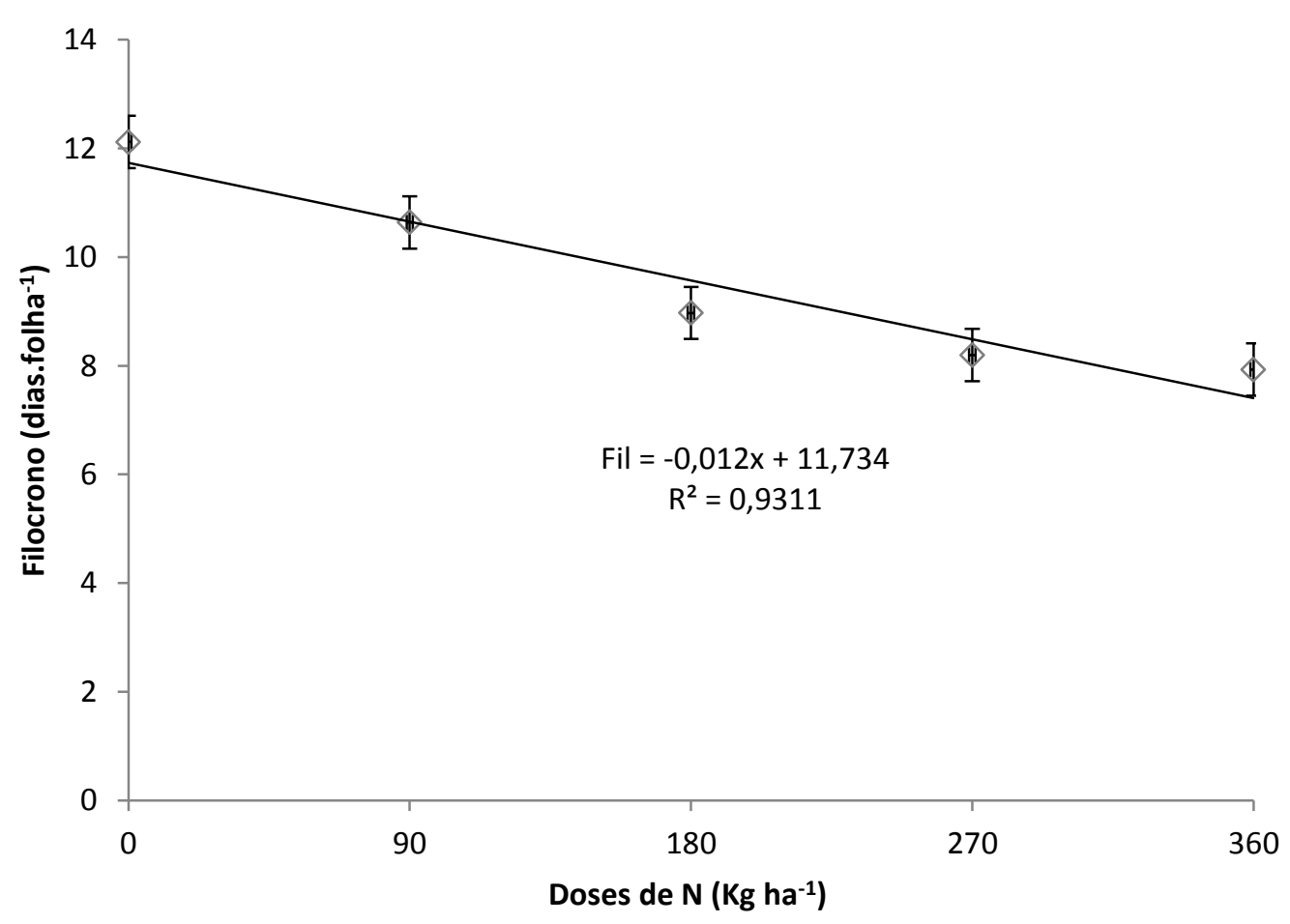

Figura 7. Filocrono (dias.folha-1 ${ }^{-1}$ ) de Brachiaria brizantha cv. Marandu adubada com doses de $\mathrm{N}$, considerando as médias dos ciclos de crescimento.

Ao observar a Tabela 4 verifica-se menor crescimento no $\mathrm{CC}_{3}$ (fevereiro/março de 2012), em decorrência do processo fenológico das plantas e das condições climáticas provavelmente relacionadas com o estádio fenológico da planta em estudo compreendendo sua fase de reprodução estar sendo iniciada nesse período. 
Tabela 4. Médias de taxa de alongamento foliar $\left(m m\right.$.perfilho ${ }^{-1} \cdot d^{-1} a^{-1}$ ), taxa de aparecimento foliar (folhas.perfilho ${ }^{-1} \cdot$ dia $^{-1}$ ) e filocrono (dias.folha ${ }^{-1}$ ) de Brachiaria brizantha cv. Marandu adubada com doses de N, considerando os ciclos de crescimento.

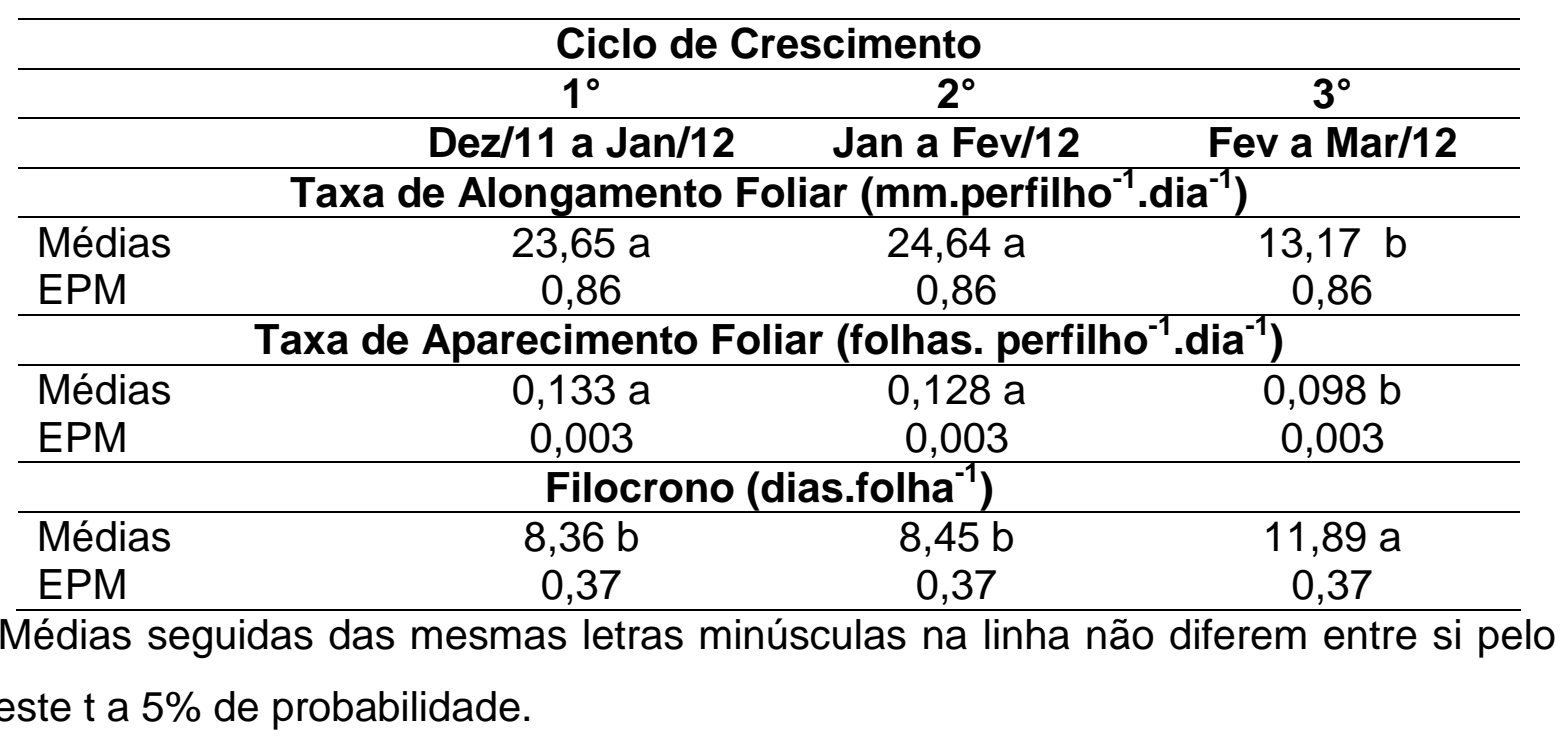

4.2.2. Número de folhas vivas, duração de vida da folha e taxa de alongamento de colmo.

Os dados médios para NFV, DVF, CFF e TAIC tiveram efeitos significativos para as doses de $\mathrm{N}$ e para os ciclos de crescimento (Tabela 5), porém não houve interação entre eles $(P<0.001)$. 
Tabela 5. Médias do número de folhas vivas, de duração de vida de folhas, de comprimento final de folhas e de taxa de alongamento de colmo de Brachiaria brizantha cv. Marandu adubada com doses de $\mathrm{N}$, considerando os ciclos de crescimento.

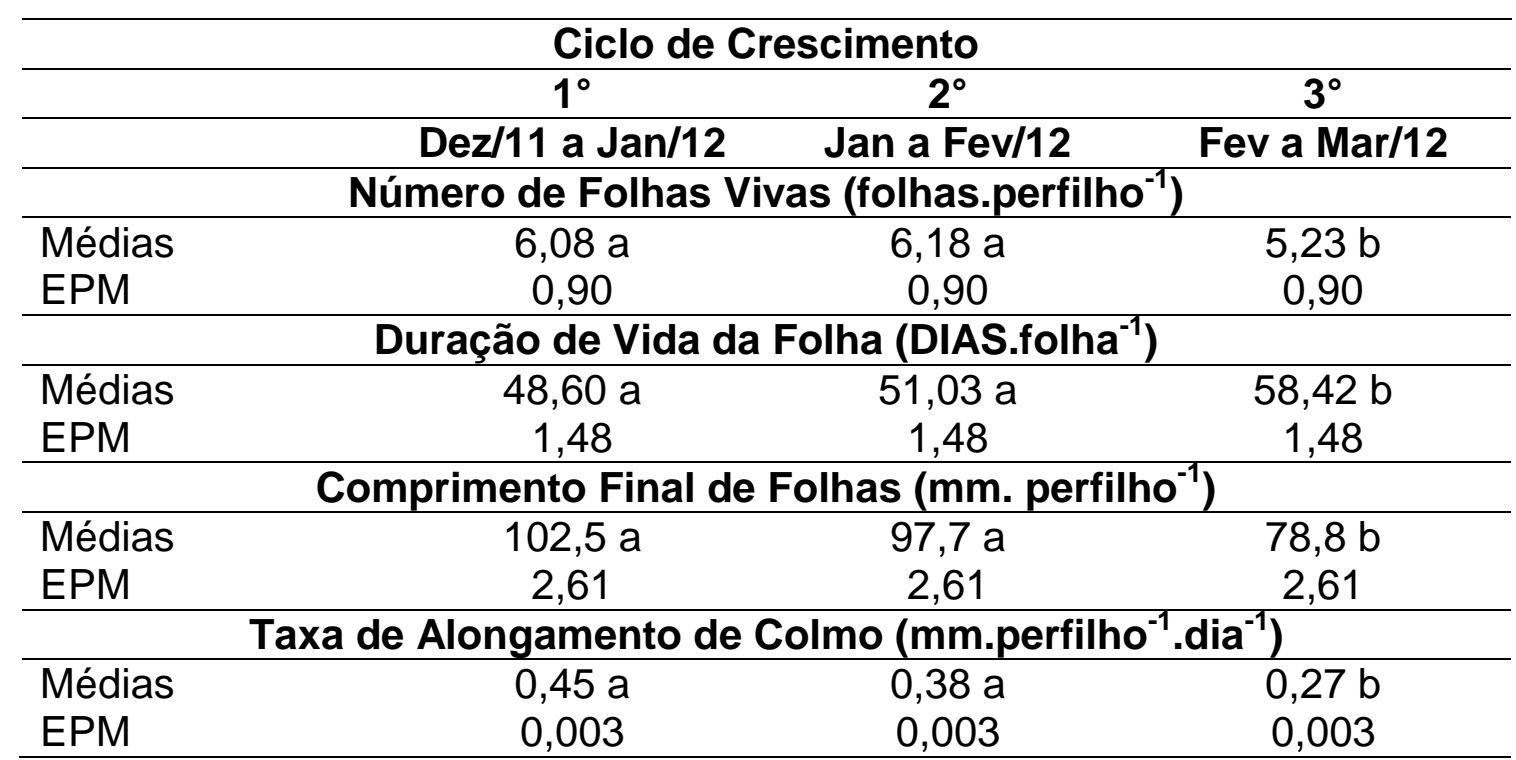

*Médias seguidas das mesmas letras minúsculas na linha não diferem entre si pelo teste $t$ a $5 \%$ de probabilidade.

O NFV (Figura 8) teve crescimento positivo em relação às doses de $\mathrm{N}$ aplicadas, sendo registradas 6,3 folhas.perfilho-1 para a dose de $360 \mathrm{~kg}^{-1 e} \mathrm{~N}$.ha- ${ }^{-1}$, aumento de $17 \%$ em relação a dose $0 \mathrm{~kg}$ de N.ha- ${ }^{-1}$. Este comportamento foi similar ao encontrado por Orrico Jr. et al. (2013), que em seu ensaio com a utilização de efluente de avicultura em Brachiaria brizantha cv. Piatã, encontraram NFV de 5,17 folhas.perfilho $^{-1}$, quando aplicaram $250 \mathrm{~kg} \cdot \mathrm{ha}^{-1} \mathrm{de} \mathrm{N}$, com o acréscimo de $36 \%$ comparado ao controle, enquanto Martuscello et al. (2005) verificaram para o capimxaraés resultado semelhante, 5,5 folhas.perfilho ${ }^{-1}$, para dose equivalente $(240 \mathrm{~kg}$.ha ${ }^{1}$ de N). 


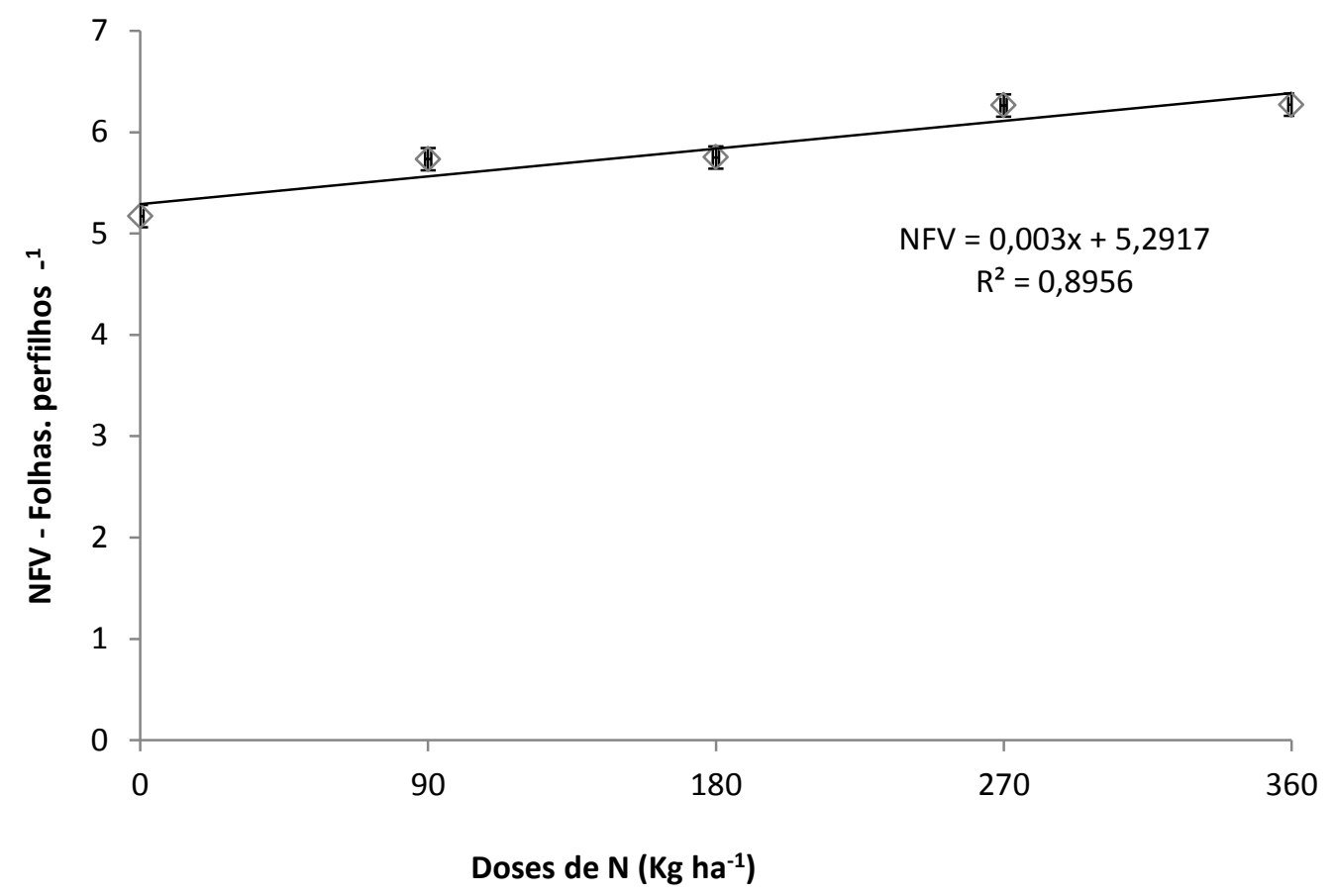

Figura 8. Número de folhas vivas de Brachiaria brizantha cv. Marandu adubada com doses de $\mathrm{N}$, considerando as médias dos ciclos de crescimento.

O NFV e o CFF, na composição da pastagem, determinam a quantidade máxima de tecido foliar verde que um perfilho acumula, que, associados ao número de perfilhos por área, contribuem para o IAF. Esta variável por sua vez é importante para a eficiência de absorção luminosa, a capacidade fotossintética do pasto e, consequentemente, para a produtividade da pastagem (LEMAIRE, 1997).

O NFV é resultante da DVF, portanto, constitui uma característica genotípica bastante estável na ausência de deficiências nutricionais (NABINGER, 2001). O aumento das doses de $\mathrm{N}$ para o capim-marandu promoveu diminuição no tempo de vida da folha (Figura 9). Isto acontece porque, segundo Nabinger e Pontes (2001), quando o perfilho apresenta seu número máximo de folhas vivas passa a haver equilíbrio entre a taxa de aparecimento e a de senescência de folhas em seu período de duração de vida. Por outro lado, a ausência da adubação nitrogenada favorece para maior permanência das folhas vivas em detrimento da expansão de novas folhas (MARTUSCELLO et al., 2005). 


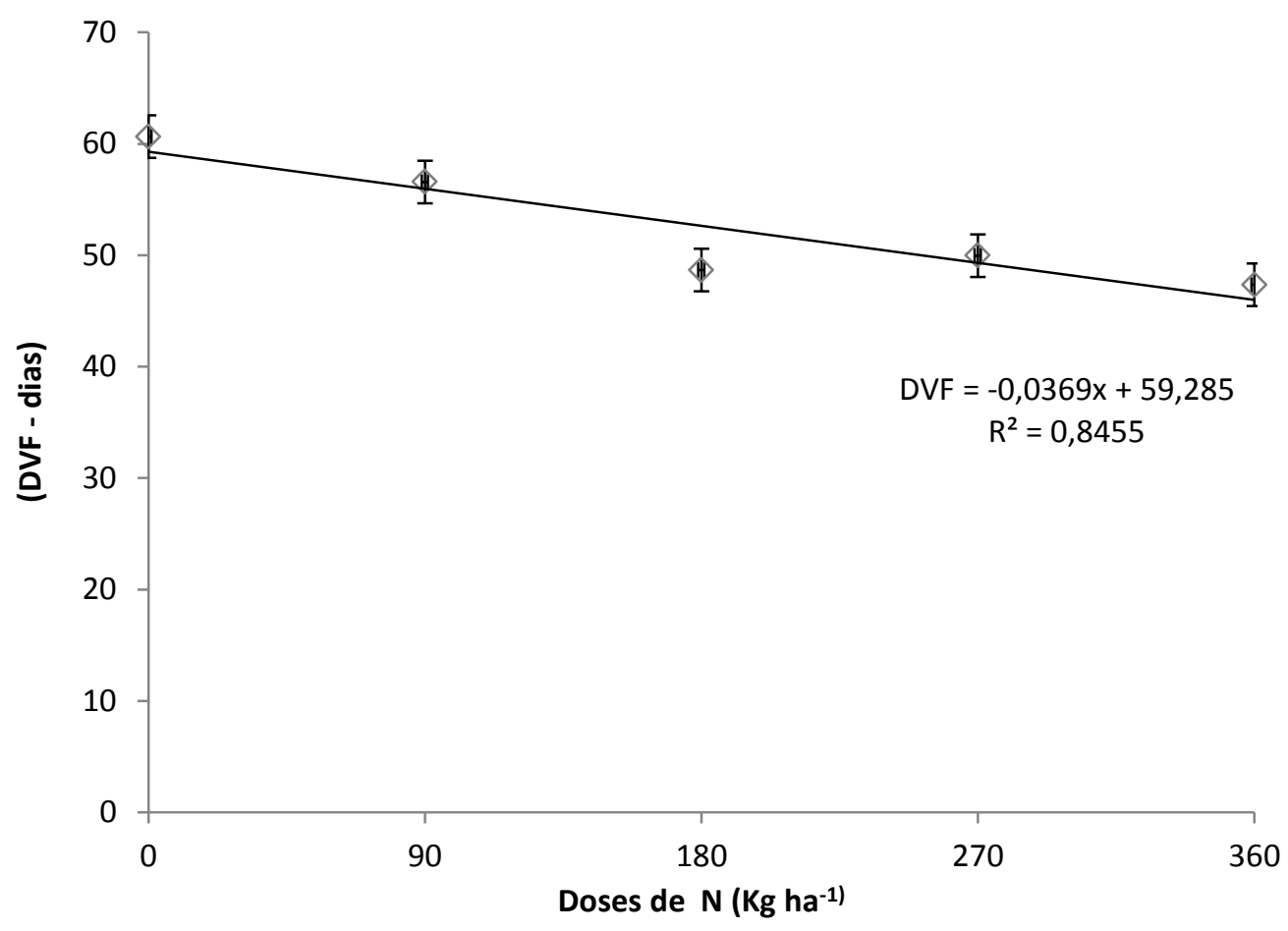

Figura 9. Duração de vida de folhas (Dias) de Brachiaria brizantha cv. Marandu, adubadas com doses de $\mathrm{N}$, considerando as médias dos ciclos de crescimento.

Nabinger (2001) menciona que o aumento de $\mathrm{N}$ deve ser concomitante com a taxa de lotação adequada e período de descanso em pastos rotativos, pois o manejo inadequado, utilizando este método, pode gerar o excesso de tecidos senescentes e diminuir o crescimento das plantas. Neste experimento, a DVF variou de 60,6 a 41,0 dias, considerando o aumento da adubação nitrogenada de 0 a $360 \mathrm{~kg}$ de N.ha-1.

Para o CFF (Figura 10) observou-se comportamento linear crescente com as doses de N, porém o encontrado por Marturcello et al. (2005) foi superior. Além do cultivar utilizado ser diferente do referido autor, o CFF encontrado neste estudo pode ser justificado devido à taxa de lotação adotada e do resíduo do pasto ter menor altura, pois esta variável pode ser modificada com a desfolha e estratégias de manejo do pasto, e está diretamente relacionada com TAIF e a TApF (LEMAIRE; CHAPMAN, 1996). 


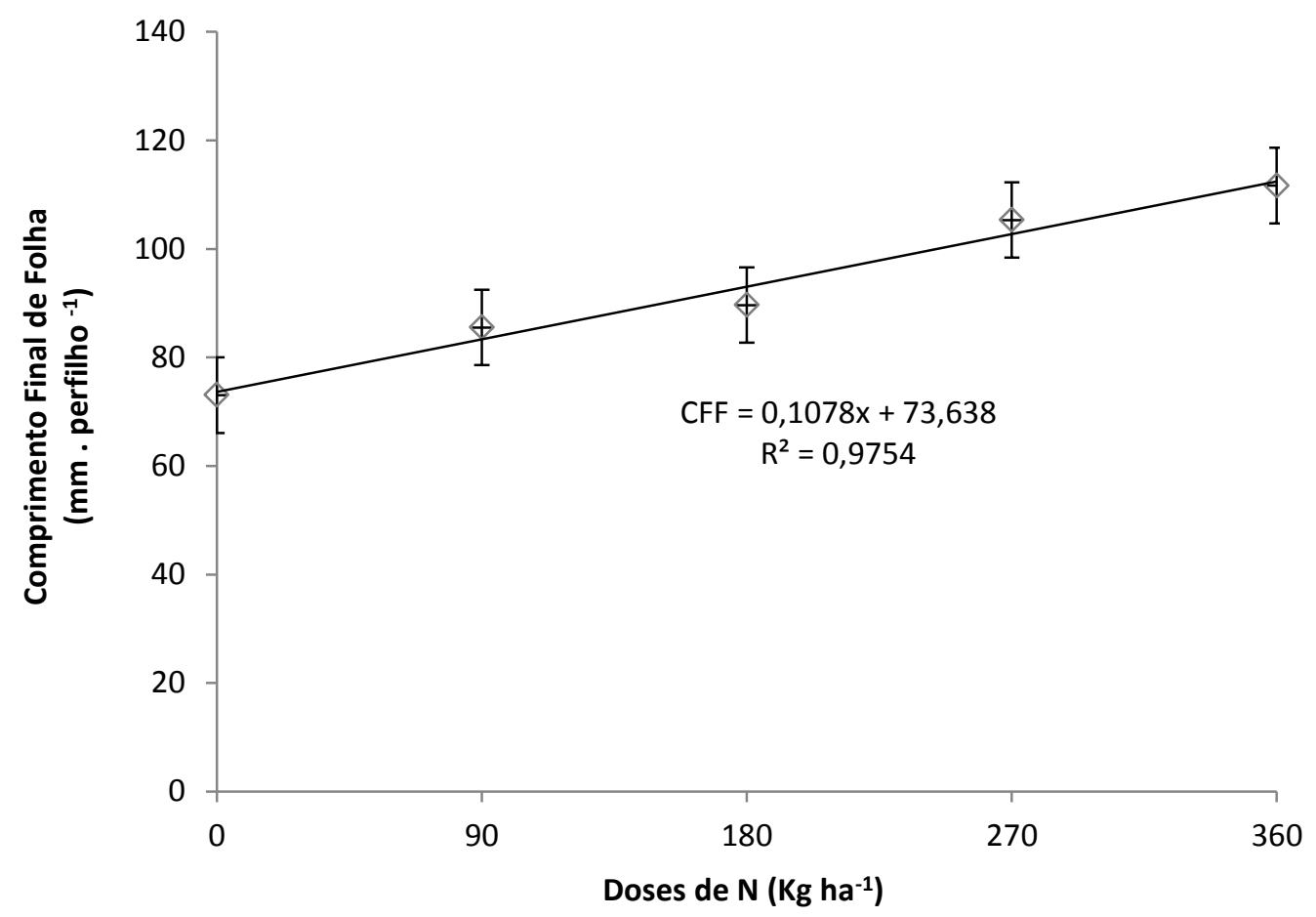

Figura 10. Comprimento final de folhas (mm.perfilho ${ }^{-1}$ ) de Brachiaria brizantha cv. Marandu, adubada com doses de $\mathrm{N}$, considerando as médias dos ciclos de crescimento.

Com o acréscimo de $\mathrm{N}$ até sua dose máxima $\left(360 \mathrm{~kg} \cdot \mathrm{ha}^{-1}\right)$ houve aumento em $65 \%$ no CFF $\left(111,2\right.$ mm.perfilhos $\left.{ }^{-1}\right)$, comparado aos dados médios do controle $(73,1$ mm.perfilho $\left.{ }^{-1}\right)$.

No terceiro ciclo de crescimento (fevereiro/março 2012) as variáveis NFV, DVF, e CFF apresentaram magnitudes de valores inferiores aos ciclos de crescimento anteriores. Este comportamento deveu-se ao estádio de crescimento da planta e a época de avaliação.

Para a TAIC (Figura 11) observou-se resultados lineares com a adição do $\mathrm{N}$, tendo variado de 0,30 a $0,46 \mathrm{~mm} \cdot \mathrm{dia}^{-1}$ para o tratamento controle e $360 \mathrm{~kg} \cdot \mathrm{ha}^{-1}$ de N respectivamente. Essas médias foram inferiores aos encontrados por outros autores, acompanhando, assim, o que ocorreu com CFF. Estas duas variáveis estão interligadas, devido ao comportamento morfológico (GOMIDE; GOMIDE, 1999). O CFF é afetado principalmente, pelo comprimento do pseudocolmo (envoltório de bainhas), que está relacionado com TAIC. Assim, quanto maior for esse comprimento, maior será o caminho percorrido pela folha ao completar sua emergência, determinando, portanto seu crescimento (CASAGRANDE et al., 2010). 


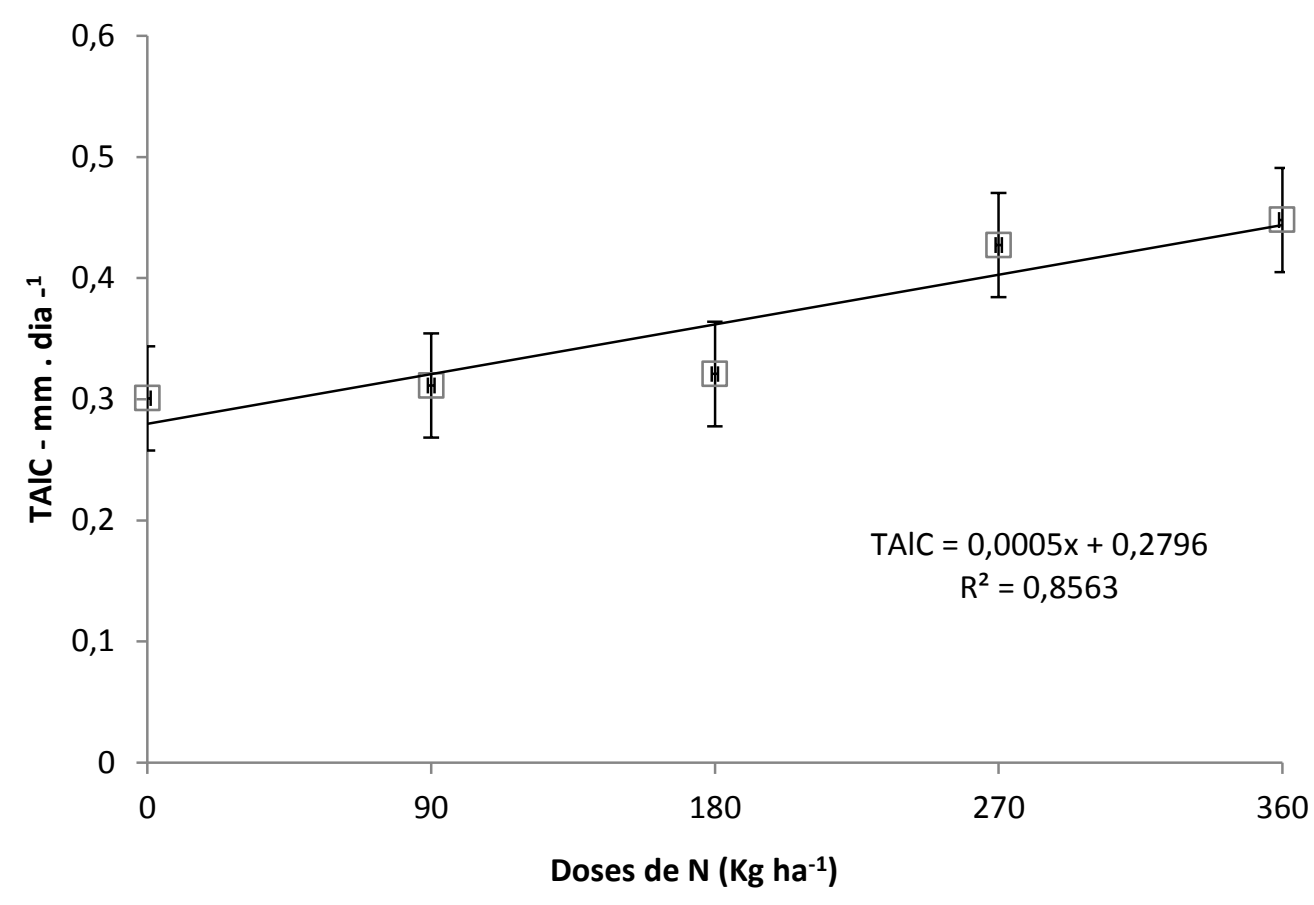

Figura 11. Taxa de alongamento de colmo (mm.perfilho ${ }^{-1} \cdot$ dia $^{-1}$ ) de Brachiaria brizantha cv. Marandu adubadas com doses de $\mathrm{N}$, considerando as médias dos ciclos de crescimento

A TAIC, além de afetar diretamente a Densidade Populacional de Perfilhos e o Comprimento Final de Folha, pode ser utilizada como indicador do controle ou não do acúmulo desse componente pelo manejo da pastagem, cujo crescimento constitui-se em característica desfavorável no sistema de produção em pasto, pois representa barreira física ao consumo voluntário dos animais em pastejo, afetando a capacidade de apreensão de forragem (HODGSON, 1990).

Em plantas forrageiras tropicais, a fração colmo, importante para 0 crescimento, interfere na estrutura do dossel e nos processos de competição por luz (FAGUNDES et al., 2005). Esta fração tem relação direta com a altura de pastejo.

\subsubsection{Taxa de aparecimento de perfilhos}

Para TApP foram observados resultados significativos para doses de $\mathrm{N}$ (Figura 12), e para ciclos de crescimento (Tabela 6) $(P<0,05)$, porém não ocorreu interação entre os dois fatores analisados $(P>0,05)$. 


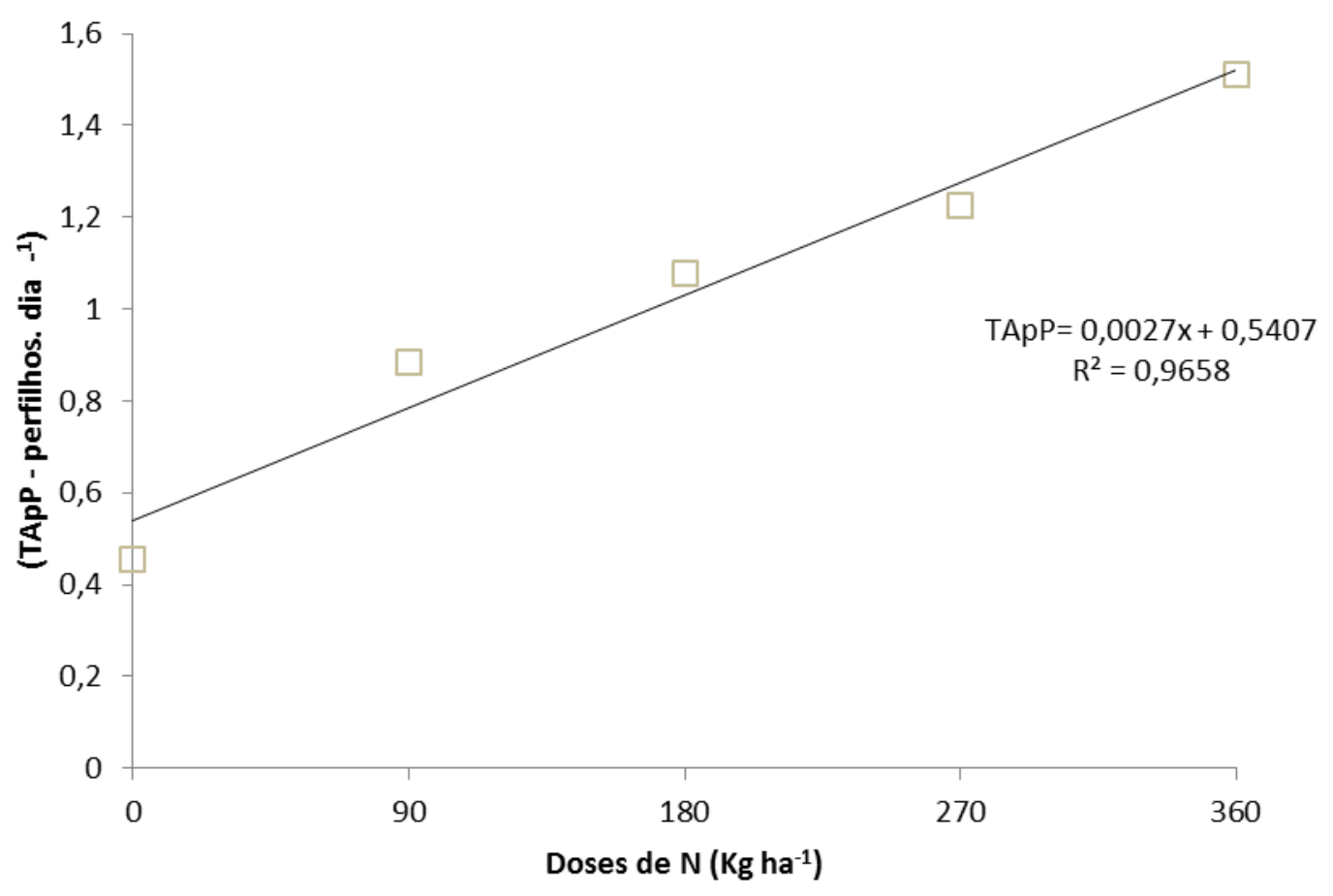

Figura 12. Taxa de aparecimento de perfilhos de Brachiaria brizantha cv. Marandu adubada com doses de $\mathrm{N}$, considerando as médias dos ciclos de crescimento.

A produção de massa por perfilho é dependente da TApF, da TAIF, do CFF e da DVF. No entanto, a produção de massa por área e a estrutura da pastagem dependem da densidade de perfilhos do pasto, assim o perfilhamento é quem determinará qual será a porcentagem de MS da pastagem (CABRAL et al., 2012)

Com a presença de $\mathrm{N}$ foi possível aumentar TApP de 0,48 perfilho. dia ${ }^{-1}$ para 1,51 perfilho.dia ${ }^{-1}$, considerando as doses 0 e $360 \mathrm{~kg} \mathrm{ha}^{-1}$ de $\mathrm{N}$, respectivamente.

4.2.4 Densidade populacional de perfilhos e taxa de senescência foliar

Para as variáveis DPP e TSF não houve efeitos significativos para doses de N. Somente ocorreu significância para o ciclo de crescimento $(P<0,001)$, Tabela 6. 
Tabela 6. Médias de densidade populacional de perfilhos, taxa de senescência foliar e taxa de aparecimento de perfilhos de Brachiaria brizantha cv. Marandu adubada com doses de $\mathrm{N}$, considerando os ciclos de crescimento.

\begin{tabular}{|c|c|c|c|}
\hline \multicolumn{4}{|c|}{ Ciclo de Crescimento } \\
\hline & $1^{\circ}$ & $2^{\circ}$ & $3^{\circ}$ \\
\hline & Dez/11 a Jan/12 & Jan a Fev/12 & Fev a Mar/12 \\
\hline \multicolumn{4}{|c|}{ Densidade Populacional de Perflhos (perfilho. ${ }^{-2}$ ) } \\
\hline Médias & $519 \mathrm{c}$ & $915 \mathrm{a}$ & $748 \mathrm{~b}$ \\
\hline EPM & 54,68 & 54,68 & 54,68 \\
\hline \multicolumn{4}{|c|}{ Taxa de Aparecimento de Perfilhos (perfilho ${ }^{-1}$. dia $^{-1}$ ) } \\
\hline Médias & $0,86 \mathrm{~b}$ & $1,61 \mathrm{a}$ & $0,61 \mathrm{c}$ \\
\hline EPM & 0,14 & 0,14 & 0,14 \\
\hline \multicolumn{4}{|c|}{ Taxa de Senescencia Foliar ( mm. perfilho-1. dia $\left.{ }^{-1}\right)$} \\
\hline Médias & $0,76 \mathrm{a}$ & $0,03 \mathrm{~b}$ & $0,04 \mathrm{c}$ \\
\hline EPM & 0,13 & 0,13 & 0,13 \\
\hline
\end{tabular}

Os resultados obtidos para TSF pode ser explicado pelo manejo da pastagem. Os animais permaneciam em pastejo por 5 dias e, após sua saída 0 pasto permanecia em descanso por 25 dias. $\mathrm{Na}$ entrada, o pasto apresentava, em média $16 \mathrm{~cm}$ de altura e na saída $6 \mathrm{~cm}$. Como as condições edafoclimáticas eram adequadas para o cultivar Marandu, a renovação de tecidos era constante, o que favoreceu diminuir o material senescente no pasto, o que não é possível ocorrer em áreas onde o pastejo não é realizado (HODGSON, 1990).

Difante et al. (2011), ao trabalharem com alturas de corte do capim-marandu encontraram que as plantas manejadas a $15 \mathrm{~cm}$ apresentaram menor taxa de senescência foliar que aquelas a $30 \mathrm{~cm}\left(0,62\right.$ e $1,19 \mathrm{~mm} \cdot$ perfilho $^{-1} \cdot \mathrm{dia}^{-1}$, respectivamente) característica que está associada diretamente ao acúmulo de material morto, redução da eficiência de colheita e do valor nutritivo da forragem produzida (Carnevalli et al., 2006). Estes resultados apresentados corroboram apenas com as médias encontradas no $\mathrm{CC}_{1}$, quando manejado com $15 \mathrm{~cm}$ de resíduo. Nos $\mathrm{CC}_{2}$ e $\mathrm{CC}_{3}$, ainda o capim-marandu se apresentando vegetativo, as perdas por senescência foram muito baixas $\left(0,04\right.$ e $0,03 \mathrm{~mm}$. perfilho $\left.{ }^{-1} \cdot \mathrm{dia}^{-1}\right)$, respectivamente.

Fagundes et al. (2005), num estudo variando dose de N, constataram para Brachiaria decumbens que a TSF não foi afetada pelo $\mathrm{N}$ aplicado, e os autores 
mencionam que este comportamento pode ser atribuído à uniforme manutenção de altura do pasto em $20 \mathrm{~cm}$, independente da dose de $\mathrm{N}$, resultado esse similar ao encontrado neste experimento para as TSF.

Alexandrino, Vaz e Santos (2010) não obtiveram resultado significativo para DPP em pesquisa realizada com o capim-marandu sob pastejo e doses de $\mathrm{N}$ de 0 a $160 \mathrm{mg} \cdot \mathrm{dm}^{-3}$. Este comportamento antagônico ao mencionado na literatura, segundo os autores, justifica-se às diferentes ofertas de forragem utilizadas com taxas de lotação semelhantes, porém, pode ter ocorrido a renovação desuniforme de tecido celular. O mesmo comportamento foi encontrado por Fagundes et al. (2005), estudando Brachiaria decumbens sob doses de N. Os efeitos foram significativos apenas para as estações do ano.

\subsubsection{Composição morfológica}

Para a composição morfológica houve efeitos significativos de doses de $\mathrm{N}$ na participação percentual de lâmina foliar, colmo + bainha e material morto (figura 13). Para os ciclos de crescimento houve efeito apenas para a participação percentual de lâmina foliar e material morto (tabela 7), porém não ocorreu interação entre os dois fatores analisados $(P>0,001)$.

Tabela 7. Participação percentual média de lâmina foliar e de material morto de Brachiaria brizantha cv. Marandu adubada com doses de N, considerando os ciclos de crescimento.

\begin{tabular}{|c|c|c|c|}
\hline \multicolumn{4}{|c|}{ Ciclo de Crescimento } \\
\hline & $1^{\circ}$ & $2^{\circ}$ & $3^{\circ}$ \\
\hline & Dez/11 a Jan/12 & Jan a Fev/12 & Fev a Mar/12 \\
\hline \multicolumn{4}{|c|}{ Lâmina Foliar (\%) } \\
\hline Médias & $53,89 \mathrm{~b}$ & $60,51 \mathrm{a}$ & $43,87 \mathrm{c}$ \\
\hline EPM & 1,022 & 1,022 & 1,022 \\
\hline \multicolumn{4}{|c|}{ Material Morto (\%) } \\
\hline Médias & $27,89 \mathrm{~b}$ & $19,48 \mathrm{c}$ & $35,56 \mathrm{a}$ \\
\hline EPM & 0,947 & 0,947 & 0,947 \\
\hline
\end{tabular}

*Médias seguidas das mesmas letras minúsculas na linha não diferem entre si pelo teste $t$ a $5 \%$ de probabilidade. 


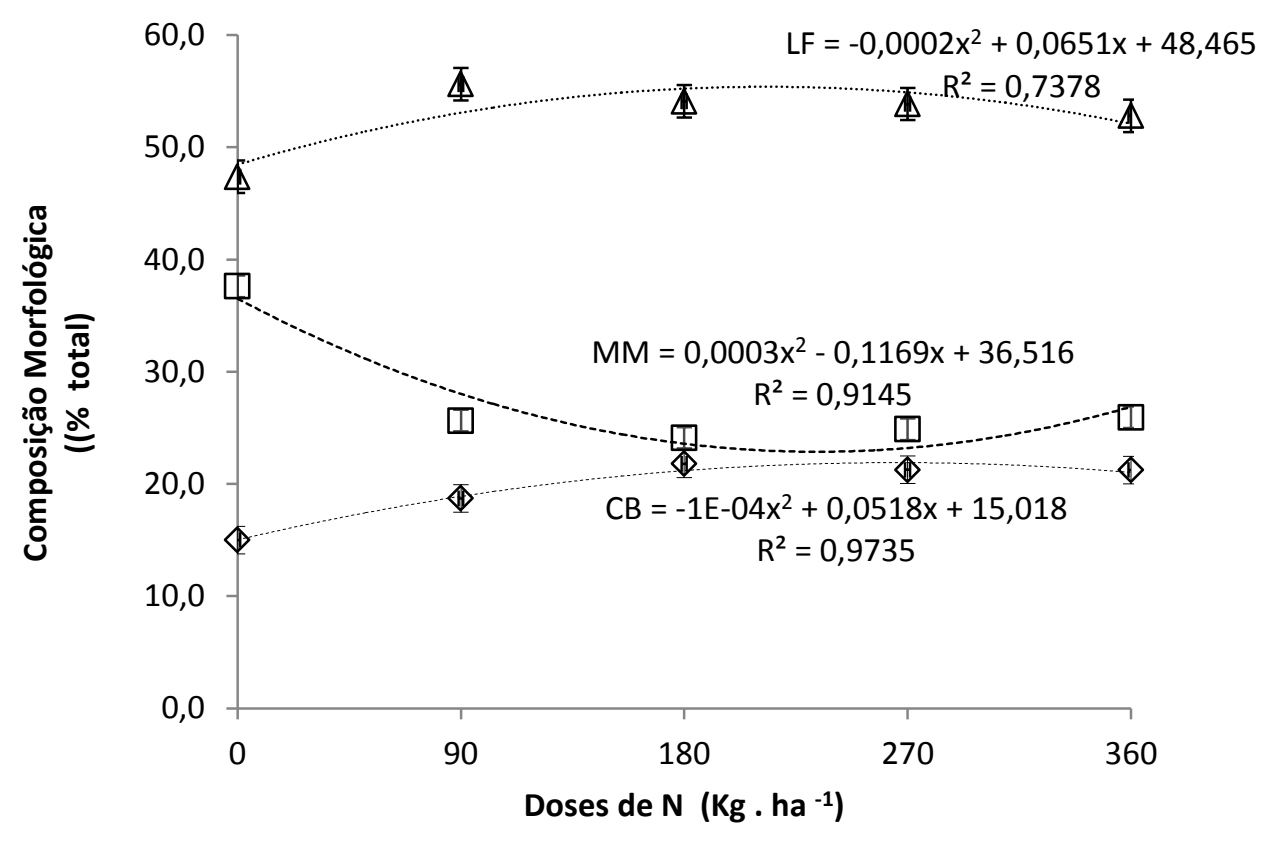

Figura 13. Composição morfológica de Brachiaria brizantha cv. Marandu adubada com doses de $\mathrm{N}$, considerando as médias dos ciclos de crescimento.

Houve resposta quadrática às doses de $\mathrm{N}$, mesmo comportamento verificado para a massa seca de forragem. Observa-se que ocorreu aumento de $L F$, e queda concomitante de MM na composição do pasto. Embora inferior, a massa de CB acompanhou o comportamento de massa de lâminas foliares. É natural em doses elevadas de $\mathrm{N}$, com o aumento de lâminas foliares e com a elevação do colmo, o auto-sombreamento sendo acompanhado de ligeiro aumento do MM, o que ocorreu na maior dose de N. Pode estar associado a isto, também, a baixa eficiência de utilização da forragem produzida com 0 aumento da adubação nitrogenada (EUCLIDES et al., 1998), uma vez que a participação de colmos e lâminas foliares encontrava-se em queda

Fagundes et al. (2006), em pesquisa durante 4 estações climáticas com Brachiaria decumbens sob pastejo e doses crescentes de $\mathrm{N}$, observaram grande acúmulo de MM, CB e LF da ordem de 32,5; 44,5 e 23,0\%, respectivamente para a dose de $300 \mathrm{~kg} \cdot \mathrm{ha}^{-1}$ de $\mathrm{N}$ no verão. Na presente pesquisa os melhores resultados foram da ordem de $24,9 \%$ para $M M, 21,8 \%$ para $C B$, e $53,3 \%$ para $L F$, sendo 
contrastantes aos observados por Fagundes et al. (2006) e da ordem de $23 \%$ e $51 \%$ menos perda por senescência e CB, respectivamente, e 132\% mais lâmina foliar. Este comportamento aconteceu devido manejo do pastejo imposto, o que ajudou para a renovação de tecidos vegetais.

\subsection{EFICIÊNCIA DO USO DO NITROGÊNIO}

Para a EUN, houve efeito significativo apenas para doses de $N(P<0,02)$. $O$ comportamento foi linear negativo com o aumento das doses de N (Figura 14).

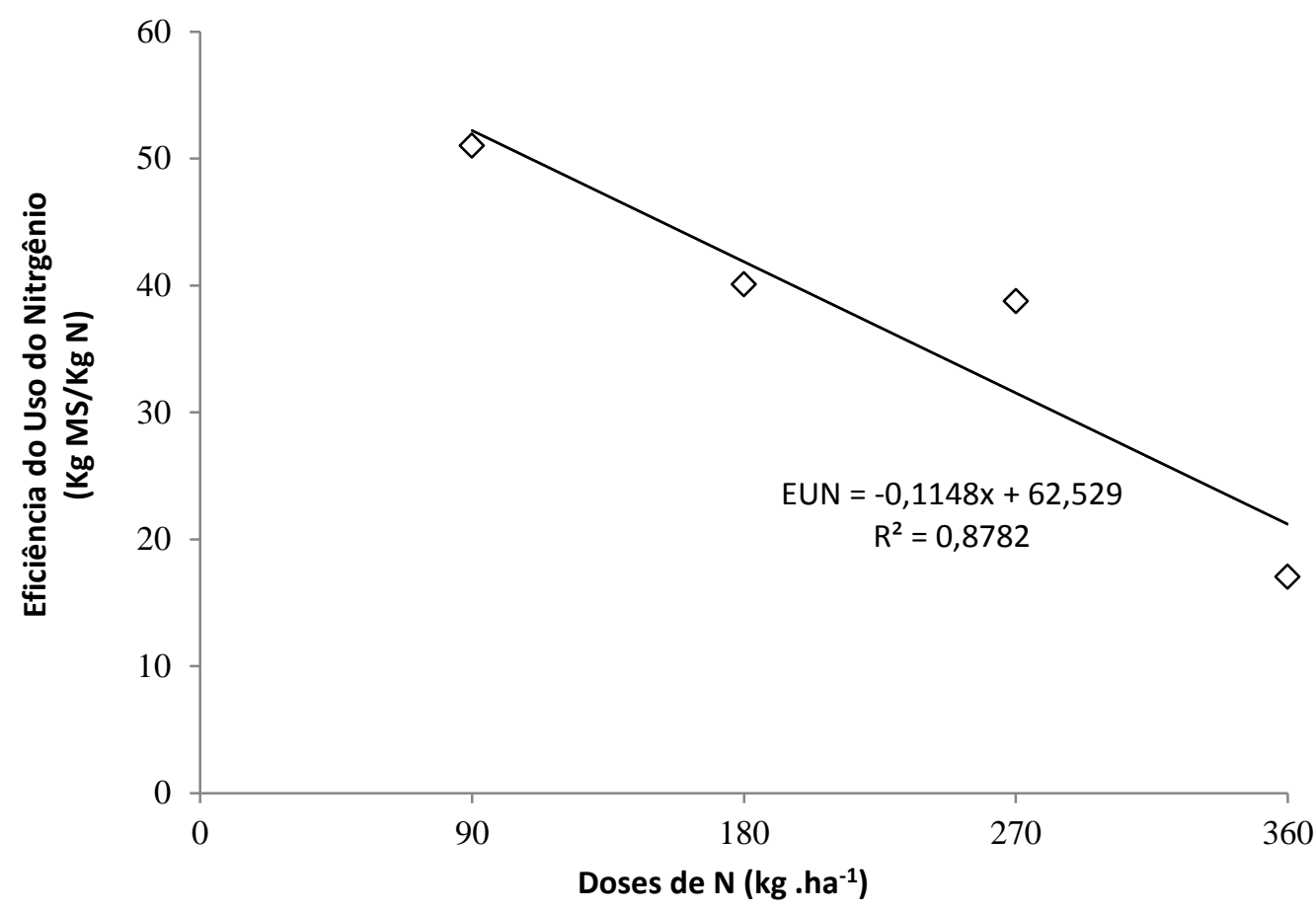

Figura 14. Eficiência de uso do N por Brachiaria brizantha cv. Marandu adubada com doses de $\mathrm{N}$, considerando o acúmulo do período experimental.

Essa variável é importante para determinar a capacidade de utilização do $\mathrm{N}$ disponível no solo pela planta na PMS. O estudo da EUN em sistemas produtivos é fundamental, pois à medida que a quantidade aplicada ultrapassa a capacidade da planta em absorver, metabolizar e transformar o nutriente em massa de forragem, o $\mathrm{N}$ pode ser perdido por lixiviação e ou volatilização, ou mesmo acumular-se nos tecidos, reduzindo sua eficiência de aproveitamento (DOUGHERTY; RHYKERD, 1985). 
Observou-se queda na eficiência de utilização do $\mathrm{N}$ com o aumento da dose do elemento. As EUN variaram de 51 a $17,1 \mathrm{~kg} \mathrm{MS} \mathrm{kg}^{-1}$ de N. Em média a EUN foi

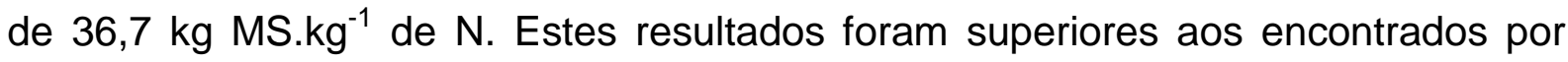
Castagnara et al. (2011), quando avaliaram os cultivares Tanzânia e Mombaça de

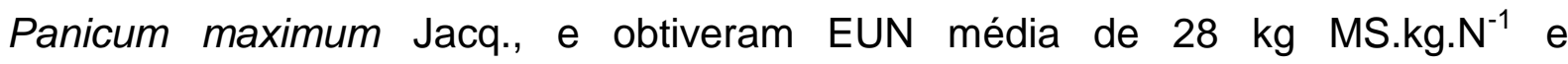
consideraram $108 \mathrm{~kg} \mathrm{~N} \mathrm{ha}^{-1}$ como a melhor dose aplicada, enquanto que neste experimento $90 \mathrm{~kg} / \mathrm{ha}$ de $\mathrm{N}$ pode ser considerada a melhor dose aplicada. .Fagundes et al. (2005) reportaram resultados com Brachiaria decumbens superiores aos encontrados no presente experimento, exceto pelo comportamento linear negativo. A EUN foi de $57 \mathrm{Kg} \mathrm{MS} . \mathrm{kg} \mathrm{N}^{-1}$ para a dose de $75 \mathrm{~kg}$ de N , enquanto que no

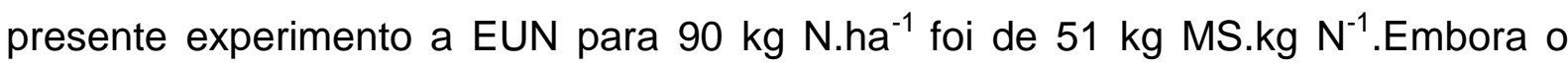
efeito do $\mathrm{N}$ no incremento de produção seja relevante, é preciso considerar que a produção de forragem não constitui a única característica a ser avaliada para considerar o potencial de uma planta forrageira.

\subsection{COMPOSIÇÃO BROMATOLÓGICA}

\subsubsection{Proteína bruta}

Houve efeitos significativos $(P<0,05)$ de doses de $\mathrm{N}$ e ciclos de crescimento para os teores de proteína bruta da lâmina foliar (PBLF\%) e de colmo e bainha (PBCB\%) (Tabela 8), sem efeito para a interação dos fatores $(P>0,05)$. $O$ teor de proteína bruta da planta inteira (PBPI\%) teve influência significativa $(P<0,001)$ apenas para doses de $\mathrm{N}$. 
Tabela 8. Teores médios de proteína bruta na lamina foliar, planta inteira e colmo e bainha de Brachiaria brizantha cv. Marandu adubada com doses de $\mathrm{N}$, considerando os ciclos de crescimento.

\begin{tabular}{|c|c|c|c|}
\hline \multicolumn{4}{|c|}{ Ciclo de Crescimento } \\
\hline & $1^{\circ}$ & $2^{\circ}$ & $3^{\circ}$ \\
\hline & Dez/11 a Jan/12 & Jan a Fev/12 & Fev a Mar/12 \\
\hline \multicolumn{4}{|c|}{ Proteína Bruta da Lâmina Foliar } \\
\hline Médias & $16,06 \mathrm{~b}$ & $15,40 \mathrm{~b}$ & $16,57 \mathrm{a}$ \\
\hline EPM & 0,303 & 0,303 & 0,303 \\
\hline \multicolumn{4}{|c|}{ Proteína Bruta da Planta Inteira } \\
\hline Médias & $13,12 \mathrm{a}$ & $12,85 \mathrm{a}$ & $12,26 \mathrm{a}$ \\
\hline EPM & 0,39 & 0,39 & 0,39 \\
\hline \multicolumn{4}{|c|}{ Proteína Bruta do Colmo e Bainha } \\
\hline Médias & $7,54 \mathrm{~b}$ & $7,78 \mathrm{~b}$ & $8,64 a$ \\
\hline EPM & 0,384 & 0,384 & 0,384 \\
\hline
\end{tabular}

Para as variáveis PBPI\% e PBLF\%, com o aumento das doses de $\mathrm{N}$, observou-se comportamento quadrático. No entanto, não se verificou o ponto de máximo teor proteico, tanto na planta inteira quanto na lâmina foliar, na dosagem máxima utilizada. Os pontos de máxima, pela derivação das equações situam-se em 493 e 421 kg.ha-1 de N. Para os teores de proteína bruta na porção colmo e bainha, o efeito foi linear, sendo que para cada $1 \mathrm{~kg} \cdot \mathrm{ha}^{-1}$ de $\mathrm{N}$ aplicado ocorreu acréscimo da ordem de $2 \%$ nos teores de PB, considerando o tratamento controle $(3,14 \%)$, Figura 15. Em ordem decrescente de teores de proteína bruta, as da LF foi superior à PI, que por sua vez foram superiores aos teores do CB. Como o $\mathrm{N}$ é parte integrante de enzimas nos tecidos fotossintetizantes, obteve-se maiores teores na ordem apresentada. Mesmo porque nas lâminas foliares é que se encontram as enzimas ribulose difosfato-carboxilase e a fosfoenolpiruvato-carboxilase (SANTOS et al., 2004), responsáveis pela fixação de carbono na fotossíntese, e este processo ocorre, principalmente, nas células do mesofilo foliar (CORSI; NASCIMENTO Jr., 1994). 


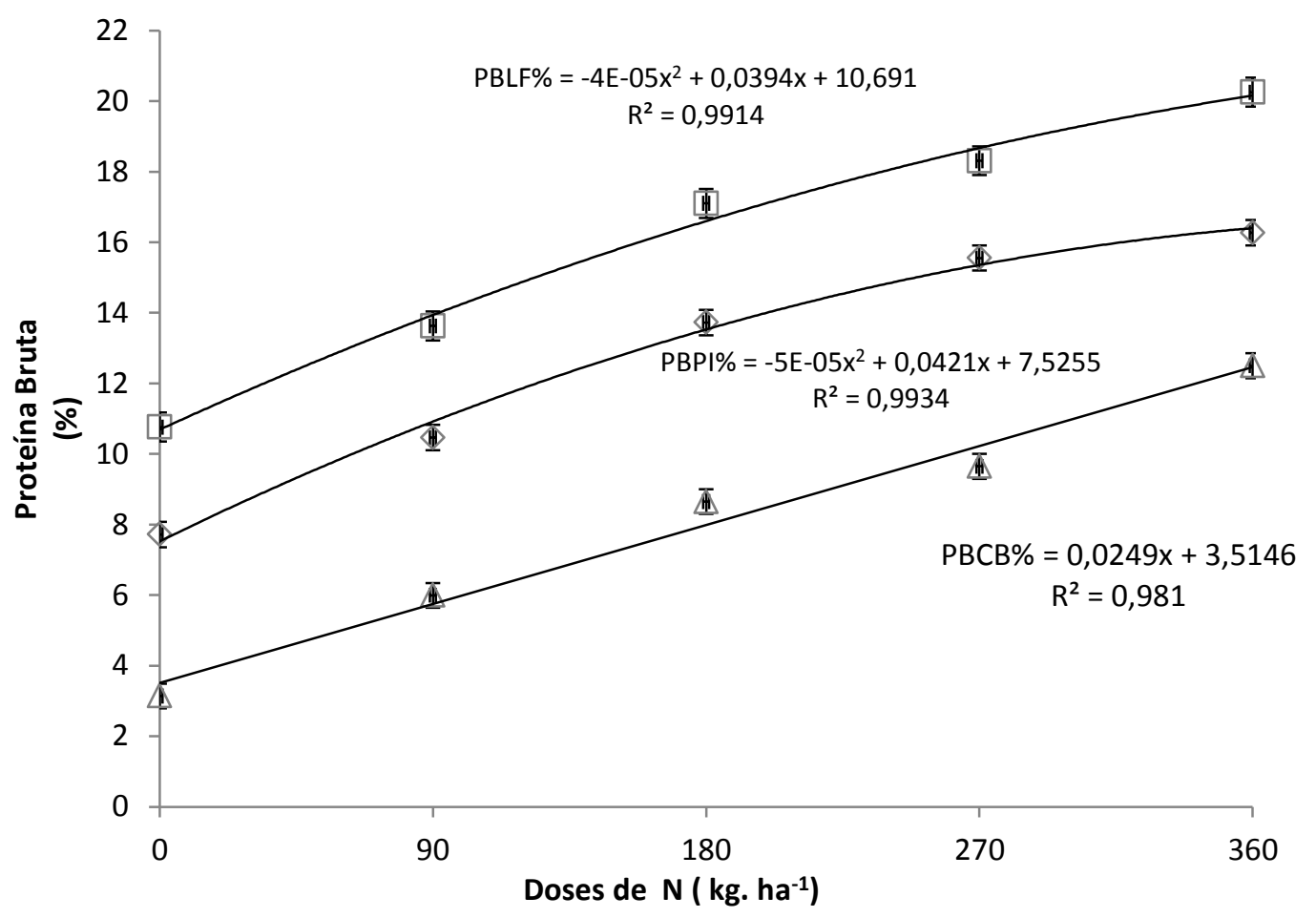

Figura 15. Teores de proteína bruta nas partes da planta de Brachiaria brizantha cv. Marandu adubada com doses de $\mathrm{N}$, considerando as médias dos ciclos de crescimento.

Santos et al. (2009), avaliando o capim-braquiária sob doses de $\mathrm{N}$ e diferida, observaram aumento linear no teor de PB dos tecidos vegetais, sendo as maiores concentrações encontradas em ordem decrescente: verdes, mortos, colmo verdes e colmo mortos, sendo observado a melhor qualidade do material analisado folhas verdes, folhas mortas, colmos verdes e colmos mortos. Na maior dose de $\mathrm{N}$ (120 $\mathrm{kg} \mathrm{ha}^{-1}$ ), os autores encontraram teor de PBLF\% da ordem de 8,3\%, teor inferior ao observado no presente experimento, principalmente em decorrência da espécie forrageira, método de pastejo e período de descanso pelo diferimento de 70 dias. Esse comportamento serve de orientação para o bom manejo da adubação e do pastejo, sendo necessário dar preferência às folhas na dieta dos animais em pastejo, em detrimento às partes mortas e lignificadas (HODGSON, 1990).

Euclides et al. (2009), num estudo comparativo utilizando cultivares de Brachiaria brizantha, encontraram teores de PBLF\% e PBCB\% da ordem de 8,3 e $4,7 \%$, respectivamente, sendo considerados superiores em relação ao CB $(3,14 \%)$ e inferiores à LF $(10,8 \%)$ em relação ao controle desta pesquisa. No estudo atual, os 
teores de PBLF\% e PBCB\% para a dose de $360 \mathrm{~kg}$ de N.ha ${ }^{-1}$ respectivamente 20,3 e $12,5 \%$ de PB.

Costa et al. (2013), avaliando fontes e doses de $\mathrm{N}$ aplicados em capimxaraés, constataram teores de PBPI\% da ordem de 16,3\% para a dose de $400 \mathrm{~kg}$ de $\mathrm{N} . h a^{-1}$. Esses resultados corroboraram com o atual estudo onde para a dose de 360 kg. N.ha- ${ }^{-1}$, apresentou teores de $16,3 \%$ de PBPI\%.

\subsubsection{Fibra em detergente neutro}

Efeitos significativos $(\mathrm{P}<0,001)$ de doses de $\mathrm{N}$ e ciclos de crescimento foram observados para os teores de FDN na PI e CB (Tabela 9), e da interação doses de N e ciclos de crescimento para os teores de FDN na LF $(P<0,01)$. Segundo Van Soest (1994), é na parede celular que se encontram a celulose e a hemicelulose, mais importantes para o metabolismo ruminal, dando assim sua real importância para a qualidade nutricional do alimento.

Tabela 9. Teores médios de fibra em detergente neutro na planta inteira e colmo e bainha de Brachiaria brizantha cv. Marandu adubada com doses de $\mathrm{N}$, considerando os ciclos de crescimento.

\begin{tabular}{|c|c|c|c|}
\hline \multicolumn{4}{|c|}{ Ciclo de Crescimento } \\
\hline & $1^{\circ}$ & $2^{\circ}$ & $3^{\circ}$ \\
\hline & Dez/11 a Jan/12 & Jan a Fev/12 & Fev a Mar/12 \\
\hline & \multicolumn{3}{|c|}{ FDN da Colmo e Bainha } \\
\hline Médias & $65,54 \mathrm{~b}$ & $69,06 \mathrm{a}$ & $61,12 \mathrm{c}$ \\
\hline EPM & 0,583 & 0,583 & 0,583 \\
\hline \multicolumn{4}{|c|}{ FDN da Planta Inteira } \\
\hline $\begin{array}{l}\text { Médias } \\
\text { EPM }\end{array}$ & $\begin{array}{c}57,55 \mathrm{~b} \\
0,594\end{array}$ & $\begin{array}{c}63,23 \mathrm{a} \\
0,594\end{array}$ & $\begin{array}{c}61,95 \mathrm{~b} \\
0,594\end{array}$ \\
\hline
\end{tabular}

* Médias seguidas das mesmas letras minúsculas na linha não diferem entre si pelo teste $t$ a $5 \%$ de probabilidade.

Como aumento na dose de $\mathrm{N}$ ocorreu decréscimo nos teores de fibra em detergente neutro da planta inteira (FDNPI\%) e de fibra em detergente neutro no colmo e bainha (FDNCB\%), sendo os comportamentos quadrático e linear, respectivamente (Figura 16). Esta redução nos teores de FDN é importante para melhorar o valor nutricional da forragem e o aumento do consumo de MSF pelos 
animais, uma vez que o teor de FDN é importante para definir a qualidade da forragem, tanto como limitar a capacidade de consumo dos animais (COSTA et al., 2010).

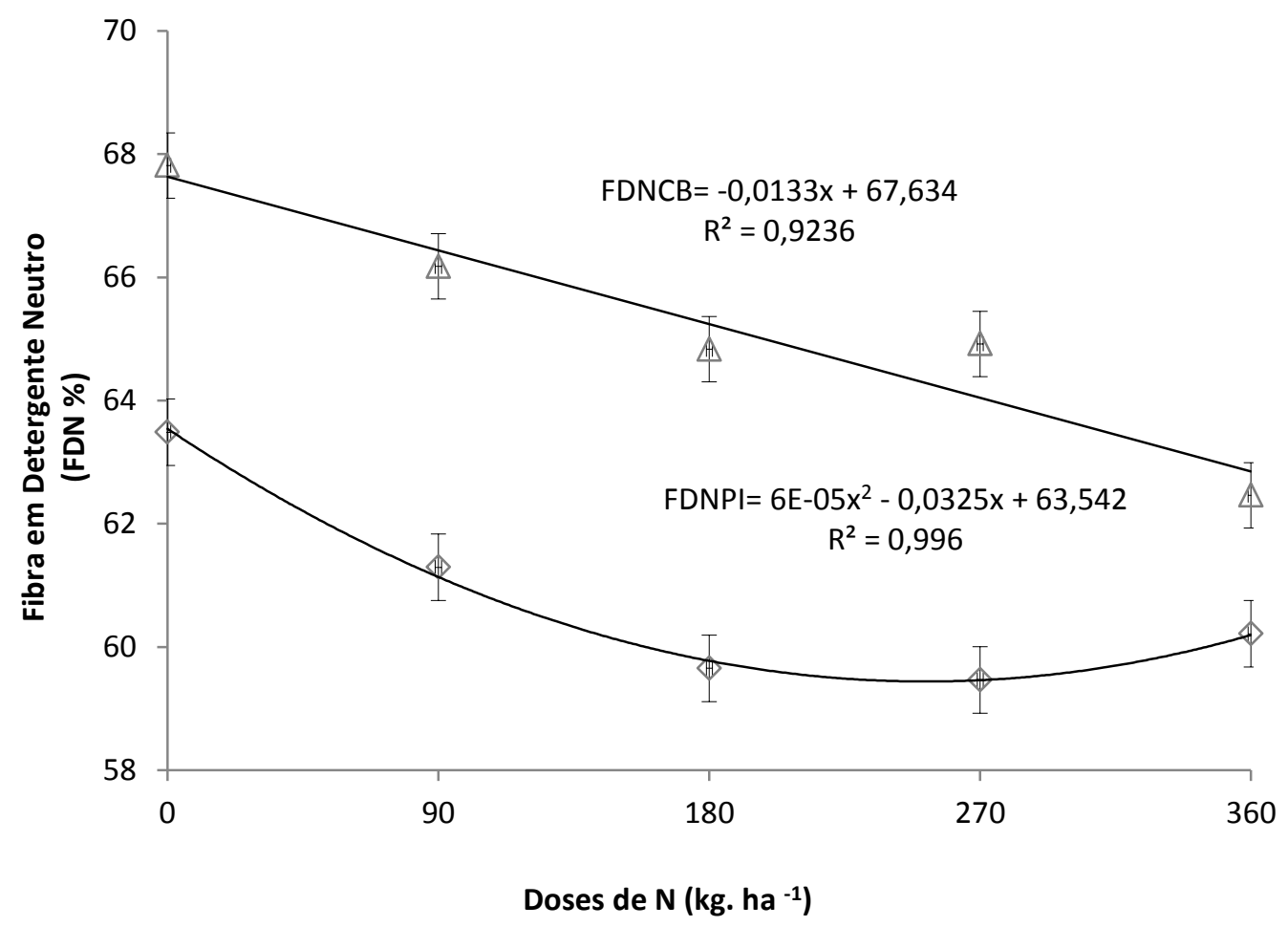

Figura 16. Teores de fibra em detergente neutro de planta inteira e de colmo e bainha de Brachiaria brizantha cv. Marandu adubada com doses de N, considerando as médias dos ciclos de crescimento.

Para planta inteira, resultados similares de FDN foram encontrados por Pinho Costa et al. (2013) em capim-xaraés, que verificaram decréscimos nos teores da

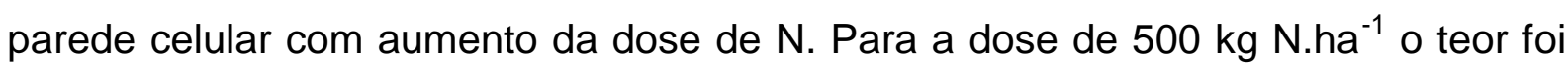
de 62\%. Maranhão et al. (2009), num estudo de doses de $\mathrm{N}$ e espécies de Brachiaria, encontraram para a dose de $225 \mathrm{mg} \cdot \mathrm{dm}^{-3}$ o teor de $59 \%$ de FDN em tecidos da planta inteira de Brachiaria brizantha, o que corrobora com os resultados obtidos neste experimento, sendo o teor de $61 \%$ para a dose de $360 \mathrm{~kg} \mathrm{~N}$.ha ${ }^{-1}$.

Quanto aos teores de FDNCB\%, o comportamento foi linear negativo. Segundo Santos et al. (2009), a aplicação de N resulta em plantas mais altas e com maior número de fitômeros, o que torna necessário que o colmo seja mais rígido e espesso para sustentar o peso da planta. Para isso, o colmo passa a conter maior percentual de tecidos estruturais de sustentação, com parede celular mais espessa, 
tais como o esclerênquima e o xilema. Num outro trabalho, com braquiária diferida e adubada com N, Santos et al. (2010) verificaram para a dose de $120 \mathrm{~kg} \mathrm{~N}^{-h a^{-1}}$ o teor de $82 \%$ de FDN no CB, sendo discrepante do presente experimento, que se observou teor de $63 \%$ para a dose de $360 \mathrm{~kg}^{\mathrm{de} \mathrm{N}} \mathrm{ha}^{-1}$. Justificam os autores que o elevado teor de FDN deveu-se ao crescimento por 70 dias, gerando maior acúmulo de tecidos lignificados.

Os teores de FDNLF\% no $1^{\circ}$ e $2^{\circ}$ ciclos de crescimento diminuíram linearmente com as doses de nitrogênio aplicadas. Para o $3^{\circ}$ ciclo de crescimento houve comportamento quadrático, com diminuição expressiva até a dose de $243 \mathrm{~kg}$ de N.ha ${ }^{-1}$, aumentando posteriormente até a dose de $360 \mathrm{~kg}^{\text {de N.ha- }}{ }^{-1}$ (Figura 17).

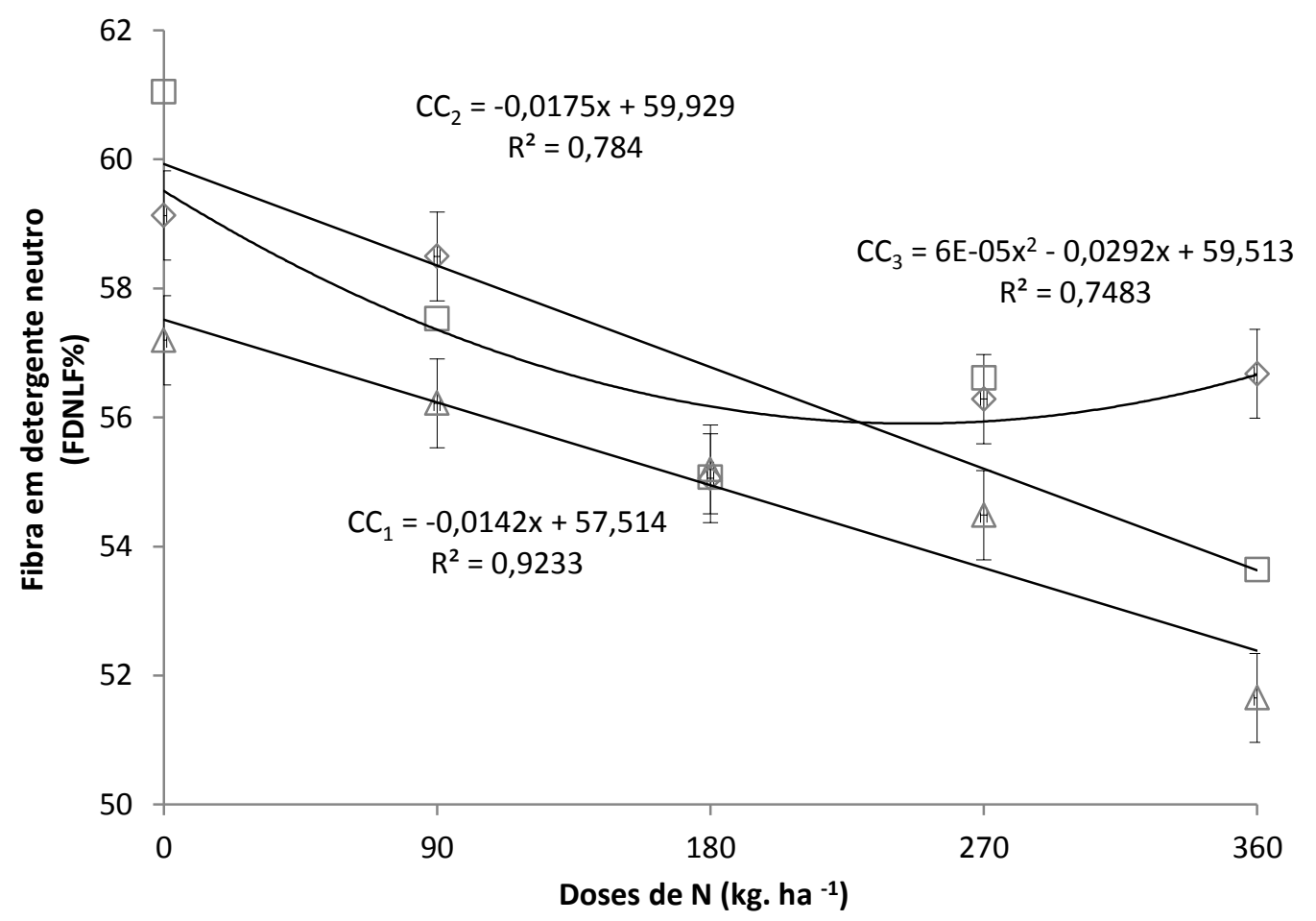

Figura 17. Teores médios de fibra em detergente neutro de lâminas foliares em Brachiaria brizantha cv. Marandu adubada com doses de N, considerando as médias dos ciclos de crescimento.

Santos et al. (2009) verificaram para o capim-braquiária, adubada com 120 kg.ha ${ }^{-1} \mathrm{~N}$ e diferida, o teor de $62 \%$ de FDNLF\% No presente estudo, o teor encontrado foi de $55 \%$, para a dose de $180 \mathrm{~kg}^{-h^{-1}}$ o que demonstra que o incremento de $\mathrm{N}$ pode melhorar a composição química da planta forrageira. 


\subsubsection{Fibra em detergente ácido}

Para os teores de fibra em detergente ácido na planta inteira (FDAPI\%), na lâmina foliar (FDALF\%) e no colmo e bainha (FDACB\%) houve efeito significativo $(\mathrm{P}<0,001)$ para doses de $\mathrm{N}$ e ciclos de crescimento (Tabela 10), não sendo observado efeito da interação $(P>0,001)$.

Tabela 10. Teores médios de fibra em detergente ácido na lamina foliar, planta inteira e colmo e bainha de Brachiaria brizantha cv. Marandu adubada com doses de $\mathrm{N}$, considerando os ciclos de crescimento.

\begin{tabular}{|c|c|c|c|}
\hline \multicolumn{4}{|c|}{ Ciclo de Crescimento } \\
\hline & $\mathbf{1}^{\circ}$ & $2^{\circ}$ & $3^{\circ}$ \\
\hline & Dez/11 a Jan/12 & Jan a Fev/12 & Fev a Mar/12 \\
\hline & \multicolumn{3}{|c|}{ FDA Bruta da Lâmina Foliar } \\
\hline Médias & 31,23 a & $32,16 \mathrm{a}$ & $29,82 \mathrm{~b}$ \\
\hline \multirow{2}{*}{ EPM } & 0,450 & 0,450 & 0,450 \\
\hline & \multicolumn{3}{|c|}{ FDA da Planta Inteira } \\
\hline Médias & $33,10 \mathrm{c}$ & $34,77 \mathrm{~b}$ & $35,22 \mathrm{a}$ \\
\hline \multirow[t]{2}{*}{ EPM } & 0,458 & 0,458 & 0,458 \\
\hline & \multicolumn{3}{|c|}{ FDA do Colmo e Bainha } \\
\hline Médias & $36,11 \mathrm{~b}$ & $37,40 \mathrm{c}$ & $33,30 \mathrm{a}$ \\
\hline EPM & 0,347 & 0,347 & 0,347 \\
\hline
\end{tabular}

Evidenciou-se decréscimo linear no teor de FDA nas frações avaliadas com o acréscimo de $\mathrm{N}$ (Figura 18). A FDA consiste de lignina e de celulose, e tem correlação com digestibilidade, ou seja, quanto maior o teor de FDA da planta forrageira, menor será a digestibilidade (LANA, 2005). 


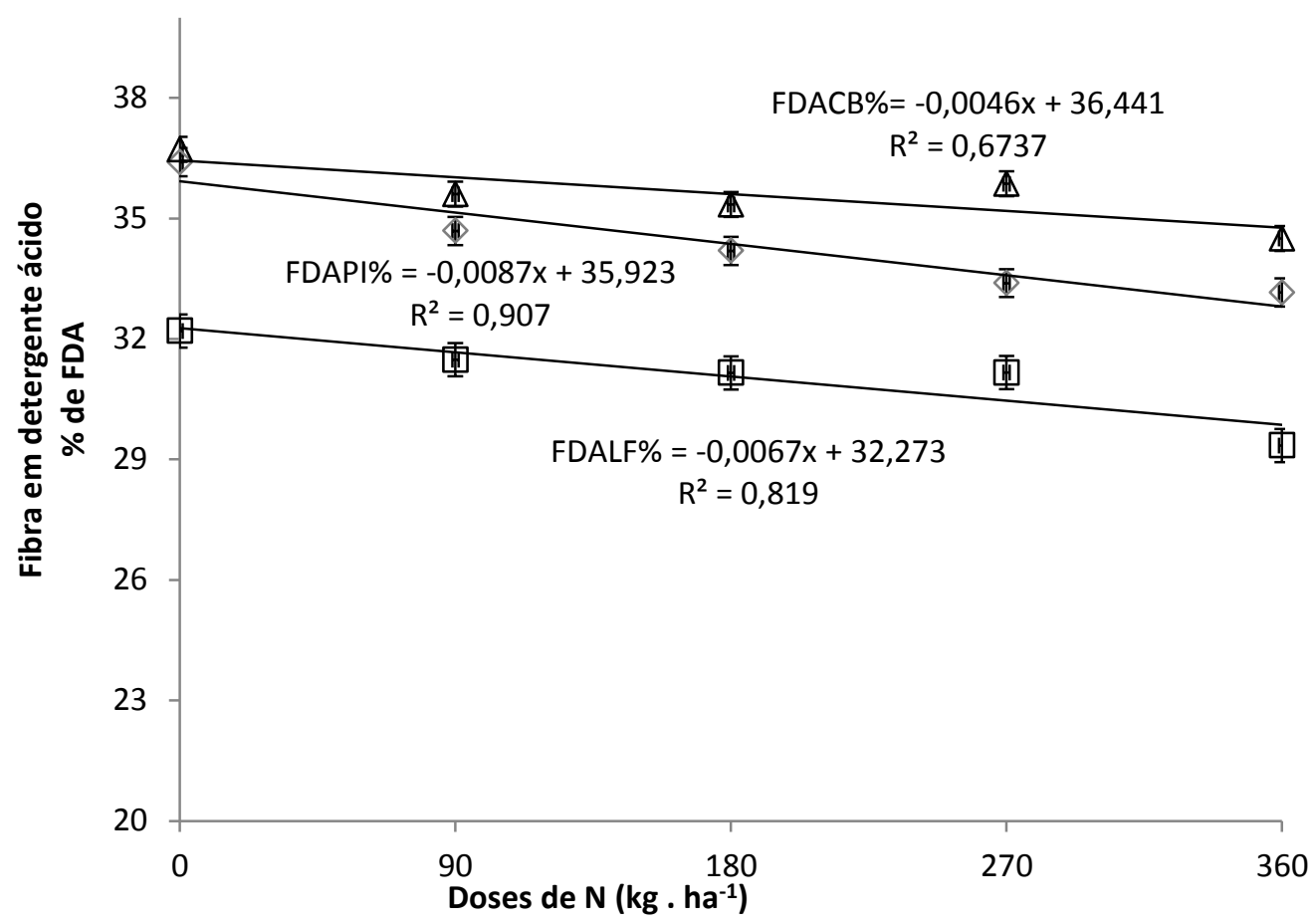

Figura 18. Teores de fibra em detergente ácido da planta, do colmo bainha e da lâmina foliar de Brachiaria brizantha cv. Marandu adubada com doses de N, considerando as médias dos ciclos de crescimento.

Observou-se decréscimo no teor de FDAPI\% da ordem de 34,8 para 29,9\%, considerando a dose de $360 \mathrm{~kg} \mathrm{~N} . h a^{-1}$, sendo corroborado por Pinho Costa et al. (2013) em pesquisa com capim-xaraés e doses de $N$, que verificaram para a dose de $400 \mathrm{~kg} \cdot \mathrm{ha}^{-1}$ de $\mathrm{N}$ a concentração de $31 \%$ de FDA. Já Cecato, Pereira e Jobim (2004), para capim-marandu adubado com a dose de $600 \mathrm{~kg}^{-h^{-1}}$ de N, o teor de $35 \%$ de FDA na PI, durante o verão. Reis et al. (2013), avaliando Brachiaria brizantha cv. Marundu sombreada ou não e sob doses de $\mathrm{N}$, observaram teor de FDA de $35,6 \%$ para a dose de $100 \mathrm{~kg}^{-\mathrm{ha}^{-1}}$, o que corrobora com os resultados obtidos.

De certa forma, os teores de FDA nas partes da planta forrageira tiveram pouca variação, sendo menores nas lâminas foliares. O aumento de tecidos senescentes e de colmo gera uma pastagem de pior valor nutritivo, sendo sempre necessário manter o sistema solo-planta-animal em sintonia, permitindo assim melhor aproveitamento, tanto da pastagem como da adubação em destaque utilizada, transformando isso em maior produção por área. 


\section{CONCLUSÃO}

O capim-marandu, submetido a intenso pastejo por ovinos, depende da adubação nitrogenada em cobertura para sua recuperação, uma vez que este elemento condiciona melhor rebrotação, correlacionada às suas características morfofisiológicas.

O N em cobertura altera positivamente a resposta da planta em produção de massa seca e teores de proteína bruta, com decréscimo na parede celular por efeito de diluição. 


\section{REFERÊNCIAS BIBLIOGRÁFICAS}

AGUIAR, E.M.; BEZERRA NETO, E.; DANTAS, J. A. Efeito da adubação nitrogenada na composição bromatológica do capim-elefante cv. Mott em dois tipos de solos. In: REUNIÃO ANUAL DA SOCIEDADE BRASILEIRA DE ZOOTECNIA. Anais.... Recife: SBZ. 1 CD. 2002

ALEXANDRINO, E. Crescimento e características químicas e morfogênicas da Brachiaria brizantha cv. Marandu submetida a cortes e diferentes doses de nitrogênio. 2000. 132 f. Dissertação (Mestrado) - Universidade Federal de Viçosa, Viçosa, 2000.

ALEXANDRINO, E. et al. Características morfogênicas e estruturais na rebrotação de Brachiaria brizantha cv. Marandu submetida a três doses de nitrogênio. Revista Brasileira de Zootecnia, v.33, n.6, p.1372-1379, 2004.

ALEXANDRINO, E. et al. Características morfogênicas e estruturais da Brachiaria brizantha $\mathrm{cv}$. Marandu submetida a diferentes doses de nitrogênio e frequências de cortes. Acta Scientiarum, v.27, n.01, p.17-24, 2005.

ALEXANDRINO, E.; VAZ, R.G.M.V; SANTOS, A.C. Características da Brachiaria brizantha $\mathrm{cv}$. Marandu durante o seu estabelecimento submetida a diferentes doses de nitrogênio. Bioscience Journal, v.26, n.6, p.886-893, 2010.

ALMEIDA, J.C.R. de. Combinação de doses de fósforo e magnésio na produção e nutrição de duas braquiárias. 1998. 81 f. Dissertação (Mestrado). Escola Superior de Agricultura "Luiz de Queiroz", Universidade de São Paulo, Piracicaba, 1998.

ALVES, J. de S. et al. Características morfológicas e estruturais da Brachiaria decumbens Stapf. submetida a diferentes doses de nitrogênio e volumes de água.

Acta Veterinaria Brasilica, v.2, n.1, p.1-10, 2008.

ANDRADE, R.P. de. Tecnologia de produção de sementes de espécies do gênero Brachiaria. In: PEIXOTO, A.M.; MOURA, J.C. de; FARIA, V.P. de. SIMPÓSIO SOBRE MANEJO DE PASTAGENS. Anais... Piracicaba, FEALQ, Universidade de São Paulo, p.249-266, 1994.

AOAC. Association of official analytical chemists. Official methods of analysis. $13^{\mathrm{a}}$ ed. Washington, 109p, 1980.

BLASER, R.E. Efectdel animal sobre la pasture. In: Paladines, O.L. Empleo de animal sen las investigaticions sobre pasture. Montevideo: IICA. (1-26), 1966.

BONFIM-DA-SILVA, E.M.; MONTEIRO, F.A. Nitrogênio e enxofre em características produtivas do capim-braquiária proveniente de área de pastagem em degradação. Revista Brasileira de Zootecnia, v.35, n.04, p.1289-1297, 2006. 
CABRAL, W.B. et al. Características estruturais e agronômicas da Brachiaria brizantha cv. Xaraés submetida a doses de nitrogênio. Revista Brasileira de Zootecnia, v.41, n.4, p.846-855, 2012.

CARNEVALLI, R.A. et al. Herbage production and grazing losses in Panicum maximum cv. Mombaça under four grazing managements.Tropical Grasslands, v.40, p.165-176, 2006.

CARVALHO, S. et al. Desempenho de cordeiros machos inteiros, machos castrados e fêmeas, alimentados em confinamento.Ciência Rural, v.29, n.1, p.129-133, 1999.

CASAGRANDE, D.R. Características morfogênicas e estruturais do capim-marandu manejado sob pastejo intermitente com diferentes ofertas de forragem.

Revista Brasileira de Zootecnia, v.39, n.10, p.2108-2115, 2010.

CASTAGNARA, D.D. Produção de forragem, características estruturais e eficiência de utilização do nitrogênio em forrageiras tropicais sob adubação nitrogenada. Semina: Ciências Agrárias, v.32, n.4, p.1637-1648, 2011.

CECATO, U. et al. Avaliação de cultivares do gênero Cynodon. In: REUNIÃO ANUAL DA SOCIEDADE BRASILEIRA DE ZOOTECNIA. Anais... Fortaleza, SBZ, p.114-116, 1996.

CECATO, U.; PEREIRA, L.A.F.; JOBIM, C.C. Influência das adubações nitrogenadas e fosfatadas sobre a composição químico-bromatológica do capim-marandu (Brachiaria brizantha (Hochst) StapfcvMarandu). Acta Scientiarum, v.26, n.3, p.409416, 2004.

CHAPMAN, D.F.; LEMAIRE, G. Morphogenetic and structural determinants of plant regrowth after defoliation. In: BAKER, M.J. Grasslands for our world. Wellington, SIR, c.3, p.55-64, 1993.

CORSI, M.; SILVA, R.T de L. Fatores que afetam a composição mineral de plantas forrageiras. In: PASTAGENS: FUNDAMENTOS DA EXPLORAÇÃO RACIONAL. $2^{a}$ ed. Piracicaba, FEALQ/ESALQ, p.65-83, 1994.

CORSI, M.; NASCIMENTO Jr., D. Princípios de fisiologia e morfologia de plantas forrageiras aplicados no manejo de pastagens. In: PEIXOTO, A.M.; MOURA, J.C.; FARIA, V.P. PASTAGENS: FUNDAMENTOS DA EXPLORAÇÃO RACIONAL. Piracicaba, FEALQ, p.15-48, 1994.

CORSI, M.; MENEZES, M.J.T.; GOULART, R.C.D. Manejo do pastejo para altas taxas de lotação. In: SIMPÓSIO GOIANO SOBRE MANEJO E NUTRIÇÃO DE BOVINOS DE CORTE E LEITE. Anais... Goiânia, CNBA, p.299-321, 2004.

COSTA, K.A.P.; FAQUIN, V.; OLIVEIRA, A.P. Doses e fontes de nitrogênio na recuperação de pastagens do capim-marandu. Arquivo Brasileiro de Medicina Veterinária e Zootecnia, v.62, n.1, p.192-199, 2010. 
COSTA, K.A.P. et al. Doses and sources of nitrogen on yield and bromatological composition of xaraés grass. Ciência animal brasileira, v.14, n.3, 2013.

CRAWFORD, N.M.; KAHN, M.L.; LEUSTEK, T.; LONG, S.R. Nitrogen and sulphur. In: BUCHANAN, B.B.; GRUISSEM, W.; JONES, R.L. BIOCHEMISTRY AND MOLECULAR BIOLOGY OF PLANTS. Rockville, American Society of Plant Physiologists, c.16, p.786-849, 2000.

DIFANTE, G.S. et al. Características morfogênicas e estruturais do capim-marandu submetido a combinações de alturas e intervalos de corte. Revista Brasileira de Zootecnia, v.40, n.5, p.955-963, 2011.

DOUGHERTY, C.T.; RHYKERD, C.L.The role of nitrogen in forage-animal production. In: HEATH, M.E.; BARNES, R.F. METCALFE, D.S. FORAGES:

THE SCIENCE OF GRASSLAND AGRICULTURE.5ㄹed. lowa, State University, p.318-325, 1985.

EMBRAPA. Destaque dos principais resultados pesquisa de 1983. Brasília, EMBRAPA-ATA, 88p, 1984.

EUCLIDES, V.B.P. et al. Valor nutritivo da forragem e produção animal em pastagens de Brachiaria brizantha. Pesquisa Agropecuária Brasileira, v.44, p.98106, 2009.

EUCLIDES, V.P.B. et al. Desempenho de novilhos em pastagens de Brachiaria decumbens submetidos a diferentes regimes alimentares. Revista Brasileira de Zootecnia, v.27, p.246-254, 1998.

FAGUNDES, J.L. et al. Acúmulo de forragem em pastos de Brachiaria decumbens adubados com nitrogênio. Pesquisa Agropecuária Brasileira, v.40, n.4, p.397-403, 2005.

FAGUNDES, J.L. et al., Acúmulo de forragem em pastos de Brachiaria decumbens adubados com nitrogênio. Revista Brasileira de Zootecnia, v.35, n.1, p.21-29, 2006.

FONTANELI, R.S.; FONTANELI, R.S. Qualidade e valor nutritivo dos Pastos. In: FORRAGEIRAS PARA INTEGRAÇÃO LAVOURA-PECUÁRIA-FLORESTA NA REGIÃO SUL-BRASILEIRA. 2ªำ ed, Brasília, Embrapa, p.27-49, 2012.

FRICKE, W.; McDONALD, A.J.S.; MATTSON-DJOS, L. Why do leaves and cells leaf of N-limited barley elongate at reduced rates? Planta, v.202, p.522-530, 1997.

GARCEZ NETO, A.G. et al. Respostas morfogênicas e estruturais de Panicum maximum cv. Mombaça sob diferentes níveis de adubação nitrogenada e alturas de corte. Revista Brasileira de Zootecnia, v.32, n.5, p.1890-1900, 2002.

GASTAL, F.; BÉLANGER, G.; LEMAIRE, G. A model of the leaf extension rate of tall fescue in response to nitrogen and temperature. Annals of Botany, v.70, n.2, p.437-442, 1992. 
GASTAL, F., NELSON, C.J. Nitrogen use within the growing leaf blade of tall fescue. Plant Physiology, v.105, p.191-197, 1994.

GHISI, O.M.; PEDREIRA, J.V.S. Características agronômicas das principais Brachiaria spp. In: PEDREIRA, J.V.S.; MEIRELES, N.M.F. ENCONTRO SOBRE CAPINS DO GÊNERO BRACHIARIA. Anais... Nova Odessa, Instituto de Zootecnia, p.97-115, 1987.

GILLET, M.; LEMAIRE, G.; GOSSE, G. Essai d'élaboration d'um schéma global de croissance dês graminées fourragéres. Agronomie, v.4, p.75-82, 1984.

GIMENES, F.M. de A. Ganho de peso e produtividade animal em capim marandu sob pastejo rotativo e adubação nitrogenada. Pesquisa agropecuária brasileira, v.46, n.7, p.751-759, 2011.

GOMIDE, J.A. Morfogênese e análise de crescimento de gramíneas tropicais. In: Gomide, J.A. SIMPÓSIO INTERNACIONAL SOBRE PRODUÇÃO ANIMAL EM PASTEJO. Anais... Viçosa. 471p, 1997.

GOMIDE, C.A.M.; GOMIDE, J.A. Fundamentos e estratégias do manejo de pastagens. In: I SIMPÓSIO DE PRODUÇÃO DE GADO DE CORTE. Anais... Universidade Federal de Viçosa, Viçosa, 1999.

GOMIDE, C.A.M.; GOMIDE, J.A. Morfogênese de cultivares de Panicum maximum Jacq. Revista Brasileira de Zootecnia, v.29, n.2, p.341-348, 2000.

GOMIDE, J.A.; WENDLING, I.J.; BRAS, S.P.; QUADROS, H.B. Consumo e produção de leite de vacas mestiças em pastagem de Brachiaria decumbens manejada sob duas ofertas de forragem. Revista Brasileira de Zootecnia, v.30, n.4, p.1194-1199, 2001.

GOMIDE, C.A.M.; GOMIDE, J.A.; PACIULLO, D.S.C. Morfogênese como ferramenta para o manejo de pastagens. Revista Brasileira de Zootecnia, v.35, p.554-579, 2006.

GRANT, S.A. et al. Comparison of herbage production under continuous stocking and intermittent grazing. Grass and Forage Science, v.43, n.1, p.29-39, 1988.

GRANT, S.A., BERTHARM, G.T. e LYNNETORVELL.Componentes of regrowth in grazed and cut Lolium perene swards.Grass and Forage Science, v.36, p.155-168, 1981.

HODGSON, J. Grazing Management: Science into practice. New York: John Wiley \& Sons, p.203, 1990.

HODGSON, J.; DA SILVA, S.C. Options in tropical pasture management. In: Reunião Anual da Sociedade Brasileira de Zootecnia, 39.; SIMPÓSIO

INTERNACIONAL DE FORRAGICULTURA, Recife: SBZ, 2002. 
HORST, G.L., NELSON, C.J. ASAY, K. H. Relationship of leaf elongation to forage yield of tall fescue genotypes. Crop Science, v.18, n.5, p.715-719, 1978.

JONES, R.J., NELSON, C.J. SLEPER, D.A. Seedling selection for morphological characters associated with yield of tall fescue. Crop Science, v.19, n.5, p.631-634, 1979.

KÖPPEN, W.; GEIGER, R. Klimate der Erde. Gotha: Verlag Justus Perthes. 1928.

LANA, R.P. Nutrição e alimentação animal (mitos e realidades). Universidade Federal de Viçosa, Viçosa, 344p, 2005.

LEMAIRE, G.; CHAPMAN, D. Tissue flows in grazed plant communities. In: HODGSON, J., ILLIUS, A.W. THE ECOLOGY AND MANAGEMENT OF GRAZING SYSTEMS. London: CAB International, p.3-36, 1996.

LEMAIRE, G. The physiology of grass growth under grazing: Tissue turnover. In: SIMPÓSIO INTERNACIONAL SOBRE PRODUÇÃO ANIMAL EM PASTEJO, Anais... Universidade Federal de Viçosa, Viçosa, p.117-144, 1997.

LUGÃO, S.M.B. et al. Avaliação econômica da adubação nitrogenada em pastagens de Panicum maximum Jacq. (acesso BRA-006998). In: REUNIÃO ANUAL DA SOCIEDADE BRASILEIRA DE ZOOTECNIA. Anais...Piracicaba, SBZ, p.261-263, 2001.

MAcADAM, J.W.; VOLENEC, J.J.; NELSON, C.J. Effects of nitrogen on mesophyll cell division and epidermal cell elongation in tall fescue leaf blades. Plant Physiology, v.89, p. 549-556, 1989.

MALAVOLTA, E. Manual de nutrição mineral de plantas. São Paulo: Ceres, 638p, 2006.

MARANHÃO, C.M.A. et al. Produção e composição bromatológica de duas cultivares de braquiária adubadas com nitrogênio e sua relação com o índice SPAD. Acta Scientiarum, v.31, n.2, p.117-122, 2009.

MARTUSCELLO, J.A.; FONSECA, D.M.; NASCIMENTO Jr., D. et al. Características morfogênicas e estruturais do capim-xaraés submetido à adubação nitrogenada e desfolhação. Revista Brasileira de Zootecnia, v.34, n.5, p.1475-1482, 2005.

MAYA, F.L.A. Produtividade e viabilidade econômica da recria e engorda de bovinos em pastagens adubadas intensivamente com e sem uso da irrigação. 2003. 81 f. Dissertação (Mestrado) - Universidade de São Paulo, Piracicaba, 2003.

MERTENS, D.R. Regulation of forage intake. In: FAHEY JR., G.C. Forage quality, evaluation and utilization. Winsconsin, American Society of Agronomy, 1994. 
MONTEIRO, F.A. Adubação para estabelecimento e manutenção de capim-elefante. In: SIMPÓSIO SOBRE CAPIM-ELEFANTE, Anais... Coronel Pacheco, EMBRAPACNPGL, p.47-62, 1994.

MORIKAWA, C.K. Limitações nutricionais para o Andropogon (Andropogon gayanus) e braquiarão (Brachiariabrizantha) em latossolo da região dos campos das vertentes. 1993. 163 f. Dissertação (Mestrado) - Escola Superior de Agricultura de Lavras, Lavras, 1993.

MYERS, R.J.K.; ROBBINS, G.B. Sustaining productive pastures in the tropics. Maintaining productives own grasspastures. Tropical Grasslands, v.25, p.104-110, 1991.

NABINGER, C.; MEDEIROS, R.B. Produção de sementes de Panicum maximum Jacq. In: SIMPÓSIO SOBRE O MANEJO DE PASTAGENS. Anais... Piracicaba, Fundação de Estudos Agrários Luiz de Queiroz, p.59-128, 1995.

NABINGER, C. Princípios da exploração intensiva de pastagens. In: PEIXOTO, A.M.; MOURA, J.C. de; FARIA, V.P. de. In: SIMPOSIO SOBRE MANEJO DE PASTAGENS. Anais... Piracicaba, FEALQ, p.15-96, 1997.

NABINGER, C.; PONTES, L.S. Morfogênese de plantas forrageiras e estrutura do pasto. In: REUNIÃO ANUAL DA SOCIEDADE BRASILEIRA DE ZOOTECNIA. Anais... Piracicaba, FEALQ, p.755-771, 2001.

NABINGER, C. Manejo da desfolha In: SIMPÓSIO SOBRE MANEJO DA PASTAGEM. Anais... Piracicaba, Escola Superior de Agricultura "Luiz de Queiroz", p.192-210, 2001.

NASCIMENTO Jr., D. Fundamentos para o manejo de pastagens: evolução e atualidade. In: OBEID, J.A., PEREIRA, O.G., FONSECA, D.M., NASCIMENTO Jr., D. SIMPÓSIO SOBRE MANEJO ESTRATÉGICO DA PASTAGEM. Anais... Viçosa, Universidade Federal de Viçosa, p.149-196, 2002.

NELSON, C.J., ASAY, K.H., SLEPER, D.A. Mechanisms of canopy development of tall fescue genotypes.Crop Science, v.17, n.3, p.449-452, 1977.

NUNES, S.G. et al. Brachiaria brizanthacv. Marandu. Campo Grande: EMBRAPA, CNPGC, 2 ed., p.31, 1984.

OLIVEIRA, P.P.A. et al. Fertilização com $\mathrm{N}$ e S na recuperação de pastagem de Brachiaria brizantha cv. Marandu em Neossolo Quartzarênico. Revista Brasileira de Zootecnia, v.34, p.1121-1129, 2005.

ORRICO Jr. M.A.P. et al. Características morfogênicas do capim-piatã submetido à adubação com efluentes de abatedouro avícola. Ciência Rural, v.43, n.1, p.158-163, 2013. 
PACIULLO, D.S.C.; GOMIDE, J.A.; RIBEIRO, K.G. Adubação nitrogenada do capimelefante cv. Mott. 1. Rendimento forrageiro e características morfofisiológicas ao atingir 80 e $120 \mathrm{~cm}$ de altura. Revista Brasileira de Zootecnia, v.27, p.1069-1075, 1998.

PAULA, C.C.L. et al. Acúmulo de forragem, características morfogênicas e estruturais do capim-marandu sob alturas de pastejo. Ciência Rural, v.42, n.11, p.2059-2065, 2012.

PARSONS, A.J.; PENNING, P.D. The effect of the duration of regrowth on photosynthesis, leaf death and the average rate of growth in a rotationally grazed sward. Grass and Forage Science, v.43, n.1, p.15-27, 1988.

PINTO, J.C. et al. Produção de matéria seca e relação folha/caule de gramíneas forrageiras tropicais, cultivada em vaso, com duas doses de nitrogênio. Revista Brasileira de Zootecnia, v.23, n.3, p.313-326, 1994.

PINTO, L.F.M.; DA SILVA, S.C.; SBRISSIA, A.F. et al. Dinâmica do acúmulo de matéria seca em pastagens de Tifton 85 sob pastejo. Scientia Agricola, v.58, p.439447, 2001.

PRIMAVESI, A.C.; et al. Nutrientes fitomassa de capim-Marandu em função de fontes e doses de nitrogênio. Ciência e Agrotecnologia, v.30, n.3, p.562-568, 2006.

QUEIROZ NETO, F.; MARTHA Jr., G.B.; PENATI, M.A. Impacto increasing nitrogen fertizer rates uponna irrigated Tanzânia grasspasture. Dry matter yield. (compact disc). In: INTERNATIONAL GRASSLAND CONGRESS. Proceedings... São Pedro: FEALQ, 2001

RAIJ, B. V. Fertilidade de solo e adubação. Piracicaba: Ceres, Patafós, p. 343, 1991.

RAYMAN, P.R. Minha experiência com Brachiaria brizantha. Campo Grande, Rayman's Seeds Sementes de Pastagens Tropicais, 1983. 3p.

REIS, R.A.; RODRIGUES, L.R.A. Valor nutritivo de plantas forrageiras. Jaboticabal: Universidade Estadual Paulista, 1993.

REIS, G.L. et al. Produção e composição bromatológica do capim-marandu, sob diferentes percentuais de sombreamento e doses de nitrogênio. Bioscience Journal, v.29, s.1, p.1606-1615, 2013.

RIBEIRO, O.L. Características morfogênicas, produtivas e desempenho animal em capim-Tanzânia adubado ou consorciado com estilos antes em lotação contínua. 2010. 77 f. Tese (Doutorado) - Universidade Estadual de Maringá, Maringá, 2010.

RODRIGUES, M.G.; SANTOS, A.R. Efeito da adubação com resíduo orgânico em Latossolo Amarelo Coeso na produção da Brachiaria decumbens stapf. e no acúmulo de metais pesados. Magistra, v.14, n.2, 2002. 
RODRIGUES, R.C. et al. Produção de massa seca, relação folha/colmo e alguns índices de crescimento do Brachiaria brizantha cv. Xaraés cultivado com a combinação de doses de nitrogênio e potássio. Revista Brasileira Zootecnia, v.37, n.3, p.394-400, 2008.

SANTOS, E.D.G. et al. Avaliação de pastagem diferida de Brachiaria decumbens Stapf.:1. Características químico-bromatológicas da forragem durante a seca. Revista Brasileira de Zootecnia, v.33, n.1, p.203-213, 2004.

SANTOS, M.E.R. et al. Capim-braquiária diferido e adubado com nitrogênio: produção e características da forragem. Revista Brasileira de Zootecnia, v.38, n.4, p.650-656, 2009.

SANTOS, M.E.R. et al. Valor nutritivo de perfilhos e componentes morfológicos em pastos de capim-braquiária diferidos e adubados com nitrogênio. Revista Brasileira de Zootecnia, v.39, n.9, p.1919-1927, 2010.

SAS Institute Inc. 2008.SAS/STAT® 9.2 User's Guide. Cary, NC: SAS Institute Inc. 2008.

SBRISSIA, A.F.; Da SILVA, S.C. O ecossistema de pastagens e a produção animal. In: REUNIÃO DA SOCIEDADE BRASILEIRA DE ZOOTECNIA. Anais... Piracicaba, SP, SBZ, p.731-754, 2001.

SCHNYDER, R.H. et al. An integrated view of $\mathbf{c}$ and $\mathbf{n}$ uses in leaf growth zones of defoliated grasses. In: LEMAIRE, G.; HODGSON, J.; MORAES, A.; CARVALHO, P.C.F.; NABINGER, C. GRASSLAND ECOPHYSIOLOGY AND GRAZING ECOLOGY. CABI Publishing, CAB International, Wallingford, Oxon OX10 8DE, UK, p.41-60.2000.

SILVA, C.C.F. et al. Características morfogênicas e estruturais de duas espécies de braquiária adubadas com diferentes doses de nitrogênio. Revista Brasileira Zootecnia, v.38, n.4, p.657-661, 2009.

SILVA, D.R.G. Doses e fontes de nitrogênio na recuperação das características estruturais e produtivas do capim-marandu. Revista Ciência Agronômica, v.44, n.1, p.184-191, 2013.

SKERMAN, P.J.; RIVEIROS, F. Gramíneas tropicales. Roma: FAO, 832 p., 1992.

SKINNER, R.H.; NELSON, C.J. Elongation of the grass leaf and its relationship to the phyllochron. Crop Science, v.35, p.4-10, 1995.

SOARES FILHO, C.V. Tratamento físico-mecânico, correção e adubação para recuperação de pastagens. In: ENCONTRO SOBRE RECUPERAÇÃO DE PASTAGENS. Anais... Instituto de zootecnia, Nova Odessa, p.79-117, 1993.

VAN SOEST, P.J. Nutritional ecology of the ruminant. $2^{\mathrm{a}}$ ed. Ithaca: Cornell, $476 p, 1994$. 
VICENT-CHANDLER.J. Intensive manegemente in Puerto Rico. Revista Brasileira de Zootecnia, v.2, n.2, p.173-215, 1973.

VILELA, D.; ALVIM, M.J. Manejo de pastagens do gênero Cynodon: introdução, caracterização e evolução do uso no Brasil. In: SIMPÓSIO SOBRE MANEJO DA PASTAGEM, 1998,

WERNER, J.C. Adubação de pastagens. Nova Odessa, Instituto de Zootecnia, Boletim Técnico18, 49p, 1986.

WILHELM, W.W.; McMASTER, G.S. Importance of the phyllochron in studying development and growth in grasses.Crop Science, v.35, n.1, p.1-3, 1995.

WHITEMAN, P.C. Tropical pasture science.New York, Oxford University Press, $392 \mathrm{p}, 1980$.

WHITNEI, A.S. Grow of kikuyu grass (Pennisitum clandistinun) under clipping. Effect of nitrogen fertilizion, custting interval and season on yelds and forage characteristics.Agronomy Journal, v.66, p.281-287, 1974.

WOOD, C.W. et al. Nutrient management on pasture and Hayland. In: Nelson, C.J. Conservation outcames from Pastureland and Hayland Practices. Allen Press. Lawrence, Kansas, p.257-315, 2012. 